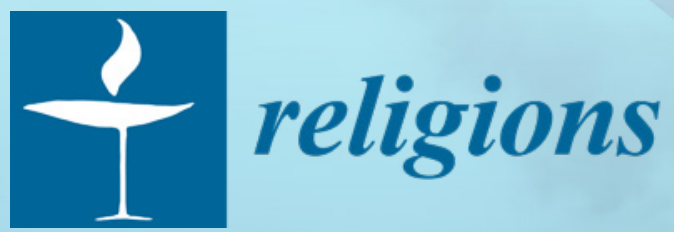

\title{
New Developments in Christianity
}

in China

Edited by

Francis K. G. Lim

Printed Edition of the Special Issue Published in Religions 
New Developments in Christianity in China 



\section{New Developments in Christianity in China}

Special Issue Editor

Francis K. G. Lim 
Special Issue Editor

Francis K. G. Lim

Nanyang Technological University

Singapore

Editorial Office

MDPI

St. Alban-Anlage 66

4052 Basel, Switzerland

This is a reprint of articles from the Special Issue published online in the open access journal Religions (ISSN 2077-1444) (available at: https://www.mdpi.com/journal/religions/special_issues/china).

For citation purposes, cite each article independently as indicated on the article page online and as indicated below:

LastName, A.A.; LastName, B.B.; LastName, C.C. Article Title. Journal Name Year, Article Number, Page Range.

ISBN 978-3-03928-724-6 (Pbk)

ISBN 978-3-03928-725-3 (PDF)

Cover image courtesy of Francis K. G. Lim.

(C) 2020 by the authors. Articles in this book are Open Access and distributed under the Creative Commons Attribution (CC BY) license, which allows users to download, copy and build upon published articles, as long as the author and publisher are properly credited, which ensures maximum dissemination and a wider impact of our publications.

The book as a whole is distributed by MDPI under the terms and conditions of the Creative Commons license CC BY-NC-ND. 


\section{Contents}

About the Special Issue Editor . . . . . . . . . . . . . . . . . . . vii

\section{Francis K. G. Lim}

New Developments in Christianity in China

Reprinted from: Religions 2020, 11, 30, doi:10.3390/rel11010030 . . . . . . . . . . . . . . 1

Magdaléna Masláková and Anežka Satorová

The Catholic Church in Contemporary China: How Does the New Regulation on Religious Affairs Influence the Catholic Church?

Reprinted from: Religions 2019, 10,446, doi:10.3390/rel10070446 . . . . . . . . . . . . . . . .

\section{Nanlai Cao}

A Sinicized World Religion?: Chinese Christianity at the Contemporary Moment of Globalization

Reprinted from: Religions 2019, 10,459, doi:10.3390/rel10080459 . . . . . . . . . . . . . . . 25

\section{Jie Kang}

The Rise of Calvinist Christianity in Urbanising China

Reprinted from: Religions 2019, 10,481, doi:10.3390/rel10080481 . . . . . . . . . . . . . . . 37

Michel Chambon

Chinese Catholic Nuns and the Organization of Religious Life in Contemporary China

Reprinted from: Religions 2019, 10,447, doi:10.3390/rel10070447 . . . . . . . . . . . . . . . . . .

\section{Carsten Vala and Jianbo Huang}

Online and Offline Religion in China: A Protestant WeChat "Alter-Public" through the Bible Handcopying Movement

Reprinted from: Religions 2019, 10,561, doi:10.3390/rel10100561 . . . . . . . . . . . . . . . . 67

Steve Wai Lung Cheung and Khun Eng Kuah

Being Christian through External Giving

Reprinted from: Religions 2019, 10,529, doi:10.3390/rel10090529 . . . . . . . . . . . . . . . . 85

\section{Francis K. G. Lim}

"Serving the Lord": Christianity, Work, and Social Engagement in China Reprinted from: Religions 2019, 10, 196, doi:10.3390/rel10030196 . . . . . . . . . . . . . . . . . . 101 



\section{About the Special Issue Editor}

Francis K. G. Lim is Associate Professor at the School of Social Sciences, Nanyang Technological University. His current research interest focuses on religion in various Asian cultures and societies. His latest book project examines how Christians seek to transform mainland China through the workplace, social media, and community development work. He is the author of Imagining the Good Life: Negotiating Culture and Development in Nepal Himalaya (Brill 2008), co-editor of Christianity and the State in Asia: Complicity and Conflict (Routledge 2009), and editor of Mediating Piety: Technology and Religion in Contemporary Asia (Brill 2009) and Christianity in Contemporary China: Socio-cultural Perspectives (Routledge 2013). 



\title{
Editorial \\ New Developments in Christianity in China
}

\author{
Francis K. G. Lim \\ Sociology, School of Social Sciences, Nanyang Technological University, Singapore 639798, Singapore; \\ FKGLIM@NTU.EDU.SG
}

Received: 19 December 2019; Accepted: 31 December 2019; Published: 6 January 2020

Christianity's rapid expansion in China in recent years has attracted much attention from scholars, China policymakers, local and international media, and the wider public. Many Christian groups throughout the country are harnessing the tremendous power of new media such as the internet and mobile apps to share religious messages, participate in rituals, access information, create online communities, and to evangelize. As communications infrastructure continues to improve across China and with the country's deepening linkages with the rest of the world, Chinese Christian networks are spreading both within and outside the country. These networks link and crisscross at multiple scales and localities in China as well as deepen interactions with overseas Christians and global Christianity. Chinese Christians have also begun exerting their influence outside China through activities such proselytism, charity work, and development projects. Debates, contestations and negotiations have proceeded on issues such as the divide between "official" and "unofficial" churches; the affinity between Christianity and Chinese culture; whether China is becoming Christianized (and over the exact number of Christians); the influence of foreign Christian groups; and the role of Christianity in international politics. Further, the close ties between some Christian groups in China and those based overseas (such as American and South Korean Christian organizations actively cultivating ties in China), and the Chinese Catholics' complicated relationship with the Vatican, have contributed to the party-state's intense suspicion over foreign interference in the country's religious and political affairs.

Protestant Christianity in particular has attracted huge numbers of new believers in both rural and urban areas. As Lian Xi notes in his book, Redeemed by Fire, one important reason is the transformation of Christianity "from an alien faith preached and presided over by Western missionaries into an indigenous religion of the masses" (Lian 2010, p. 2). According to Sun (2017), the main reason behind the rise of Protestantism in Post-Mao China is the intricate interplay between state actions and the institutional features of Protestantism. These institutional features comprise of zero-sum evangelism, congregational structure, insistence on church autonomy, a polycephalous structure, glorification of martyrdom, and global support network. In themselves, these institutional features are unable to fully explain the rapid expansion of Protestantism in China. The role of the state, specifically the unintended effects of its actions during Mao and post-Mao eras, shaped the crucial socio-political context conducive for Protestantism to gain a stronger foothold in China. On the one hand, a series of state's anti-superstition and anti-feudalism campaigns between 1950s and late 70s undermined the traditional normative and institutional orders of Chinese popular religion that had historically strongly opposed Christianity at the grassroots level. On the other hand, the state's pursuit of market-oriented economic development during the post-Mao era has resulted in relative weakening of political control in the local society. Local officials were much more interested in demonstrating their capabilities in spurring economic development than controlling religious activities. In addition, the understaffing of relevant bureaucracies such as the local Religious Affairs Bureau meant that implementation of religious policies was not effectively carried out. According to Sun, it is a combination of the institutional features of Protestantism and the (unintended) state actions that has resulted in the rapid rise of Protestantism over the past four decades.

On the legal front, one of the most significant developments with regard to the party-state's regulation of religion is the promulgation of a revised Regulation on Religious Affairs in 2008. 
Comprising of 9 chapters and 77 articles, this document covers a broad range of religious activities, including fund raising, the use of online platforms, and relationships with foreign entities. The new Regulation and its impact on the state-supported China Catholic Patriotic Church is the subject of Magdaléna Masláková and Anežka Satorová's contribution to this journal special issue. The authors interviewed members of the clergy mainly from the Zhejiang province with the aims of soliciting their views on how their work and relationship with the authorities have been impacted by the new regulations. Some of the interviewees readily acknowledge that the open Church has little choice but to follow the leadership of the Chinese Communist Party; they consider the Regulation as part of the party-state's broader attempt to "sinicize religions". More specifically, it is the direct result of President Xi Jinping's attempt to further bend religion in China to Chinese-style socialism under the direction of the Communist Party. For the religious leaders, including those in the official Catholic Church, this latest development represents a decades' old effort by the party-state to control religion, and many of those interviewed already have a stock of strategies to deal with deal with it. At the everyday level, local Catholic clergy are mostly "playing according to the rules" so as continue to cultivate good relations with local governments, avoid the suspicion of authorities, and to protect their own communities. The Catholic clergy seek to foster a public image of patriotic Christians while surreptitiously safeguarding their own religious agenda.

Meanwhile, as China opens up to the world from the early 1980s onwards, even village religious life in seemingly remotes areas has been inexorably shaped by translocal and transnational processes. In the book, God Above Ground, Lozada (2001) examines how the church of "Little Rome", in a predominantly Hakka village in Guangdong province, has been rebuilt with flows of funds from the Hakka diaspora. In the villagers' desire to pursue 'development' and 'modernity' in the new market economy, Catholic rituals have played a significant role in integrating other aspects of the villagers' engagement with transnational processes such as economic migration, consumption and nation-state building, part of their interpretation and experience of being 'modern' in the contemporary world. In a similar vein, Cao Nanlai's contribution in this special issue seeks to go beyond the current scholarship that tends to focus on church-state relations to suggest a transnational framework for studying Chinese Christianity in the context of globalized networks and flows. In "A Sinicized World Religion? Chinese Christianity at the Contemporary Moment of Globalization", Cao wants to correct a "Western-centric view on Christianity's one-way penetration of Chinese society and culture" through an empirical study of how a Sinicized version of Christianity is spreading in the Schengen region of Europe, mainly via the extensive business and social networks of Chinese traders and merchants. In this article, Cao argues that Chinese Christianity is an emergent form of world religion and identifies diasporic Chinese Christians as agents of religious globalization.

These days, many Chinese people no longer consider Christianity a "foreign" religion and a tool for Western imperialistic expansion, but as a prestigious religion that symbolizes modernity and cosmopolitanism. Yang's (2005) study of conversion to Christianity in urban China finds that the crucial contexts for the rising numbers of new converts in the 1990s in the cities were China's increasing embrace of the globalizing market economy under circumstances of tight political control and suppression of dissent. This combination of circumstances prompted some urban residents disenchanted with Communist ideology to turn to Christianity as a viable source of religious and moral certitude. Many of these believers also viewed Christianity positively as signifying liberalism, democracy, modernity and cosmopolitanism. New Christian converts, especially in the cities, increasingly hail from the elite strata of Chinese society consisting of successful businesspeople, university students, and professionals (Gao 2005; Cao 2011). Their accumulated social, cultural and economic capital in turn empowered them with greater organizational and mobilization capacities in the pursuit of religious aims. In the cities, many independent Christian groups are renting commercial premises for conducting their religious activities, even when this is often illegal. Christians' increasing willingness to take an assertive negotiating position vis-à-vis the authorities was clearly seen in 2001, when the Shouwang church 
members, after being forced to vacate their original premises, held outdoor services and strove to stake out a prominent presence in the public sphere.

Jie Kang's article for this special issue, "The Rise of Calvinist Christianity in Urbanising China", examines the spread of Calvinism as an integral part of China's urbanization process and resulting from the rising numbers of high-educated Chinese in the cities. In spite of the state's close monitoring of and restrictions on independent churches, Kang's study illustrates the important role played by overseas Chinese and foreign (especially Korean) missionaries in the dissemination of Reformed theology in China. As it localizes, Calvinism has taken on certain Chinese features. First, unlike the early Calvinists in Europe, Chinese Calvinists tend to express certainty of their salvation, regarding "their lives as predestined by God alone". In addition, believers are disciplined and generally obedient to their pastors. Thirdly, seeing nothing wrong in combining religion and business, some Calvinists have become entrepreneurs in the business of religious tourism. Lastly, Chinese Calvinism lays strong emphasis on morality and personal piety while discouraging overt political expressions. Kang's paper thus further adds to our overall picture of the urban (independent) Church which is showing vitality and increasing confidence. At the same time, it is also experiencing incessant fragmentation as members break away from existing groups due to personal, institutional and theological disagreements.

In contrast, detailed anthropological studies of Christianity in the rural areas paint a more ambivalent picture. Over the last two decades, many Christian village communities have witnessed the re-opening of local churches and much greater freedom to practice their faith (e.g., Liang 1999; Lim 2009). In his research in Wu village in the Gansu province, Huang (2012) finds that both official Catholic and Protestant churches had benefitted initially from the reforms and new religious policies in the 1980s. However, since the late 1990s, the village churches have experienced a marked decline, precisely because of the village's deepening integration into translocal and transnational flows. One of the most important factors behind the decline is economic migration, as the young in the village, especially men, join the millions of migrants from other parts of China moving to the cities in search of jobs and a better life. The result has been the gradual hollowing out of the rural Christian community. According to Huang's informants, there were almost no new converts in the five years since 1997, and the churches these days are no longer as "vibrant" as they used to be. Huang observes that the numbers of people attending church events are always far lower than what the church leaders claimed to be the size of the local Christian community. The village church seems like an "Old Folks' club" or a "Women's club".

Michel Chambon's article looks at a group of Christians which have not been the subject of much research in the recent scholarship on Christianity in China-the Catholic nuns. Based on 18 months of ethnographic fieldwork among Catholic communities in Nanping and extensive interviews with Catholic nuns and other clergy members in China and elsewhere, Chambon provides us with a fascinating account of how Catholic nuns seek to model themselves and their religious works on two distinct modes of Catholic religious life, that of the consecrated virgins (or beatas) and the missionary congregations. Besides drawing on these two models of religious life for inspiration, the congregations and lifestyle of Catholic nuns in China are also shaped by their encounter with various local and foreign Church actors and China's specific socio-historical realities such as religious persecutions and economic change. Resilient, adaptive and creative, Chinese Catholic nuns have forged a path that does not fully conform to what the universal Church expects them to embark on. At the same time, they continue to rely on the rich traditions and historical experiences of the Catholic Church to overcome challenges in their pursuit of their religious calling in an often hostile and unpredictable environments.

One of the most remarkable social trends in China in recent years is the explosion of mobile internet and social media usage. This can be seen by the widespread use of the micro-blog platform Weibo, the mobile chat app WeChat, and video sharing site Tudou, among many others. In 2017, WeChat alone has around 494 million individual users in China, and hit one billion user accounts worldwide (Financial Times 2018). In addition to its social messaging function, WeChat is also a popular platform for e-commerce, mobile payments, and blogs. Recently, there has been increasing 
scholarly attention on religion and media in mainland China, Taiwan and Hong Kong (Travagnin 2017; Lim and Sng). Carsten Vala and Jianbo Huang's contribution presents a case study of the offline Bible handcopying movement that had been initiated online via the WeChat app. As the authors point out, studies of digital religion are predominantly carried out in liberal, democratic countries with developed economies. The picture of digital religion presented through such studies tend to show how new media technologies have enabled the formation of innovative religious expressions, new communities, and new theologies. These technologies also allow existing religious groups to reformulate and reconstitute their relationships with the wider public and to promote their own versions of orthodoxy. Some scholars have thus argued that digital religion is an example of a new public sphere that allows for discussion, debates and contestations between different social groups, state and non-state actors concerned with religious matters. Vala and Huang argue that in an authoritarian context like China's, digital religion does not constitute a public sphere where debates and contestations with various authorities may occur. Rather, Chinese Protestants' religious engagement through the WeChat online space represents an 'alter-public', a space where state censorship or fear of censorship "encourages the WeChat group organizers to cultivate a public that is not explicitly counter to the ruling authorities and its official agenda." Protestant participants in this alter-public assiduously avoid open and direct confrontation with the state while cultivating multiple identities as both loyal Chinese citizens and pious Christians.

While Vala and Huang's study examines the cultivation of Christian piety through the Bible handcopying movement, Steve Cheung and Khun Eng Kuah approach the matter through an ethnographic study in Hong Kong of Christians' understanding and practice of external giving, i.e., giving outside the church. Taking the rational choice approach as a point of departure, Cheung and Kuah argue that external giving should not be understood as primarily a rational choice decision. Their ethnographic data and interviews with respondents show that giving is a "dynamic and transformative act" that allows individual believers to "reflect upon and enact their sacred selves". This cultivation of the Christian sacred self is regarded as enacting the work of Jesus Christ and an expression of God's love to the needy. In short, the interiority of Christian piety is inextricably intertwined with the exteriority of social concerns and engagement. Ultimately, Christian external giving facilitates the construction of a tripartite sacred moral economy involving three key actors, namely, the Christian givers, God and the recipients of the giving, with their social relationships underpinned more by moral norms and expectations than economic considerations.

Continuing with the topic of Christianity and social change, my article, "'Serving the Lord': Christianity, Work and Social Engagement in China", suggests that we need to look beyond overt religious mobilization and civil society activism to better understand how Christianity manages to spread in China and its potential to be a force for social change in the country. This is especially pertinent in the current context of ever tighter state regulations and deepening political suspicion over religious groups, especially those with close ties with their co-religionists overseas. I examine a domain which is not usually conceptualized as belonging to civil society, that of the workplace. While existing scholarship tends to focus on the activities of Chinese Christian entrepreneurs or bosses, I analyze the motivation, beliefs and activities of Christian professionals employed in non-Christian workplaces. Using the frameworks of everyday religion and unobtrusive social engagement, I demonstrate how these Christian employees practice their religious faith in the secular workplace, subtly change the workplace culture, and ultimately engage in a kind of unobtrusive religious social engagement. Many of them do not see a clear boundary between a 'secular' workplace and a separate domain of religion. Just as the respondents in Cheung and Kuah's article who tend to regard the act of giving as enabling them to live out their faith and be truly Christian, the mainly Evangelical Protestant employees in my study interpret work as a kind of service to God that necessarily entails spreading Christian values in the workplace and to their colleagues. The ultimate goal is the moral transformation of China via Christianity. 
Given the tremendous diversity of the Christian experience in contemporary China, it would be prudent to avoid making sweeping generalizations about the faith in China. One thing is clear, though: just like Islam, Buddhism, Daoism, folk religion, and other forms of religiosity, Christianity over the past couple of decades has experienced an efflorescence of such a degree that would have been unimaginable at the tail-end of the Maoist era. One explanation is that the government's policies on religion have been constantly evolving, and unevenly implemented by the various local authorities, often resulting in inconsistency and the creation of spaces for negotiation between the local state and religious groups. This, however, is a partial, statist perspective concerning the effectiveness of policy implementation. It is equally important for us to understand how individual believers and Christian groups, with varying degrees of agency, creativity, and autonomy, have either accommodated, resisted, or co-opted the party-state through innovations in theology, organization structure, technology, ritual practices, and transnational social networks.

Conflicts of Interest: The authors declare no conflict of interest.

\section{References}

Cao, Nanlai. 2011. Constructing China's Jerusalem. Stanford: Stanford University Press.

Financial Times. 2018. March 5. Available online: https://www.ft.com/content/8940f2d0-2059-11e8-a8951ba1f72c2c11 (accessed on 4 October 2019).

Gao, Shining. 2005. Dangdai Beijing de Jidujiao yu Jidujiaotu: Zongjiao Shehuixue ge'an Yanjiu. Hong Kong: Daofeng Shushe.

Huang, Jianbo. 2012. Xiangchun Sheqü de Xinyang, Zhengzhi yu Shenguo. Hong Kong: Chung Chi College.

Lian, Xi. 2010. Redeemed by Fire. New Haven: Yale University Press.

Liang, Jialin. 1999. Gaige Kaifang Yilai de Zhongguo Nongcun Jiaohui. Hong Kong: Alliance Bible Seminary.

Lim, Francis. 2009. Negotiating "foreignness", localizing faith: Tibetan Catholicism in the Yunnan-Tibet borderlands. In Christianity and the State in Asia. Edited by Julius Bautista and Francis Lim. London and New York: Routledge, pp. 79-96.

Lim, Francis, and Bee Bee Sng. Forthcoming. Forging Chinese Christian Digital Fellowship: Social Media and Transnational Connectivity. In Religion, Hypermobility and Digital Media in Global Asia. Faith, Flows and Fellowship. Edited by Catherine Gomes, Orlando Woods and Lily Kong. Amsterdam: Amsterdam University Press.

Lozada, Eriberto P., Jr. 2001. God Aboveground. Stanford: Stanford University Press.

Sun, Yanfei. 2017. The Rise of Protestantism in Post-Mao China: State and Religion in Historical Perspective. American Journal of Sociology 122: 1664-725. [CrossRef]

Travagnin, Stefania, ed. 2017. Religion and Media in China. New York and London: Routledge.

Yang, Fenggang. 2005. Lost in the Market, Saved at McDonald's: Conversion to Christianity in Urban China. Journal for the Scientific Study of Religion 44: 423-41. [CrossRef]

(C) 2020 by the author. Licensee MDPI, Basel, Switzerland. This article is an open access article distributed under the terms and conditions of the Creative Commons Attribution (CC BY) license (http://creativecommons.org/licenses/by/4.0/). 

Article

\title{
The Catholic Church in Contemporary China: How Does the New Regulation on Religious Affairs Influence the Catholic Church?
}

\author{
Magdaléna Masláková * and Anežka Satorová \\ China Studies Seminar, Faculty of Arts, Masaryk University, 60200 Brno, Czech Republic \\ * Correspondence: magdalena.maslakova@gmail.com
}

Received: 13 June 2019; Accepted: 19 July 2019; Published: 23 July 2019

\begin{abstract}
The Chinese government has regulated all religious activity in the public domain for many years. The state has generally considered religious groups as representing a potential challenge to the authority of the Chinese Communist Party (CCP), which sees one of its basic roles as making sure religion neither interferes with the state's exercise of power nor harms its citizens. A revised Regulation on Religious Affairs (Zongjiao shiwu tiaoli 宗教事务条例) took effect in 2018, updating the regulation of 2005. This paper aims to introduce and examine the content of the regulation, especially how it differs from its predecessor and how the changes are likely to affect religious groups in China. The Catholic church in China has historical links to the worldwide Catholic church, so articles in the new regulation which seek to curb foreign influence on Chinese religious groups may have more of an effect on Chinese Catholics than on other groups. The paper addresses two main questions: How dose the new regulation affect the Catholic church and what strategies are employed by the Catholic church in order to comply with the regulation? The research is based on textual analysis of the relevant legal documents and on field research conducted in the People Republic of China (PRC). The fieldwork consisted of open interviews with several church members and official representatives of the church conducted in Zhejiang Province between March and May 2018, and in May and June 2019. The paper thus aims to analyze contemporary Chinese religious legislation with respect to the lived experience of Catholics in China.
\end{abstract}

Keywords: China; Catholic church; Regulation on Religious Affairs; Chinese legislation; sinicization; patriotism

\section{Introduction}

In 2005, after 56 years of the People's Republic of China (PRC), the State Council published the Regulation on Religious Affairs 2018 (Zongjiao shiwu tiaoli 宗教事务条例), thus providing the first detailed legal document to manage and regulate religion. Since then, the regulation has already undergone one revision, which was released on 7 September 2017, and came into force in February 2018. The regulation offers a key insight into how the lawmakers see religion and what aspects of religious life they consider important (DuBois 2017). Regulation on Religious Affairs consists of nine chapters ${ }^{1}$ and 77 articles which cover areas such as the registration of religious groups, religious schools and venues, religious activities, online preaching, and fundraising for religious groups. In the hierarchy of legal documents, Regulation on Religious Affairs ranks as the highest comprehensive legal document concerning religious belief in the PRC. ${ }^{2}$

1 The chapters are: General Provisions, Religious Groups, Religious Schools, Venues for Religious Activities, Religious Professionals, Religious Activity, Religious Assets, Legal Responsibility, Supplementary Provisions.

2 The legislative framework can be divided into two main components according to who is enacting them: some legal documents are enacted by the National People's Congress, some by the State Council. This differentiation is important as 
The changes introduced in the revised version of the Regulation affect all religious groups in China, but for some the implications could be more serious than for others. Especially, the question of a foreign influence might be crucial for some religious groups; for example, Christian groups have faced accused of foreign influence more often than other religious groups in China. With this in mind, the focus of this article is the Catholic church in China (Tianzhujiao, 天主教).

As the regulation came into force only recently, it is essential to take a closer look at its content, particularly any changes from its predecessor. It is certainly valid to question the extent to which one can examine the possible impact of the revised regulation given that it has been published so recently, but we believe there are at least some areas where analysis is already possible, such as the restrictions on funding, the use of online platforms, and the control of foreign influence. Several changes have also taken place within the Catholic church itself. In September 2018, Pope Francis signed a provisional agreement with the PRC and made an appeal to the underground church and the official church for unification. The agreement had a significant impact on the church: many underground bishops stepped down from their posts in favor of candidates officially appointed by the Chinese Catholic Patriotic Association (CCPA, Zhongguo tianzhujiao aiguohui 中国天主教爱国会). ${ }^{3}$

The fieldwork for our research was conducted in Zhejiang Province in 2018 and 2019. Data were collected during two fieldwork studies: the first from March to June 2018, and the second in May and June 2019. Both pieces of fieldwork combined interviews with participant observation. Several representatives of the open Catholic church in China were interviewed. For the field research, small cities near Hangzhou were chosen. The selected cities have comparatively small groups of Catholic believers. For example, there were three churches in one of the cities, but, all three churches had just one priest, who commuted between them in order to be closer to certain group of believers. There were slightly different attendants in different churches. This situation is similar to other selected cities, which also face the problem of an insufficient number of clergies. For this reason, all clergy within the cities were interviewed. They do not represent the leadership of the CСPA. They are rather leaders of the local Catholic communities. During the first fieldtrip, 15 people were interviewed, 5 priests and 10 nuns; during the second fieldtrip, 10 people were interviewed, 4 priests and 6 nuns. Some were the very same as interviewed during the previous fieldwork. In the interviews, priests and nuns, as local representatives of religious specialists and church officials, described the current situation of the church, the relationship between the Catholic church and the PRC, and relationships with the foreign Catholic community. We focus on religious specialists as they are leaders in local communities and have a certain authority on religious matters. Lay Catholics are often less interested in state-church relations and may be more concerned with everyday issues. The clergy are more directly influenced by the regulation and any top-down changes as they are the people who organize the church and its activities; the laity can be considered more as passive agents than active agents. ${ }^{4}$ Zhejiang Province has a significant number of Catholic churches. Some scholars have called Wenzhou the 'Chinese Jerusalem' (N. Cao 2010) as the city has large number of Christians, particularly protestants; but a different small city in Zhejiang was chosen for this case study.

\section{Discussions on the Regulation of Religion: An Overview}

The Chinese government is currently promoting the idea of fazhi 法治—the rule of law一and not solely in the realm of religion. One of the simplest definitions of 'rule of law' has been provided by Randall Peerenboom (2002, p. 2):

legal documents overseen by the latter cannot contradict documents overseen by the former. For more detail on which statutes fall into which category, see (Zhuo 2009).

3 Since 1957, there have been two distinct Catholic groups within the PRC: the (official) CCPA under the control of the Communist Party, and the underground church (dixia 地下) loyal to the Vatican.

4 Anyway, there are several cases when laity are engaged in church-state affairs. The assumption of their passivity is mostly focusing on the issues connected to their involvement with managing the church. 
At its most basic, rule of law refers to a system in which law is able to impose meaningful restraints on the state and individual members of the ruling elite, as captured in the rhetorically powerful if overly simplistic notions of government of laws, the supremacy of the laws, and equality of all before the law.

From this concise definition, we can distinguish one of the main elements of the rule of law: no one is above the law, in any sense, whatever their standing in the political spectrum, their wealth, influence or other possible variables. In theory, it should apply equally to the state and to the party. The Chinese government claims fazhi 法治 to be one of the pillars of contemporary Chinese society. ${ }^{5}$ Article 5 of the Constitution of the PRC (a translation is available on the government's website) states that the PRC is a socialist country under the rule of law. Having the term enshrined in the Constitution does not necessarily mean the whole state is under the dominion of the rule of law: many would argue that the way 法治implemented in China means it can be interpreted as the rule by law (Sheehy 2006). Rule by law refers to the situation where the state holds the 'reins' and uses the law as a tool for achieving its own goals (Peerenboom 2002). One characteristic of the rule by law is the creation of general and abstract rules which help to carry out the state's agenda and make no provision for the exercise of restraint on state power (Castellucci 2007).

Whether the PRC operates a system of rule by law or of law continues to be a subject of debate among scholars and sinologists. Peerenboom pursues the 'middle ground' and suggests the PRC is moving towards the rule of law (Peerenboom 2002). Palmer (2009) insists that if the rule of law is to be complied with, the policy on religion requires greater transparency and clearer administrative procedures. All the legislative changes were part of a broader socioeconomic and political program of reform whereby, from 2004 onwards, regulations became more directive of religious organizations, while some of the more ambiguous statements were removed from the statute books (Tong 2010).

Although many scholars continue to insist that rule by law remains prevalent in the PRC and are more critical to the new regulations (G.G. Chen 2017; Homer 2010), others are more optimistic as they believe that the rule of law will eventually bring more openness, freedom and harmony (Kuo 2011; Tong 2010). Lambert (2001), a former British diplomat to China, highlighted that the current ideology of the CCP, based on the thinking of Marx, Lenin, and Mao Zedong, is key to the CCP's position on religion and that atheistic materialism based on socialism should therefore be seen as the basic standpoint of the CCP in any of its dealings with religious groups in China. Potter (2003), on the other hand, believes that it was China's historical experience that created the desire to exert control over religion. Various religions and religious groups have challenged the regime throughout its history, and for this reason, regulating religion in China is more an issue of legitimacy and authority than of ideology.

As there was no legal document that managed religious life in China before 2005, Kuo Cheng-tian suggests that since that year we have seen an important change: a new political process of "[... ] keeping a delicate balance between political correctness and liberal religious policies serve to explain the slow but significant improvement in religious freedom in China over the past decade" (Kuo 2011, p. 1061). The author examines the dynamic between religious bodies and government representatives and suggests that the Chinese government is trying to adapt to the needs of domestic and international groups, including religious groups. Kuo sets out an optimistic but rather unrealistic vision of openness, freedom of religion and harmony in Chinese society. Potter (2003) supported the idea that China should be pushed to follow certain international standards on human rights, including the various 'freedoms', as it is now a part of a globalized world and a leading world economy.

5 Since the 18th CCP National Congress, the term 'rule of law' (fazhi 法治) has been associated with other terms said to represent the core values of socialism in China: prosperity (fuqiang 富强), democracy (minzhu 民主), civility (wenming 文明), harmony (hexie 和谐), freedom (ziyou 自由), equality (pingdeng 平等), justice (gongzheng 公正), patriotism (aiguo 爱国), dedication (jingye 敬业), integrity (chengxin 诚信) and friendship (youshan 友善). The terms are used in official state propaganda and are promoted in schools and displayed in numerous public places. 
The sinologist Wenzel-Teuber (2016) has published a detailed list of the changes in the new regulation on religion. As her article was published in 2016, it reflects the first draft of the regulation, which was published online so that specialists and members of the public could provide feedback. The article is brief and mostly descriptive. Batke $(2017)^{6}$ also provides a necessary comparison between the previous and current drafts of the regulations. Her analysis is primarily based on a comparison between the frequency of selected vocabulary used in the two versions. ${ }^{7}$ Yang (2017) provided further insight into the possible outcomes of the new regulations and described three different strategies towards the Chinese government employed by Christians in China: co-operation, accommodation, and resistance. Yang expressed his concern that the new legislation would bring greater suppression of Christianity in China as many religious activities (such as home Bible studies, religious conferences and publishing religious content on the internet) now needed to be controlled and approved by the State Administration of Religious Affairs (SARA, guojia zongiao shiwu ju 国家宗教事务局), which is now incorporated into the Department of United Front Work (N. Cao 2018, p. 2). ${ }^{8}$ This could be especially problematic for underground Christian groups, who were now officially outlawed by the regulation. Yang also suggested that certain of the revised regulations could be considered a violation of the freedom of religion, a conclusion which is clearly contradicts the government's proclamations concerning the rule of law.

Chinese scholars to have expressed their views on the regulation include Cao Shunli 曹顺利 in his article 《宗教事务条例》解读 Zongjiao shiwu tiaoci jiedu (S. Cao 2005), which explored the processes involved in establishing the new law and suggested that the government created the new regulation to protect Chinese society and all citizens of the PRC. The main aims, according to Cao, are to safeguard national unity and to establish a transparent legal system that can be made known to all religious citizens and so uphold the rule of law. He insisted that the new law was not created hurriedly but over a long period, as befitted such a significant new law. Hu Shaojie 胡绍皆 (Hu 2006) was particularly interested in the impact of the new regulation on religious groups. Hu highlighted the need for religious bodies to educate their members about the regulation-without knowledge of the requirements of the regulation, religious people cannot protect themselves - and sees the new regulation as further promoting harmony in Chinese society. Feng Baojun 冯宝军 (Feng 2016) suggested that the regulation, and its revision, were necessary for preservation of social order and to create a harmonious society. Feng compared the PRC and its regulation on religion with various other countries and their laws and regulations and believes China is following the global trend in publishing more transparent regulations and in doing so is following the rule of law. Many official representatives of the CCPA describe the influence of the regulation on Chinese Catholics in the same way. Their writings, published with the approval of the patriotic association, create a conciliatory image of the Catholic church in China and highlight the similarities between Catholic dogma and socialism. ${ }^{9}$ Some of these proclamations are remarkably similar to official state propaganda as 'state-recognized religious leaders [are] expected to speak within the framework of broader Party policy' (Goossaert and Palmer 2011, p. 321). Froissart (2018) has explained in a recent article: "the Chinese social sciences are more applied in the sense that they are primarily intended to help the state solve social problems" $(2018$, p. 4). For this reason, researchers at Chinese institutions may be under closer scrutiny than Western scholars as it is more important that their research is useful to the government and provides the most accurate data available about a particular issue; equally, they are unlikely to issue any severe criticism of the Party. In the case

6 Formerly a research analyst for the State Department's Bureau of Intelligence, Jessica Batke is an expert on political and social affairs in China. She is currently senior editor of ChinaFile.

7 For example, Batke noticed that ,national security (guojia anquan 国家安全) is cited three times in the new regulations versus one time in the old [version], which led her to conclude that national security is an urgent issue in modern-day PRC.

8 The incorporation of SARA into the United Front Work is an important change as the office is now directly under the leadership of the CCP.

9 According to an article written by the priest Li Zhiyi on how core socialist values are mirrored in basic Catholic teaching. 
of Catholics in China, they often narrate a story of harmonious cooperation and coexistence of the Christian churches and the Chinese government (completely ignoring underground church).

The studies mentioned above indicate different approaches and mixed findings. We believe that the situation is very complicated. Rather than focusing on state-church relations from the perspective of social resistance or state domination, this article considers lived experience and the difference between the official legal norms and what is actually happening on the ground in the open Catholic church in China. In this it follows the stance of Cao Nanlai concerning the need to "understand the meaning of everyday life [... ] to examine the symbolic presence of state power and state relations in the local church community" (N. Cao 2010, p. 2), with a focus on a particular Christian denomination.

The officially open Catholic church is often seen as less involved in the church-state struggle as its theological orthodoxy promotes harmonious cooperation with the communist regime in China. In recent years especially, the Vatican has urged Chinese Catholics to be 'good citizens' and to support the ruling regime ${ }^{10}$. This attitude is often overlooked as many researchers focus on the Protestant churches which oppose the regime and support democracy and civil society (Lim 2019, pp. 2-3). Very few articles have analyzed the situation of the official churches as these are often perceived as 'unproblematic'. We believe, however, that it is also important to consider their case. The CCPA represents a significant number of Chinese Christians in China. And after the signing of the new provisional agreement between the Vatican and the PRC, the CCPA may one day represent all Catholics in China, especially as the signatory, Pope Francis, is in favor of uniting the underground and open churches. He has even appealed to unofficial underground bishops to step down from their posts in favor of candidates officially assigned by the CCPA (Ucanews 2018c).

\section{Sinicizing Christianity}

\subsection{From Yangiiao 洋教 to Sinicized Catholicism}

One aspect of religion that has exercised the CCP from 1949 to the present day is the potentially harmful influence of foreign entities with respect to state security (Slobodník 2007, p. 66). Articles 5 and 57 of the Regulation on Religious Affairs address this very topic: the former is part of the general provisions; the latter is a specific provision.

Article 5:

All religions shall adhere to the principle of independence and self-governance; religious groups, religious schools, and religious activity sites and religious affairs are not to be controlled by foreign forces.

Article 57:

Religious groups, religious schools, and religious activity sites must not accept donations from foreign organizations or individuals that have conditions attached, and where the amount donated exceeds 100,000 RMB; it shall be reported to the religious affairs department of the people's governments at the county level or above for review and approval.

The two Articles share a connection to the policy of self-governance in the PRC, which has been adopted in response to the potential threat to the regime posed by foreign powers. Since the early 1950s, the state has been determined to remove links between foreign (particularly Western) religious entities and religious communities in China. This has clearly been a more significant policy for Chinese Catholics and Protestants. ${ }^{11}$ Article 5 explicitly forbids any foreign control over religious life in the

10 This does not necessarily mean to support the CCPA, but to support the regime and its civil laws and regulations. See Message of His Holiness Pope Francis to the Catholics of China 2010; Apostolic Journey to Pakistan, Philippines I, Guam, Japan, Anchorage 1981.

11 Richard Madsen suggests that the CCP regarded Catholics as especially problematic because of their hierarchical connection to the Vatican (Madsen 2017, p. 28). From 1951, foreign missionaries began to be expelled from the PRC. Around 5000 
PRC. While Article 5 is vague about how those foreign entities could control Chinese religious affairs, Article 57 addresses one way in which that could be seen to happen, that is, through financial support. Monetary donations could be seen as a means whereby foreign organizations 'buy' influence in the country. ${ }^{12}$ To prevent such a strategy, any amount over 100,000 RMB (around 14,500 USD) must be reported to the respective Religious Affairs Department where it will be reviewed and approved. The idea that a donation must be approved raises the question of the circumstances under which the Religious Affairs Department may decline the donation and what criteria are considered when reviewing the donations. In any case, the new restriction may not affect smaller Catholic churches. As explained by one Catholic priest, most funds are from individual smaller donations from local believers or from the renting out of church property. More funds may be forthcoming if the community is building a new church or repairing an existing building, but for the daily needs of the parish, small donations are sufficient (Interview, June 2018). This still nonetheless represents an important change in the regulations.

Catholic Christians are often considered to be less loyal to the CCP than are other believers as they have strong connections outside the country (McCarthy 2013, p. 54), and the Catholic church often has to face allegations of supporting foreign interests instead of the PRC. ${ }^{13}$ Because of a fear of infiltration, the official party historiography has consistently promoted this view through directly linking missionaries and Christian churches to imperial forces (Vala 2012, p. 46; Li et al. 2018, p. 4; Leung 2005, p. 897). Several priests raised their concerns about this issue during interviews. They feel that one of the major problems for Catholics in China is how Catholicism is still by some perceived as a foreign religion, yangjiao 洋教 ${ }^{14}$. One priest stated that, 'The traditional thinking of the majority is still that the Catholic church is a foreign religion, and for this reason they dislike it,' (Interview, May 2018). Another church representative had the same response: 'Some people think that Catholicism is a foreign religion from abroad, so they reject it,' (Interview, May 2019). The priests further explained that the church is actively trying to rid itself of such labels by promoting the localization (bendihua 本地化) and sinicization (zhongguohua 中国化) of the Catholic church, such as by using Chinese music during sermons but mostly by 'following the official direction of the CCP and cooperating with the government', (Interview, April 2018). One priest even directly linked the whole idea of sinicization 中国化 to its political aspect. When asked about the sinicization, he answered: 'In China, it is how it is. We can do nothing about it. The church must follow the Party's leadership', (Interview, June 2019). Since 2015, the Chinese authorities have advocated the 'sinicization of religions' (zongjiao zhongguohua 宗教中国化), ${ }^{15}$ which according to the government should eventually lead to the creation of a harmonious society in China (Zhuo 2014, p. 19)—which might even mean a society

Catholic priests and nuns were forced to leave China; many other members of the Catholic clergy were imprisoned. For more information, see (Charbonnier 2010, pp. 214-46).

12 The PRC is not the only country which is currently dealing with the problem of religious funding. It has been reported in the press that Germany is taking steps against unchecked financial transactions between the entities sending funds and those receiving them. In Germany's case, the money is coming from Qatar, Kuwait and other Gulf states. Germany wants to set new obligations on donors, including the need to register any funds they wish to send to German mosques. Germany's home secretary Horst Seehofer stated that by adopting these policies, Germany intends to arrest foreign influence with regard to Germany's mosques. See (Goebel 2018).

13 In interviews, several atheist university students mentioned that in their view, certain religions promote separatism and endanger national unity. One such student stated: "[While] Buddhism in China teaches you to love your country, [ ... ] some religions, for example Christianity, maybe not. [ ... ] Especially in Tibet. Some religions in Tibet teach people to betray our country, [ ... ] to support America, not our country." The student connected Tibetan Buddhism and Christianity with separatist ideas. According to another recent piece of research on student opinions concerning religion, Li Miao, Lu Yun and Yang Fenggang discovered that among the major religions Catholic Christianity and Islam are held in lowest regard (Li et al. 2018, p. 8).

14 There are, however, many believers and non-believers who do not perceive Catholicism this way anymore. But for the interviewed clergy, the problem of 'foreignness' of the Catholicity was mentioned several times as an issue they have to face.

15 The term refers to a process whereby religious dogma, liturgy, rules and behavior are interpreted and explained in such a way as to fit Chinese society and conform to goals which further the development of the PRC. The official translation is that Chinese religions have to be 'Chinese in orientation', but authors such as Benoît Vermander insist on the term 'sinicization' (Vermander 2019). 
absolutely obedient to the government. During the annual religious conference in 2016, Chinese President Xi Jinping 习近平 stressed the need for different religions to be compatible with socialism and therefore to undergo sinicization. This direction has been stressed ever more urgently since the $19^{\text {th }}$ Congress of the CCP in October 2017. Accordingly, Article 4 of the new Regulation on Religious Affairs mentions the need to support socialism and to practice the core socialist values (shehui zhuyi hexin jiazhiguan 社会主义核心价值观):

Article $4:^{16}$

The State, in accordance with the law, protects normal religious activities, ${ }^{17}$ actively guides religion to fit in with socialist society, and safeguards the lawful rights and interests of religious groups, religious schools, religious activity sites and religious citizens.

Religious groups, religious schools, religious activity sites, and religious citizens shall abide by the Constitution, laws, regulations and rules; practice the core socialist values; and preserve the unification of the country, ethnic unity, religious harmony, and social stability.

These excerpts are suggestive of an ongoing process of the merging of religion and state ideology. It promotes the 'state-leads, religion-follows' model (zhengzhu jiaocong 政主教從) (N. Cao 2018, p. 3). In words of Ping Xiong: 'The government tries to administer almost every aspect of religious activities in order to maintain control over religious bodies, persons, and activities,' (Ping 2014, p. 610). To follow socialism and its values is to promote sinicization (Vermander 2019, p. 4), a connection that is made by President Xi himself:

We must develop the socialist theory of religion with Chinese characteristics, [ ... ] we must continue to walk the path of socialism with Chinese characteristic; actively practice the core values of socialism, promote Chinese culture, strive to fuse together the religious teachings and Chinese culture. (Xi 2016)

President $\mathrm{Xi}$ gave his speech around a year before the Regulation was published. Comparing the first and latest versions of the Regulation, it is obvious that the speech greatly influenced the wording of Article 4, which incorporated phrases such as 'practice core socialist values'. By adding such expressions to the legal document, sinicization became enshrined in the legislation and thus made mandatory, as Cao Nanlai concludes: 'request of churches to promote the idea of sinicization undoubtedly serves the state nationalistic agenda [ ... ] state authorities have strengthened their efforts to resist the cultural impact and presumed infiltrating forces from the West' (N. Cao 2017, p. 28).

The trend towards effecting a harmony between the Catholic faith and Chinese tradition is very clear from articles published in the journal Catholic Church in China (Zhongguo tianzhujiao 中国天主教). The journal is a Chinese periodical published by the CCPA, and the authors of articles and reports are mostly priests and bishops of the open Catholic church. In 2019, many articles referred to sinicization. Obviously, the content of these articles mirrors the official program of the CCPA, which in turn mirrors official state propaganda. In addition to the articles promoting the need to make Catholicism 'more in line with the CCP agenda, another manifestation of the sinicization is the mandatory patriotic seminars in religious schools. ${ }^{18}$ Pursuant to this program, Chinese Catholics

16 Bold type in original.

17 The PRC pledges to protect 'normal religious activities' (zhengchang de zongjiao huodong 正常的宗教活动). The problematic aspect of this term is the lack of any clear explanation. Some suggests 'normal' should be seen as 'legal' and as far as the government officially recognizes a religious group, it is considered authorised and labelled as 'normal' (Zhu 2010, pp. 491-92), but the right to decide what defines 'normal religious activities' belongs to the state, not to the religious communities (Penny 2012, p. 20). Consequently, this terminological ambiguity is beneficial for the regime. In general, the abstract nature of the rules which are later applied by the state leadership in pursuit of their own agenda is inherently linked to the rule by law (Castellucci 2007, p. 63). If that is the case, the state has at its disposal a tool which effectively helps them to regulate all religious activity within its borders.

18 The Catholic and Protestant associations added the term 'patriotic' (aiguo 爱国) to their official name to further express their devotion and loyalty to the regime. 
sought to reinterpret their teaching as one that serves socialism through promoting morality and a united and harmonious Chinese society. Since 2002, the authors of textbooks for this kind of education, both Catholic and Protestant, have interpreted numerous verses from the Bible in light of socialist and patriotic ideals (Kuo 2011, pp. 1042-51). ${ }^{19}$ The new regulations also place a strong emphasis on the education of religious specialists. The 2005 version mentioned facilities for religious education (zongjiao yuanxiao 宗教院校) only 4 times; the new version mentions them 55 times. The issue of state-led religious training has been important for a long time, as patriotic education should incorporate religious clergy loyal to the CCP (Goossaert and Palmer 2011, p. 331). Only professionals with official religious seminary training approved by the government can conduct religious activity (Article 36). Without the official certificate, a religious preacher can be sanctioned in accordance with the law (Yang 2005, p. 429).

The new regulation has a whole new chapter, Chapter III, whose sole focus is the management of religious schools and the verification of the qualifications of those who teach there (Article 16). Religious schools can be established only by the national religious associations or by religious groups at provincial level but under the direction of the central government. No other organizations or individuals are allowed to run institutions for religious schooling (Article 11). Since 2018, religious schools have been officially allowed to employ foreign personnel. This is a totally new regulation not mentioned in any previous document on religion. The previous version only allowed students at religious educational institutions to go abroad for religious training, or foreigners to study at religious schools in China. Of course, many foreigners had previously been invited to lecture at Chinese religious institutions and many priests met foreign missionaries during their theological studies (Interview, May 2018). ${ }^{20}$ But it is important to get the theological training from the official theological seminary administered by the CCPA, as this organization is responsible for the curriculum, and for educating future priests to follow the official state indoctrination. The interviewed clergy did not mention this as a problem as they do not work closely with foreign priests or missionaries. They are based in small cities without collaboration with any foreign personnel.

\subsection{Catholics as Good Patriotic Citizens}

Since the signing of the provisional agreement, Pope Francis has appealed to Chinese Catholics (underground as well as open) to be 'good citizens, loving their homeland and serving their country with diligence and honesty, to the best of their ability' (Message of His Holiness Pope Francis to the Catholics of China and to the Universal Church 2018). The Vatican approves of the CCPA's efforts to free itself from any historical links to imperialism. Some commentators have nonetheless suggested that the state's appeal for greater patriotism may be a tacit appeal to support the Chinese Communist Party (aidang 爱党) (Leung and Wang 2016). Therefore, the Vatican's position might be controversial as by promoting the idea of a 'good citizen' it might unwillingly promote subordination to the CCP.

Although the CCPA is a state institution and therefore follows Beijing's directives, many church members support it in order to avoid being perceived as anti-Chinese or pro-foreign. The church is seeking to create an image of a patriotic Catholic community which is contributing to a harmonious Chinese society (McCarthy 2013, p. 49). In order to promote this supposed harmony between socialism

19 For examples, please refer to the next page on how the Ten Commandments are compared to the core socialistic values by priest Li.

20 To enrol in a seminary, an applicant must provide a letter signed by both parents approving of his desire to become a Catholic priest. Without this approval, the seminary would not take him (Interview, April 2018). When asked about this rule, one nun later explained: 'You need to have approval, but it does not mean that if [the applicant's] parents are not Catholics he would not get that approval. There are some who would agree, but some would not. Some mothers, if they are non-believers, cannot accept their sons becoming priests. There was one priest whose mother even committed suicide because of his decision. So, for this reason, you need the approval,' (Interview, May 2018). Accepting any foreign religious system can violate the norms of family life, and have a negative impact on relations with family members (N.-J. Chen 2003, p. 342). Becoming a Catholic priest, who needs to accept celibacy, might be seen as unfilial. 
and Catholicism, some believers attribute socialist values to Pope Francis, highlighting his support for underprivileged people. One interviewee even suggested that the Pope is an example of a 'good communist' (Interview, May 2019). Patriotism (aiguo 爱国), one of the virtues associated with socialism and sinicization, is described as a Christian value. The priest Li Zhiyi expressed his belief that the Ten Commandments are basically socialist values ( $\mathrm{Li} \mathrm{2019,} \mathrm{p.} \mathrm{20):}$

In the everyday experience of a Catholic, the Ten Commandments and the core socialist values are the same. All Christians have the same values: to love the motherland, to love the people, to promote unity, to be unified with the masses, to promote a harmonious society, even to be unified with people with different worldviews and to be united to and protect people who oppose us. [our belief]

Benoît Vermander concludes: 'Leaders of both the Catholic Patriotic Association and the (Protestant) Three-Self Church were (and are still) striving to find biblical grounds for presenting the guidance of the Party as a form of obedience to God's commandments' (Vermander 2019, p. 8). In the same manner, in interviews one priest often explained that following the official laws and regulations is not only a necessary part of being a good citizen but is closely connected to their faith and their understanding of Catholic dogma. Another interviewed priest explained that it is the duty of Catholics to follow the rules, because 'as believers, we need to obey our religious laws, but in this society, we surely need to obey the laws of the society. If not, we might even hurt someone. We would need to face God's judgement for this, [because] as Catholics we should be good towards others' (Interview, April 2018) ${ }^{21}$. Another priest agreed:

In fact, if you are a good Catholic, following the national rules is easy. The laws are just forbidding you to do such things as physically hurt or assault others or steal from them. But our Christian belief demands that we not only act rightly on the outside [to hurt, assault, steal], but at the same time are good on the inside, in our heart. If you are just being a good Catholic, it is enough. (Interview, June 2019)

Likewise, Chinese Protestants under the official Three Self Patriotic Association highlight the moral values of Christianity. Their position is almost identical to the official narrative of the Catholic church, as Tsai suggests (Tsai 2017, p. 327):

The unregistered Protestant house churches repeatedly express that they are good citizens. In their apologetic writings, they never forget to mention that they love the country, care about the people, espouse national and ethnic unity, and are very willing to contribute their efforts to the advancement of society. Indeed, the Christian virtues they promote are compatible with the socialist morality which CCP would like to see practiced in Chinese society.

In the same way, in interviews, Catholic priests often described patriotism-or a need to love one's country - as loving each and every citizen according to the basic Christian commandment 'love one another' (Interview, May 2018).

While acknowledging official regulations, some priests would still rather follow Christian doctrine than the CCP's demands. As one priest put it:

We are all patriotic, all people in China are patriotic [爱国的]. But the situation in the church is specific. We need to respect the particularity of the church. After first obeying the church, we can be truly patriotic and obey the state. (Interview, May 2018)

Another one explained: '[Socialism and Catholicism] have a different position on the question of beliefs. [ ... ] But, anyway, we need to follow the Party's directive,' (Interview, June 2019). The need to

21 In the interview the priest refered mostly to regulations agains violence and crime. 
follow the rules, but at the same time to be devoted to Christian doctrine, is not unique to the Catholic church. In the Protestant Three Self Patriotic Movement, a similar narrative prevails. Vala (2017) analyzed the Protestant reaction to nationalism and patriotism in the PRC, and the stories Protestant priests told him mirror those shared by Catholic priests. One unregistered Protestant preacher said:

A good citizen will not go beyond the bounds of the laws and regulations [ ... ] [But] if you followed all these regulations, then the Christian gospel would not have spread so widely, because the regulations on public order restrict evangelism. Christians have the life of God, and so we do not have to obey. Because we live for God, so we can violate them. (quoted in Vala 2017, p. 67)

This contradicts the assumption that Catholics who are 'good citizens' and love their country must first cooperate with the CCP and only in second place obey Christian dogma (Leung and Wang 2016).

\section{Chinese Catholics and the Vatican}

The revision of the Regulations redefines the exact functions and duties (zhineng 职能) of the patriotic associations:

Article 8:

(1) to assist the government in the implementation of law, regulations, rules, and policy; to protect the legal rights of religious citizens;

(2) to guide religious affairs; to formulate rules and regulations and to supervise their implementation;

(3) to engage in religious cultural study; to interpret religious canons and doctrine; to construct religious ideology;

(4) to carry our religious education and training; to educate religious personnel, and to appoint and manage them $[\ldots]$.

This is the first time a legal document has regulated the roles and functions of religious groups. The Regulations also now state that it is the task of the Chinese Patriotic Association to interpret religious doctrine and ideology. Religious groups united under the associations are compelled to follow the directives issued by the CCP and to 'recognize the supremacy of the Chinese government on religious matters' (Chan 2012, p. 990). Previously, non-registered religious groups who oppose governmental control were only de facto illegal (Cox 2007, p. 384); now, they are officially outlawed. The new regulations in effect stipulate that the Patriotic Association is now an instrument of the government, and that all religious professionals and educational institutions must follow its directives.

For the Catholic church, the regulation repeats the need for the official church to follow bishops appointed by the CCPA and the authority of Vatican (Article 36). Before the publication of the Regulations on Religious Affairs, the CCPA had not officially recognized the authority of the pope to appoint bishops in China. In recent decades, the association has followed an unofficial agreement on the issue: bishops were generally elected from among those priests who had received approval both from the Chinese government and from the Vatican. Only in exceptional cases was a candidate without papal approval selected (Moody 2012, p. 406). In September 2018, the Vatican and the PRC signed a new provisional agreement on the appointment of bishops, which signaled efforts towards reunification of the Catholic church in China. ${ }^{22}$ Under the agreement, the Vatican grants authority to the CCPA to elect

22 The Catholic church in China has been divided since 1957, when Chinese Catholics loyal to the CCP established the CCPA and started to elect its own bishops without approval from the pope; the organization declared total independence from the Vatican (Madsen 1999). At the same time, the Vatican has long refused to recognize bishops elected by any other authority. Since 1957, there have been two Catholic bodies within the PRC: the CCPA under the control of the government, and the underground church loyal to the pope. Discussions about cooperation between the Vatican and the PRC began during the papacy of John Paul II, and successive popes have increasingly given their approval to bishops elected by the CCPA (Chu 2014, p. 147; Leung and Wang 2016, p. 467). 
Chinese bishops but the Vatican retains the right of veto. ${ }^{23}$ The agreement is a result of many years of negotiations between successive popes and Chinese leaders and even before its signing, the Vatican still carried influence with the official Catholic church. Even if it was only the CCPA who was to interpret Catholic doctrines, many Chinese Catholics have regularly followed news about the pope, who has continued to be considered a moral example and a spiritual leader (lingxiu 领袖). Many believers have followed and shared his teaching about the Christian life on the Internet (Interview, May 2018). As explained by one priest: "The pope is a successor to the apostles of Jesus Christ, a follower of Saint Peter, and therefore we as Catholics should obey him fully' (Interview, April 2018). Although the official CCPA journal Catholic Church in China has rarely mentioned the pope, stories and items of news from the Vatican are often published in the church newsletter published by Hangzhou diocese. The newsletter seems to focus more on the Vatican than on political issues connected with religion in China. On various official Wechat and Weibo accounts, Chinese Catholics are sharing quotations and prayers from Pope Francis or live-streaming sermons from the Vatican. Such local newsletters and articles shared online represent the 'everyday face' of Catholicism in China. The content targets lay believers, who tend to be less interested in the church's political issues. It is normal for members of the open Catholic church to hold a positive image of the pope and to see themselves as connected to the one united Catholic church. Chinese Catholics publish not only passages from the Bible, prayers and local news from the diocese, but also news about the pope. This was the case before the provisional agreement was signed, and even more so since.

\section{Restriction and Cooperation}

Church members come together through online groups on social networking sites and microblogs, which they use to organize meetings, masses and trips; they often share pictures and prayers (Interview, May 2019). Some even use social networking for proselytizing (Lim 2019, p.11). The regulation nonetheless prohibits the publishing of religious content on the Internet without approval from the government, (Article 47, 48; see Yang 2017, p. 79) which performs thorough surveillance of the kind of religious information that is being spread. A new draft of the Measures on Administration of Internet Religious Information Service proposes strict control over the sharing of content via the Internet. The draft is yet to be enforced and is still open for comments, but if it is accepted, groups and individuals will need to apply for a license to share religious content, and foreigners will not be allowed to engage in it (Article 7). Such a license, which will be valid for three years only (Article 14), will enable the holder to 'interpret religious doctrine and rules with content conducive to social harmony, the progress of the times, and healthy civilization' (Article 16). The new measures could represent a sizeable obstacle for the church. One church visited has its own private Wechat group, the sole purpose of which is to share religious content; its members are active every day. Restrictions on this activity could well discourage believers and further constrain their already limited religious freedom.

Similarly, although religious organizations are officially allowed to publish and distribute printed materials with religious content, the regulation prohibits the printing of religious materials which promote disturbance or separatist ideas (Article 45): on the contrary, religion is to be an instrument of the government for promoting socialism and a harmonious society (Li 2019; Zhang 2016; Fang 2005). Notably, the regulation does not forbid the publishing of the current version of the Bible, although within the patriotic associations, there are attempts to change its content so as to render it compatible with the CCP's agenda (Vermander 2019, p. 5).

23 Four days after the agreement was signed, Pope Francis conciliated seven bishops elected by the CCP who had not previously obtained papal approval, requested underground bishops to abdicate from their positions in favor of bishops elected by the CCPA, and has consistently advocated on behalf of the unification of the underground and open churches in China. See (Message of His Holiness Pope Francis to the Catholics of China and to the Universal Church 2018). After the signing of the agreement and the Pope's message, several opposing voices have been raised. Many criticise the Pope for seeking an alliance with a totalitarian regime such as the PRC (Ucanews 2018b). 
Numerous restrictions on the circulation of the Bible have been reported (Ucanews 2018a). Under the regulation, Bibles cannot be sold on or downloaded from the Internet and foreign religious materials cannot be distributed without government approval; only 'a reasonable amount for personal use' is permitted (Article 46). ${ }^{24}$ The trend towards stricter control are already noticeable: some unofficial printed religious materials were available at the churches visited during the fieldwork; a year later, there are no such materials. ${ }^{25}$

The churches had been unaffected by the program of demolitions even though they are in Zhejiang province, which has been one of the main targets, ${ }^{26}$ churches in other provinces have also been facing destruction. During interviews, Catholic priests did not mention the issue, but a Protestant pastor from the same area raised his concerns at an unofficial meeting: 'In this city, we are blessed. But friends from Henan are having problems: [the government] is destroying their churches, they want to eliminate them' (Interview, June 2019).

The new regulation allows religious groups to file an administrative lawsuit if they are dissatisfied with an administrative action issued by a Department of Religious Affairs:

Article 75:

Where anyone is dissatisfied with administrative acts taken by the religious affairs departments, they may lawfully apply for an administrative reconsideration; where dissatisfied with the decision of the administrative reconsideration, they may lawfully raise an administrative lawsuit.

Article 75 thus offers an opportunity for churches to challenge the administrative decisions of local governments: ${ }^{27}$ first by applying for administrative reconsideration, ${ }^{28}$ and if still dissatisfied with the outcome, by filing an administrative lawsuit. This does not mean a religious group necessarily has a real chance of an unbiased process: the decision-making body in each case could be influenced by the CCP. Also, the courts in China are answerable to the National People's Congress-they are not independent of the state or free its legislative or executive power. The CCP can decide to intervene if they deem that a topic being discussed in court is politically sensitive, and religious questions can of course fall into that category. Such interventions can also occur when the court finds itself ruling on a law that is vague or arguable (Horsley 2007, p. 102). Interpreting a law somewhat loosely-for example, by not defending a normal religious activity which the state proclaims to protect-can help the state to keep control of any future interpretation, making it easier for it to use the law as means of exercising power. The situation has improved in recent years with the establishment of the China Judgements Online site in 2014, which now makes rulings of the Chinese courts accessible to the public (Finder 2017, p. 247). This makes it, at least theoretically, more difficult for the state to intervene in the courts. Nonetheless, it seems that few in the Catholic church in China would ever dare to think

24 Nonetheless, in June 2019 it is possible to order a Bible on Taobao, a Chinese online shopping platform, in both English and Chinese.

25 For example, during a pilgrimage to Sheshan basilica in Shanghai in 2018 many leaflets were given to the visitors. This year, no materials were prepared, and the pilgrimage was restricted to a smaller area.

26 The campaign began in 2013 and was officially finished in 2016. One of the churches visited had been built just before the announcement of the '3+1 campaign' (san gai yi chai 三改一拆)—suggesting that one in four buildings would be demolished (Yang 2017, p. 87). Open churches were not so much affected by the campaign as the official targets were buildings belonging to unauthorised churches (N. Cao 2017, p. 30).

27 Occasions when an administrative decision is required (Religious Affairs Regulations. 7 July 2004, as amended on 26 August 2017) include:

Article 12: When establishing religious schools.

Article 21: When establishing religious sites.

Article 30: When building large outdoor religious statues.

28 For the legislative framework on this topic, see: Law of the People's Republic of China on Administrative Reconsideration. 29 April 1999. Available at: http://www.npc.gov.cn/englishnpc/Law/2007-12/11/content_1383562.htm. 
of challenging a decision of the government. On the contrary, many priests and nuns repeatedly declared their aim to create and maintain good relationships (guanxi 关系) with the local government. One priest expressed his greatest wish as follows:

It is definitely to be able to develop and spread the Gospel. But in China today, the situation is that many, especially in this region, say our belief is a superstition. In many places, there are just a very few believers or friends of the church, just about one or two families. [ ... ] Another thing that I also wish is that relations with the government would develop, as our law declares that it should respect our beliefs. (Interview, April 2018)

Developing good relations with the government may also be a question of survival. When asked her opinion regarding patriotism, one nun mentioned that with respect to relationships with the government, 'patriotism does not influence us. But the Party can decide to shut down a church. But in this area, our relations with the government are good, therefore we can manage our church freely, and they would not close us down' (Interview, May 2019). Filing an administrative lawsuit was not considered a possibility for a church if the government decided to demolish or otherwise remove it. The only chance is for a church to foster 'unofficial' relationships with people in local government if it wishes to continue its work without interference. Some of the more prominent members of Catholic churches may benefit from ties to local officials, who might turn a blind eye to certain activities (Chambon 2019, p. 31): cooperation between religious bodies and local governments is hardly uncommon in the context of authoritarian regimes (Koesel 2014, p. 160). For clergy in the open church, it is easier to follow (most of) the CCP's regulations and maintain good relations with the local government, and this can lead to a more benevolent approach from the government towards the parishes concerned (Goossaert and Palmer 2011, p. 321). Such collaboration is often mutually beneficial- the church is free from strict government supervision, and the government need not fear any opposition or resistance from the church. This mutuality is noticeable from observing the everyday life of smaller Catholic churches in Zhejiang province. On the one hand, there are often many children present, ${ }^{29}$ even though they should not officially participate in religious activity as according to the Constitution only Chinese citizens over 18 years of age are allowed to freely exercise religious belief. ${ }^{30}$ But at the same time, in sermons church leaders would rarely address sensitive topics or mention politics and instead focus solely on the daily issues and moral problems of the believers. They would rather self-censor their preaching than upset the status quo. Yang (2006) proposed a system of 'red', 'black', and 'grey' markets with respect to religion: in this scheme, the open Catholic church represents the red market as it has status as a legal religious organization; but in its everyday life, it is closer to the grey market, as church members are often involved in illegal activities. Such behaviors are tolerated by the government as long as they do not implicitly oppose the governmental policies.

We should not forget that the process of enforcing regulations in the field of religion in China differs from province to province: some local government leaders and cadres may allow certain unofficial activities; in other places, the control is more sustained (Lambert 2001). What is permitted or overlooked in northern Zhejiang province may be extremely problematic in other parts of China. This is not to say, however, that every open church is blindly following all the rules set out by the CCP. Many Catholic priests and nuns are nonetheless concerned about the everyday needs of believers and

29 This has, however, become less common since the end of 2018. In the churches visited in March-May 2018, it was an exception for children to attend mass, but in May 2019, at the same churches, parents with small children were taking part in weekly meetings. Children were aged between one and ten years; older children had the content of the mass explained to them. These were not likely to have been newcomers to the church; the arrival of any new parents with children is possibly the outcome of the gradual connecting of the underground and official Catholic churches as these families might originally have been members of an underground church. This is only an assumption-we have not conducted interviews with these new church members.

30 The law prohibits proselytising among children, but it is common for religious parents to introduce their faith to their children (Yang 2006, p. 97). 
fear drawing too much attention to the local church. They are only too aware that, 'if you oppose the government, you will have trouble' (Interview, April 2018).

\section{Conclusions}

This study tried to answer two main questions: How is the new regulation affecting the Catholic church and what are the strategies employed by the Catholic church in order to comply with the regulation. Considering that this study is limited by the selected group of interviewees who are part of the official CCPA organization, it is possible that they felt inclined to support the party line during interviews, but based on our results we argue that in many ways, the updating of the Regulation on Religious Affairs and the legislation on religion in China simply highlight the CCP's long-lasting fear of separatism, of the influence of foreign entities, and of possible challenges to the Party. The Party and officials within the leadership of the CCPA have continually sought to create a narrative that projects the creation of a legal system that protects religious beliefs. It seems more plausible, however, that the regulation is a tool that will allow the state to shape the religious life of Chinese citizens. For many years, the state has been determining the legal discourse on religion and creating strict boundaries between legal and illegal forms of religious activity. The newly enforced procedures are following this powerplay and demonstrating the uneven nature of church-state relations. The party-state still holds a dominant position of authority over religiosity within its borders and continues to tighten its control through institutionalization and sinicization. The continuation of state authority continues to weaken the position of religion in China. In certain spheres, such as international influence or the recognition of specific religious groups, the state's dominant position gives it a clear advantage over religious groups, such as regarding its ability to define what 'normal religious activities' are and use this term at its own discretion.

The leaders of the Chinese Catholic Patriotic Association are becoming little more than collaborators who help to propagate the Party's propaganda and attempt to connect core socialist values with the Christian dogma. They implement this high-level indoctrination through the mandatory patriotic training program in theological seminaries that is designed to produce priests who will finish their training as loyal subjects of the CCP; if they are not overtly loyal to the Party, they must at least acknowledge its leadership.

On the other hand, local Catholic clergy represent a form of Catholic religious activities that are more closely associated with the 'everyday' experience of lay believers. They are often not concerned with the same issues as the leaders of the CCPA, and the activities of many local churches do not fit clearly within legal parameters. The priests of the open Catholic church are well aware of the situation and are mostly 'playing according to the rules' as it is essential for them to protect their activities and their small communities. As Michel Chambon concludes (Chambon 2017, p. 195), the situation for the Catholic church has changed little, as we can observe 'a political status quo that allows Christians to exist openly as long as they implicitly respect the leadership of the Party.' Nonetheless, many articles within the regulation can become a tool in the hands of the government, and be used by the state to crack down on religious groups in the 'grey' area of the Chinese religious market, and this can have serious consequences for many local parishes.

Author Contributions: Formal analysis M.M. and A.S., writing - original draft M.M., writing - review \& editing A.S. All authors read and approved the final manuscript.

Funding: This research received no external funding.

Conflicts of Interest: The authors declare no conflict of interest.

\section{References}

Batke, Jessica. 2017. PRC Religious Policy: Serving the Gods of the CCP. China Leadership Monitor 52: 1-9.

Cao, Nanlai. 2010. Constructing China's Jerusalem: Christians, Power, and Place in Contemporary Wenzhou. Redwood City: Stanford University Press. 
Cao, Nanlai. 2017. Spatial Modernity, Party Building, and Local Governance: Putting the Christian Cross-Removal Campaign in Context. China Review 17: 29-52.

Cao, Nanlai. 2018. Chinese Religions on the Edge: Shifting Religion-State Dynamics. The China Review 18: 1-10.

Cao, Shunli. 2005. The Regulation on Religion Explained 《宗教事务条例》解读. Journal of Hunan Institute of Socialism 23: 32-33.

Castellucci, Ignazio. 2007. Rule of Law with Chinese Characteristics. Annual Survey of International \& Comparative Law 13: 35-92.

Chambon, Michel. 2017. Are Christians Pentecostal? A Catholic Reading of Pentecostal Influence on Chinese Christians. In Global Chinese Pentecostal and Charismatic Christianity. Edited by Fenggang Yang, Joy K. C. Tong and Allan H. Anderson. Leiden and Boston: Brill.

Chambon, Michel. 2019. Urban Catholicism in China. Le Civiltá Cattolica 3: 26-38. [CrossRef]

Chan, Shun-Hing. 2012. Changing Church and State Relations in Contemporary China: The Case of Mindong Diocese, Fujian Province. The China Quarterly 212: 982-99. [CrossRef]

Charbonnier, Jean. 2010. Chinese Catholics in the Early Nineteenth Century. In Handbook of Christianity in China: Volume Two: 1800 to the Present. Edited by R. G. Tiedemann. Leiden and Boston: Brill, pp. 214-46.

Chen, G. George. 2017. Le Droit, C'est Mo: Xi Jinping's New Rule-By-Law Approach. Available online: http://ohrh.law.ox.ac.uk/le-droit-cest-moi-xi-jinpings-new-rule-by-law-approach/ (accessed on 4 April 2019).

Chen, Nan-Jou. 2003. Contextualizing Catholicity: A Taiwanese Theology of Identification. Asia Journal of Theology 17: 341-363.

Chu, C. Y.-Y. 2014. China and the Vatican, 1979-Present. In Catholicism in China, 1900-Present: The Development of the Chinese Church. Basingstoke: Palgrave Macmillan, pp. 147-68.

Cox, Lawrence. 2007. Freedom of Religion in China: Religious, Economic and Social Disenfranchisement for China's Internal Migrant Workers. The Asian-Pacific Law and Policy Journal 8: 371-430.

DuBois, Thomas David. 2017. China's Religion Law and the Perils of Counting Consciousness. In Disturbances in Heaven. Edited by Ivan Franceschini, Kevin Lin and Nicholas Loubere. Canberra: ANU Press, pp. 92-97.

Fang, Litian. 2005. The Construction of Harmonious Society and the Role of Religion 和谐社会的构建与宗教的作用. Chinese Religion 中国宗教 7: 18-19.

Feng, Yujun. 2016. The Implementation of the Regulation on Religion: Discussion on Legal Documents on Chinese Religion 行动中的《宗教事务条例》: 中国宗教事务管理查及其法律评价. The Journal of the Northwest University of Nationalities 西北民族大学学报. Available online: http://www.cssn.cn/zjx/zjx_zjyj/zjx_ddzj/ 201607/t20160725_3133231.shtml (accessed on 22 July 2019).

Finder, Susan. 2017. China's Evolving Case Law System in Practice. Tsinghua China Law Review 9: 247-59.

Froissart, Chloé. 2018. Issues in Social Science Debate in Xi Jinping's China. China Perspectives 4: 3-9.

Goebel, Nicole. 2018. Germany to curb Mosque Funding from Gulf States. Available online: https://p.dw.com/p/ 3AiK (accessed on 17 April 2019).

Goossaert, Vincent, and David A. Palmer. 2011. The Religious Question in Modern China. Chicago and London: The University of Chicago Press.

Homer, Lauren. 2010. Registration of Chinese Protestant House Churches Under China's 2005 Regulation on Religious Affairs: Resolving the Implementation Impasse. Journal of Church and State 52: 50-73. [CrossRef]

Horsley, P. Jamie. 2007. The Rule of Law in China: Incremental Progress. In The China Balance Sheet in 2007 and Beyond. Available online: https://law.yale.edu/system/files/china-law-documents/2007_china_balance_sheet_ publ_rol_paper_090212_05rule_of_law.pdf (accessed on 17 April 2019).

$\mathrm{Hu}$, Shaojie. 2006. Survey about the Regulation of Religion after One and Half Year of Its Effect 《宗教事务条例》 实施一年半综述. Focus 关注 9: 38-44.

Koesel, K. J. 2014. Religion and Authoritarianism: Cooperation, Conflict, and the Consequences. New York: Cambridge University Press.

Kuo, Cheng-tian. 2011. Chinese Religious Reform. Asian Survey 51: 1042-64.

Lambert, Tony. 2001. The Present Religious Policy of the Chinese Communist Party. Religion, State E Society 29: 121-29.

Leung, Beatrice. 2005. China's Religious Freedom Policy: The Art of Managing Religious Activity. The China Quarterly 184: 894-913. [CrossRef]

Leung, Beatrice, and M. Wang. 2016. Sino-Vatican Negotiations: Problems in Sovereign Right and National Security. Journal of Contemporary China 25: 467-82. [CrossRef] 
Li, Zhi Yi. 2019. The Catholic Dogma and the Core Socialist Values 天主教信仰与社会主义核心价值观的践行. Catholic Church in China 中国天主教 1: 18-19.

Li, Miao, Yun Lu, and Fanggang Yang. 2018. Shaping the Religiosity of Chinese University Students: Science Education and Political Indoctrination. Religions 9: 309. [CrossRef]

Lim, Francis K. G. 2019. "Serving the Lord": Christianity, Work, and Social Engagement in China. Religions 10: 196. [CrossRef]

Madsen, Richard. 1999. China's Catholics. Tragedy and Hope in an Emerging Civil Society. Berkley: University of California Press.

Madsen, Richard. 2017. Signs and Wonders: Christianity in Contemporary China. In Christianity in Contemporary China. Socio-Cultural Perspectives, 2nd ed. Edited by Francis K. G. Lim. New York: Routledge, pp. 17-30.

McCarthy, Susan. 2013. Serving Society, Repurposing the State: Religious Charity and Resistance in China. The China Journal 70: 48-72. [CrossRef]

Message of His Holiness Pope Francis to the Catholics of China and to the Universal Church. 2018. Available online: http://w2.vatican.va/content/francesco/en/messages/pont-messages/2018/documents/papa-francesco_ 20180926_messaggio-cattolici-cinesi.html (accessed on 5 April 2019).

Moody, P. 2012. The Catholic Church in China Today: The Limitations of Autonomy and Enculturation. Journal of Church and State 55: 403-31. [CrossRef]

Palmer, David A. 2009. China's Religious Danwei: Institutionalising Religion in the People's Republic. China Perspectives 4: 17-30.

Peerenboom, Randall. 2002. China's Long March toward Rule of Law. Cambridge: Cambridge University Press.

Penny, Benjamin. 2012. The Religion of Falun Gong. London: The University of Chicago Press.

Ping, Xiong. 2014. Freedom of Religion in China under the Current Legal Framework and Foreign Religious Bodies. BYU Law Review 2013: 605-18.

Potter, Pitman B. 2003. Belief in Control: Regulation of Religion in China. The China Quarterly 174: 317-37. [CrossRef]

Regulation on Religious Affairs 宗教事务条例. 2018. The Policy of the Central Government of the PRC 中华人民共和国中央人民政府. Available online: http://www.gov.cn/zhengce/content/2017-09/07/content_ 5223282.htm (accessed on 8 June 2019).

Sheehy, Benedict. 2006. Fundamentally Conflicting Views of the Rule of Law in China and the West \& (and) Implications for Commercial Dispute. Northwest Journal of International Law and Business 26: 225-66.

Slobodník, Martin. 2007. Mao and Buddha: Religious Policy Towards Tibetan Buddhism in China (Mao a Buddha: Náboženská politika voči tibetskému buddhizmu v Číně). Bratislava: Chronos.

Tong, James W. 2010. The New Religious Policy in China: Catching up with Systemic Reforms. Asian Survey 50: 859-87. [CrossRef]

Tsai, Yan-zen. 2017. "We Are Good Citizens": Tension between Protestants and the State in Contemporary China. In Religion and Nationalism in Chinese Societies. Edited by Cheng-tian Kuo. Amsterdam: Amsterdam University Press, pp. 309-36.

Ucanews. 2018a. Bible Rewrite Helps Stoke Censorship Fears in China. Available online: https://www.ucanews. com/news/bible-rewrite-helps-stoke-censorship-fears-in-china/81983 (accessed on 5 May 2019).

Ucanews. 2018b. Chinese Catholics Remain Split over Vatican Deal. Available online: https://www.ucanews.com/ news/chinese-catholics-remain-split-over-vatican-deal/85007 (accessed on 14 May 2019).

Ucanews. 2018c. Vatican Mission Oversees Chinese Underground Bishops Stepping Aside. Available online: https://www. ucanews.com/news/vatican-mission-oversees-chinese-underground-bishops-stepping-aside/84147 (accessed on 7 May 2019).

Vala, Carsten T. 2012. Protestant Christianity and Civil Society in Authoritarian China: The Impact of Official Churches and Unregistered "Urban Churches" on Civil Society Development in the 2000s. China Perspectives 3: 43-52.

Vala, Carsten T. 2017. Protestant Reaction to the Nationalism Agenda in Contemporary China. In Christianity in Contemporary China. Socio-cultural Perspectives, 2nd ed. Edited by Francis K. G. Lim. New York: Routledge, pp. 59-77.

Vermander, Benoît. 2019. Sinicizing Religions, Sinicizing Religious Studies. Religions 10: 137. [CrossRef]

Wenzel-Teuber, Katharina. 2016. The State Council Publishes a Draft Revision of the Regulations on Religious Affairs'. Religions \& Christianity in Today's China 6: 21-24. 
Xi, Jinping. 2016. Comprehensively Improving the Level of Religious Work According to the New Situation 全面提高新形势下宗教工作水平. April 23. Available online: http://www.xinhuanet.com/politics/2016-04/23/ C_1118716540.htm (accessed on 17 April 2019).

Yang, Fenggang. 2005. Lost in the Market, Saved at McDonald's: Conversion to Christianity in Urban China. Journal for the Scientific Study of Religion 44: 423-41. [CrossRef]

Yang, Fenggang. 2006. The Red, Black, and Gray markets of Religion in China. The Sociological Quarterly 47: 93-122. [CrossRef]

Yang, Fenggang. 2017. From Cooperation to Resistance: Christian Responses to Intensified Suppression in China Today. The Review of Faith \& International Affairs 15: 79-90.

Zhang, Zhigang. 2016. Sinicization of Religions: A Theoretical Contemplation. Study of World Religions 世界宗教研究 3: 21-29.

Zhu, Guobin. 2010. Prosecuting 'Evil Cults:' A Critical Examination of Law Regarding Freedom of Religious Belief in Mainland China. Human Rights Quarterly 32: 47-501. [CrossRef]

Zhuo, Xinping. 2009. Religion and Rule of Law in China Today. BYU Law Review 519: 1-6.

Zhuo, Xinping. 2014. Relationship between Religion and State in the People's Republic of China. Religions $\mathcal{E}$ Christianity in Today's China 4: 1-6.

(C) 2019 by the authors. Licensee MDPI, Basel, Switzerland. This article is an open access article distributed under the terms and conditions of the Creative Commons Attribution (CC BY) license (http://creativecommons.org/licenses/by/4.0/). 

Article

\title{
A Sinicized World Religion?: Chinese Christianity at the Contemporary Moment of Globalization
}

\author{
Nanlai Cao \\ School of Philosophy \& Institute of the Study of Buddhism and Religious Theory, Renmin University of China, \\ 5/F Renwen Building, Beijing 100872, China; nanlai_c@hotmail.com
}

Received: 17 July 2019; Accepted: 30 July 2019; Published: 1 August 2019

\begin{abstract}
This essay explores the rise of Protestant Christianity at the contemporary stage of China's globalization as a unique social and cultural phenomenon. Globalization can be seen as not only a homogenization process in political and economic terms, but also a process in which religious ideas and moral principles spread around the world. While in an earlier phase of globalization lack of Christianity was once constructed as a moral argument to ban Chinese migration to the Christian West, in the current context of China's aggressive business outreach and mass emigration Christianity has become a vital social force and moral resource in binding Chinese merchants and traders in diaspora. By linking the rise of a sinicized version of Christianity in secular Europe with China's present-day business globalization, I hope to suggest a new transnational framework for studying Chinese Christianity, which has often been examined in the nation-based political context of church-state relations, and for rethinking it beyond the static, decontextualized system of world religions.
\end{abstract}

Keywords: Chinese Christianity; Chinese Diaspora; transnational religion; migrant entrepreneurship; globalization; Europe; Christian mission

\section{Introduction: The Nexus of Religion and Globalization}

The last two centuries have witnessed the intertwined development of religion and state secularism in the global context of nation-building. The rise of the modern category of "religion" itself was a global phenomenon accompanied by the formation of modern nation states worldwide (Asad 1993; van der Veer 2013). While at the contemporary moment globalization has often been understood in terms of the global spread of the ideologies and institutions of neoliberalism, consumerism, and migration, this is far from a homogenizing process as many social scientists have found out. On the contrary, there has been a dynamic return to the strong nation-state, the rise of the new state space, and local-place based identity. Globalization has sometimes contributed to the resilience of authoritarian states by channeling strategic resources from around the globe to build up state capacity to prevent democratic change, and it can also lead to the rise of transnational religious extremism and religiously inspired violence by promoting religion's entanglement with political power and ideology as evidenced by the tragic attacks of 11 September 2001. Along with the resurgence of world religions or the great traditional faiths, new religious movements, syncretic religious practices, and new immigrant religions have flourished which often reflect the meshing of local popular culture, folk spiritualties, nationalist sentiment, and institutional religious traditions in the global religious domain. To better understand the fate of religion in an increasingly globalized world, we need to take into account these new geopolitical configurations and power contestations and achieve a more contextualized understanding of lived religious experience. This paper explores the nexus of religion and globalization in a concrete Chinese social context from an empirically grounded bottom-up approach.

Previous studies show that Western religious ideas do not transform local Chinese conditions in a simple, uniformed fashion, but work in ways mediated by local structures and concepts, and local 
Chinese are not passive recipients of global forces, mostly of European and North American origin (Jansen et al. 2014). There exist diverse, multiple actors within the Chinese religious field. These actors and agents usually include the state, religions, academics, Western missionaries, and Chinese religious reformers and merchants. Their ideas and practices have interacted and played an important part in the transformation of the Chinese religious field over the last two centuries of drastic political and social change.

China's modernization can be seen as a globalizing project. Given the historical linkage between Christianity and Western institutions there is much congruence between categorizations rooted in western modernity and the self-understanding of societies and organizations dominated by Christian culture. As China began to be integrated into the modern world system, globally generalized concepts such as religion were being applied, challenged, and modified in the Chinese context, where there was incommensurability between taxonomies associated with Christianity and the reality constructed through traditional Chinese religious and cultural lens. Much of existing research highlights the importance of Christianity as the normative model of religion in the making of the Chinese religious field (see Goossaert and Palmer 2011). Not surprisingly, the interrelationship between religion and globalization has primarily been set in the historical context of the encounter between missionary figures and local Chinese agents, further reinforcing the dichotomous ordering of the western global and the Chinese local (see Cao 2018). While the China/West dichotomy appears visible in discussions of the role of Western Christian forces and concepts in shaping the Chinese religious scene, there is an intellectual urgency of challenging a seemingly common narrative of globalization that assumes it originated in the West and spreads to other parts of the world, thus transforming the lives of non-western local people. When people talk about religion and globalization, the concept of religion usually refers to Abrahamic religions and encompasses such abstract and seemingly universal notions as truthfulness, justice, and compassion (e.g., Volf 2016). This emphasis is deeply rooted in Protestant theology in the western context where western Christianity has become the prototype of global religion. Drawing on ethnographic field research conducted among Chinese Christians in Europe spanning over a decade, I hope to establish a framework for rethinking the contemporary link between Chinese Christianity and China's globalization so as to counter the Western-centric view on Christianity's one-way penetration of Chinese society and culture. ${ }^{1}$

Christianity has figured prominently in the history of China-West encounters. While stories and studies of western missionaries to China are plentiful and common, the neglected other side of the coin is the western opposition of Chinese immigrants based on perceived non-Christian compatibility. For example, in U.S. history there was a long period of time from 1882 to 1965 when Chinese immigration was strictly restricted by the federal Chinese Exclusion Act of 1882 and the national quota system (1943-1965). Although economic competition in the American west appeared to be the major motivation behind Chinese exclusion, lack of Christian values and allegiances on the part of the Chinese was a paramount concern among American policy-makers and factored strongly in the moral argument against Chinese immigration, especially the immigration of Chinese women because of "the widely held view that all Chinese women were prostitutes" (Chan 1991, p. 95). Much of the stereotypical knowledge about the Chinese being immoral "pagans" and "heathens" was evidently derived from early western Christian mission efforts in China, and partly a byproduct of racial distinction and white supremacy. Due to the exclusion-era law prohibiting the immigration of the wives or families of Chinese, there was an extremely skewed sex ratio among the Chinese in the U.S. during the first half of the twentieth century, and white missionary-led churches in the bachelor society of Chinatown served as important "rescue homes" for women facing the serious problems of concubinage and prostitution (Cayton and Lively 1955). Both in China and the Chinese diaspora early Western missionaries conceived

1 See DeBernardi (2001) and Nagata (2005) for pioneering studies on diasporic Chinese Christianity in postcolonial Southeast Asia, which presents an interesting reference point for understanding the role of Chinese agency in localizing and contextualizing the global religion. 
of their work to evangelize "heathens" in the "aggregated paganism", thus distancing themselves from the indigenous elements of the Chinese world.

Soon after the establishment of the People's Republic of China in 1949, foreign missionaries were expelled by the new Communist regime. Christianity has been thoroughly indigenized through close contact with immediate local Chinese realities. The influence upon Chinese Christianity directly brought by western missionaries has faded away but a lot comes from immigrant Chinese Christian churches overseas instead, exhibiting a mode of mutual penetration between the Chinese churches in China and those based in diaspora. Since the turn of the new century Europe has become increasingly the center of global migrations from other parts of the world. Chinese immigrants, such as those from Chinatowns in Paris and Rome, have formed transnational church networks that originate in China, and whose operations largely rely on ethnic trading communities and networks. Therefore, this is a story of multidirectional religious transmission under globalization, rather than an overwhelmingly unidirectional movement from the global center to the passive margin or the cultural penetration and reconstruction of Chinese society by the west that characterizes the early modern phase of globalization (see Casanova 2018). The following analysis puts emphasis on issues concerning Christianity and community formation among the Chinese diaspora in France and Italy, the organization and social impact of Chinese immigrant churches, and the development trajectory of Chinese Christianity in the contemporary post-modern, post-secular global age.

\section{Chinese Christianity in Diaspora: Beyond Cultural Assimilation}

So far, little scholarly attention has been paid to the globalization of Chinese Christianity or the story of Chinese Christianity on a global stage. Research on Chinese Christianity in diaspora has mainly focused on Chinese conversion to Christianity which is the majority religion in the Western context (see, e.g., Cao 2005; Yang 1999). However, we know little about how Chinese migrants brought with them their own homegrown Christian faith to the West and other parts of the world from China and created their religious diaspora and mission stations. ${ }^{2}$ The mass participation of Chinese merchants and traders in migrant churches in Europe contrasts sharply with the mass conversion of Chinese professionals (scholars and students) to Christianity in the United States (see Yang and Tamney 2006). The latter group has been well documented, while increasingly secularized Europe provides a new context for researching Chinese Christianity that cannot be seen simply in terms of a unidirectional mode of assimilation to a Western religious culture, but rather the antidote to assimilation.

Unlike in the United States, where religion in general and Christianity in particular enjoys privileged status in society, in highly secularized Europe, state regulatory framework generally discourages the active presence of immigrant religion in social life, and churchgoing is not considered a virtue by the public. ${ }^{3}$ However, as this study shows, a highly indigenized Chinese Christianity has taken roots in post-Christian Europe almost in total isolation from local European Christians and churches. In recent decades, a large number of Chinese Christians, originated from the coastal Chinese city of Wenzhou, have migrated to Europe especially France and Italy without proper travel documents and with a sole purpose to make money. ${ }^{4}$ Many of them were previously rural migrant entrepreneurs and itinerant traders within China before emigration (Li 1999). According to various estimates by immigrant church insiders, there are hundreds of Chinese churches across Europe. Italy is home to around 70 Chinese churches and nearly 30,000 Chinese believers, constituting the largest presence of Chinese Christianity in Europe. France has the second largest Chinese church community in Europe, with around 40 Chinese churches and 10,000 church members, mostly concentrated in the urban districts of Paris. One important feature that distinguishes these Chinese Christians in Europe

See Cao (2013a) and Cao et al. (2018) for two notable exceptions.

See Berger et al. (2008) for a contrast between the religiosity of the United States and the secularity of Europe.

The issue of migrant illegality is generally downplayed in the church setting. When asked, they often invoke the notion of God's grace to provide moral legitimacy for their theoretically illegal migration and business practices. 
from those in North America is that they are mostly not new converts but had become Christians in China before emigration.

Since the turn of the new century, the large group of Chinese migrant traders and merchants from the Wenzhou region has acquired great visibility and begun to dominate the Chinese churches in Europe ${ }^{5}$ The Chinese communities in Europe are heterogeneous in terms of their geographic origins, their migratory patterns and the multiplicity of the waves of their migration. However, it seems that only these Wenzhou people have been able to build their ethnic, place-specific congregations and evangelistic networks on such a grand scale and with such high visibility across Europe, thanks to the practical logic of Christian entrepreneurs and the dynamic, locally developed business model of Wenzhou church development (Cao 2008). They are known as China's global go-getters, spreading Chinese commerce across the globe. In particular, they operate small businesses such as garment factories and trade light industrial products between China and Europe and across Europe. They have brought an indigenous Chinese Christianity to Europe along with their household based economy. Popularly known as "China's Jerusalem", the coastal Chinese city of Wenzhou is home to thousands of self-started home-grown Protestant churches and a million Protestants (around 20\% of the local population), and has become a regional center of global capitalism since the 1990s (Cao 2011).

Most Chinese churches in Europe are not officially registered as religious organizations but as nonprofit organizations due to various legal restrictions in the host society. ${ }^{6}$ Some do not register at all for the purpose of avoiding official scrutiny or just for convenience. Furthermore, most of them have actively avoided contact with non-Chinese local churches or congregations in Europe. The formation and expansion of this diasporic religious community relies heavily on these Wenzhou traders' newfound wealth from transnational business and the informal household based model of church development. This can be seen as a natural extension of the extensive house church networks operating in legal gray areas in mainland China. Wenzhou churches in Europe are usually controlled and managed by a small number of nondenominational male lay leaders or "boss Christians" who financially contributed the most to purchasing or acquiring the church properties (cf. Cao 2008). The churches also serve as a nexus of social power for them. Not unlike rural house churches in China, the household economy constitutes the backbone of church development in the Chinese diaspora, and accordingly migrant churches always refer to the number of households (hu 户) as the basic unit rather than the number of baptized individuals when calculating membership size. Chinese migrant church leaders encourage the practice of endogamy among church members both as a way to achieve, and as a byproduct of, congregational stability, and the ethnic community, the congregation, and individual households form many concentric circles with God being at the center. This tight-knit community and family atmosphere is especially salient among Wenzhou Chinese immigrants in France. Wenzhou Christians in France enjoy a relatively long history with some geographic advantage in conducting business and religious activities, which tend to develop around Paris-the international trade metropolis.

One Paris-based Wenzhou preacher and garment trader says that if his business fails he can still rely on the 180 households in his church, and the brothers and sisters would not let him starve. Migrant church leaders are not only socioeconomically connected to their congregations within France but also maintain transnational ties with those who lead migrant Wenzhou churches in other European nations and whom they had prior contact back in the Wenzhou church in China before their emigration. This has resulted in transnationally coordinated efforts to fund new Chinese church building projects

5 There are also Wenzhou Christian merchants in North America, but they do not form their own place-based business enclave or congregations, partly due to their small population and their spatial dispersion. Chinese immigrants from Fujian and Guangdong have traditionally dominated Chinatowns and Chinese Christian churches in North America whereas Wenzhou immigrants are latecomers.

6 Specifically, in France Chinese churches tend to be registered as "Association" in accordance with the French association law of 1901, and in Italy as "Organizzazione Non Lucrativa di Utilità Sociale" (ONLUS). 
both in China and in Europe and to launch high-profile joint petitions against the recent Chinese state-led cross-removal campaign that removed hundreds of rooftop crosses in Wenzhou and the surrounding regions in Zhejiang Province. ${ }^{7}$ Church workers and lay leaders often further expand their networks throughout the European Union as their family businesses move from one country to another, seeking new opportunities and taking advantage of the visa-free regime in the Schengen zone. Accordingly, there is a preacher rotation system (paigong 派工) following the Wenzhou model of church development, through which preachers regularly rotate among migrant churches within the host country and sometimes even across different Schengen countries. Both in conducting church work and doing business, they take Europe as a whole.

Wenzhou Chinese churches in France might be a unique case. Against the backdrop of China's current globalization; however, their strategy of adaptation is not uncommon. The growth of Chinese Christianity in Italy proceeds in a similar fashion but in an institutionally distinct way as in France. Comparing to the tight-knit ethnic religious enclave centering in Paris, Chinese migrant churches in Italy spread all over its long, narrow, strip-shaped territory in geographically dispersed settings and are mainly organized into three distinct but interconnected parishes (muqu 牧区), namely the northern parish, the middle parish and the southern parish. ${ }^{8}$ All of the three parishes operate under the national central board of deacons (zonghui zhishihui 总会执事会). In both countries, Chinese merchant families play an essential supportive role behind the expansion of immigrant Chinese Christian church. In particular, Wenzhou Chinese merchants, traditionally with a strong cultural emphasis on familialism, dominate the leadership structure of the immigrant churches. Developing in two different countries in parallel, Chinese migrant Christian communities share the same family model of operation, characterized by congregational independence, an autonomous space, and a conservative patriarchal morality, while adapting to different local contexts.

Among countries in the European Union, Italy's lax immigration control and less developed commercial economy are external factors behind why Italy-based Chinese Christians tend to have higher mobility and develop even stronger internal religious bonding. After the economic crisis in the Euro-zone, Italian industries suffered from heavy damages. Many enterprises and businesses went bankrupt and were closed down. The crisis has led to many Chinese Christian businesspeople migrating out of the surrounding parishes that they used to live. It is also not uncommon for them to relocate during seasonal downtime. The spatial dispersion of more than fifty major Chinese immigrant churches throughout the Italian territory allows these mobile traders and merchants to find their new churches or meeting points nearby relatively easily wherever they travel. ${ }^{9}$ This unique religious spatial arrangement, together with a centralized nationwide preacher rotation and dispatch system, also encourages mobile religious agents such as lay leaders and preachers to move from one place to another without losing their social and religious capital within the larger ethnic religious system. Their credentials and leadership positions are recognized not only throughout the national system of Chinese church coworkers in Italy, but also in neighboring Greece and Malta, where there are newly planted Chinese migrant churches.

Unlike their counterparts in Italy who scatter around the country and are governed by a centralized national pastoral system, most Chinese immigrants in France have chosen to live in Paris due to the availability of vast business opportunities there. Furthermore, many Chinese Christians in Paris I have

7 For details of the church cross-removal campaign (see Cao 2017).

8 This parish system is clearly borrowed from the Wenzhou model of church development in China. Unlike in Wenzhou where each parish is responsible for dispatching preachers to different churches to conduct services, in Italy it is the national central board of deacons that is in charge of the entire preacher-dispatch system among the immigrant Chinese Christian community and coordinates church work between different parishes. In France, Chinese churches tend to concentrate in Paris and there is thus no need to adopt this parish system.

9 In Italy, besides a major unified evangelical Chinese Church system that consists of more than fifty churches and more than two hundred centrally appointed preachers across the nation, there is a much smaller, separately organized Pentecostal and charismatic-oriented Chinese church system called the Chinese revival church (huaren fuxing jiaohui). 
come to know have arrived in France from Italy, seeking business opportunities. For them, Italy is more suitable as a transfer station while France is the true final destination. Due to the dominance of socioeconomically advantaged elite and elderly overseas Chinese immigrants, the immigrant Chinese churches in Paris have developed in a highly competitive context with each protecting its relative organizational independence and guarding against the act of "stealing sheep" by other churches. The oldest Parisian Wenzhou Chinese church that claims more than a thousand registered members has recently split into several smaller churches because of unresolved internal conflicts among elderly lay leaders. Nevertheless, Chinese immigrant churches in Europe are, after all, not elite Chinese organizations overseas like the chamber of commerce, but constitute a large, openly participatory domain and a popular grassroots movement of new immigrants. The nationwide system of Chinese Christian parishes which spread all over Italy acts as a good example. It has not only met the need of mass social participation by nonelite immigrants who are often on the move for new business opportunities and who are relatively socioeconomically homogenous, but made it possible to mobilize material and pastoral resources readily across regions for the launch of new church programs and the staging of major evangelistic events.

Under this centralized pastoral system, more than two hundred lay preachers have been chosen to affiliate with the national board of coworkers (zonghui tonggong 总会同工), and each Sunday they are dispatched to different Chinese churches across Italy to deliver sermons. This number is still growing as more Chinese churches are being planted in Italy and need immediate pastoral resources and service. One young preacher belonging to this national system of co-workers told me that all of the preachers within this system work as part-time volunteers and do not receive remuneration or reimbursement of travel expenses in any form because they consider their work as an act of self-sacrifice and spiritually meaningful. This means they have to use personal funds to cover their substantial travel expenses. As a result, only well-to-do merchants or traders can afford to take this mobile job.

The development of Chinese immigrant churches in Europe has been subjected to normative "isomorphic pressures" (DiMaggio and Powell 1983). When immigrant Chinese merchants, consciously or unconsciously, bring and integrate a relatively successful business model and pragmatic business logic into their church organizations, the operation of the latter would resemble that of an immigrant business enterprise. Wenzhou merchants' family businesses and their immigrant churches are isomorphic in operational logic and organizational structure. In particular, immigrant church leadership tends to lie in the hands of close relatives as in the case of immigrant family firms. This institutional isomorphism is further reflected in their practices of investment, endogamy, and the construction of family relationship, all of which is conducted in a similar fashion with achieving family solidarity and fulfilling communal commitment as the ultimate goal and fundamental value. The immigrant family and the family-style church provide the perfect emotionally supportive context for the transmission of the religion cross generationally. Chinese youth spend much time socializing with one another in various church settings such as youth fellowship meetings, bible study groups, youth group outings, summer and winter camps, Christmas performance, and evangelization-related activities, and consequently they tend to meet their potential mates in a highly controlled Chinese context. Sometimes the training of the younger generation of preachers and church leaders also starts from the immigrant family-style church. Young would-be preachers are usually arranged to first practice preaching in front of an audience that includes their parents and grandparents or in front of their home churches attended by relatives before being formally considered and appointed by the national board of deacons of the immigrant Chinese church.

This institutional isomorphism can also find expression in the use of church space. One direct example is the story of a Wenzhou church lay leader and garment businessman in Paris who uses the site of the local church as his business office. When he was asked about why his office address on his business card is the same as that of the church, he frankly responded "when activities are held in the church, this is the office for the church, otherwise it is the office for my business." The line between the church and the secular business world is rather casual and ambiguous, which to some 
extent reflects the pragmatic business logic of immigrant lay leaders. The church's nonregistered status also allows lay leaders to merge business with religion without legal hurdles. This partly explains why many of the Chinese immigrant churches are not formally registered as religious sites. Without an overarching central interpretive authority structure in managing religious practices and symbols, immigrant churches are prone to becoming a multifunctional community center that caters to the socioeconomic needs of the immigrants who, instead of taking cultural assimilation for granted, value social, material, and spiritual connections with the Chinese homeland. This highly mobile household-based Chinese Christianity, with its emphasis on transnational religious connections and institutional and spatial autonomy in diaspora, provides an important counterpoint against the popular views on Christian conversion and cultural assimilation that characterize the research paradigm of US-based immigrant religions (see Warner 1993).

\section{The Discourse of a Globalizing Chinese Christianity and the Salience of State Categories in Global Evangelization}

In recent years, backed by China's intensified commercial engagement with Europe, there has been a shift of direction in today's Chinese mission movement, from a Western mission-founded into-China movement focusing on work among Chinese minorities to an ethnic Chinese-led global mission movement. This has much to do with the worldly engagements of diasporic Chinese Christians in Europe who are spearheading this movement and who seek to integrate their evangelical work with the Chinese state-led "one belt, one road" initiative for global development. These Chinese Christian lay leaders have intentionally developed connections with hegemonic state discourse on cultural nationalism as embodied in the Chinese dream of national rejuvenation. In so doing, they flexibly position themselves as a contributing force in the current Chinese project of nation building and global reordering (rather than forces of global western cultural imperialism). It is noteworthy that unlike what Western missionaries in China did a century ago, today's Chinese Christians in Europe are not evangelizing Europeans, but forming exclusive congregations, although there is a popular discourse in the church highlighting the role of the diaspora Chinese in an envisioned "reverse mission" to Europe. There are tight national and ethnic boundaries undergirding this Chinese "mission" which mainly targets fellow Chinese immigrants at the current stage.

Europe needs spiritual revival (lingming fuxing 灵命复兴), and Chinese churches can work together to bring God's blessings to Europe. This is a recurring theme repeatedly popped up in the sermons and church-run seminary training courses in migrant Chinese churches. The regular and frequent face-to-face gathering of mobile migrant Chinese church leaders from different parts of Europe, facilitated by the visa-free scheme of the Schengen region, further strengthens such a Chinese-centered vision among the first generation of immigrants. While they acknowledge a debt to Europeans for bring Christianity China a century ago, they now assume the responsibility of global evangelization. In contrast to France where French republicanism stresses cultural assimilation and where laïcité has been a dominant ideological principle of secularism in society, Italy is far more tolerant to the public presence of immigrant religions, and a lot of immigrant Chinese Christian evangelistic projects and outreach activities have taken place in Italy. For example, sponsored by the "one belt, one road" gospel network, the first Sino-Europe evangelism symposium (hua' ou xuanjiao yantao dahui 华欧宣教研讨大会) was held in Rome in September 2017 with the theme "Challenges and Mission of the Chinese Church in Europe in the 21st Century". Topics discussed include the Islamization of Europe, refugee crisis, homosexual marriage, youth problems, and the Chinese evangelical mission in Europe. In October 2018, a pan-Europe pastoral ministry and leadership symposium (quanou jiaomu ji jiaohui lingxiu yantaohui 全欧教牧暨教会领袖研讨会) with the theme “calling and mission" (huzhao yu shiming 呼 召与使命) was held in Rome and attended by nearly 200 people. Church leaders from 12 European nations were invited to share information about the Chinese churches in their respective nations and consolidate the Chinese evangelistic vision. 
Facilitated by the discourse on globalizing Chinese Christianity, some high profile evangelical events have taken place in Italy. Under the larger context of religious and cultural pluralism in Italy, Chinese immigrant churches have successfully staged several public special gatherings (tehui 特会) that brought together young Chinese from different parts of Europe. At such occasions, Christian-filtered Chinese cultural values are celebrated and inscribed in European public space, where issues of cohabitation, homosexuality, and abortion are increasingly tolerated. Evangelical Christianity offers these Chinese migrants a new lens in which to interpret their migrant experience and identity as well as articulate a spiritual defense against cultural assimilation into European secularity and social liberalism.

The most important and memorable activity I participated in during my field trip to Europe was “Love in Rome Century Music Festival” (ai zai luoma 爱在罗马) on June 30, 2018. The Chinese evangelical music event in the heart of the Eternal City was the first major European public event for evangelical Chinese Christians with the aim to celebrate the Apostles Peter and Paul 1950 years after their martyrdom. Officials from the municipal government of Rome were invited to attend to lend legitimacy to this Chinese cultural event and the Vatican newspaper La Stampa featured a long report titled "Chinese evangelical Christians in Rome, in memory of the martyrs" in its world news section afterwards. The choice of the location-the Circus Maximus-where Christians were said to be persecuted by the emperor Nero in ancient Rome, burn alive or eaten by wild beasts, was a deliberate attempt to symbolically mark the change in the spatial structure of global Christianity and highlight the spiritual role of the Chinese. The event featuring several Chinese Christian pop music stars drew several thousand young evangelical and Pentecostal Chinese Christians not only from Rome and from all over Italy, but also from other European countries who arrived on coaches. ${ }^{10}$ The resources and funds for producing this public event mostly came from the Wenzhou church in mainland China. The total cost for this 3-hour concert was 6 million yuan (about 800,000 USD). ${ }^{11}$ Preachers from Wenzhou, China were invited to give sermons and prayers in Rome in Mandarin Chinese and to help convert new Chinese immigrants. The concert opened with a short documentary introducing the history of Chinese migration from Wenzhou to Europe, putting the evangelical Christian event in the reform-era context of China's economic globalization. This shift in the direction of the new mission movement is not only reflected in the spatial movement of pastors and lay preachers but also seen in the movement of religious objects. Bibles, hymn books, and even choir robes used in the Chinese churches in Europe are almost all imported from China.

The main idea that has emerged from my close encounters and interactions with these migrant Chinese Christians and enables me to think Chinese Christianity differently is that the usual nation-state centered framework of church-state relations might not be adequate in capturing the dynamism and vitality of Chinese Christianity at this contemporary global moment. As China's official restrictions on religion increasingly motivate the Chinese house church to channel its resources to a "reverse mission" overseas, a group of transnational Chinese Christians have actively engaged in producing religious activities and events that link China and Europe and in attaching evangelistic meanings and symbolic markings to Europe's urban space. For instance, the Mission Center (xuanjiao zhongxin 宣 教中心) of the Chinese Christian Church in Italy used to be mainly responsible for organizing and supporting short-term mission trips each summer to the interior, western regions of China, often in collaboration with the Wenzhou church in China. It has shifted its priority in operation since the Chinese government stepped up measures against Christian missionary activities and their mission stations in ethnic southwestern China, to which they had regularly conducted evangelization from

10 According to my count, there were approximately 3000 to 4000 attendees at this event. Some evangelistic Chinese church leaders put the event attendance number at 20,000, which is a gross exaggeration apparently out of a desire to put them at the center of a great revival.

11 Although there are strict financial regulations in Europe, money can easily flow between China and Europe in both directions through informal channels. Sometimes, Chinese immigrants can even complete their business transactions in Europe by simply mobilizing and transferring funds between their bank accounts within China. 
Europe, were closed down. Targeting the unreached potential converts in Europe, especially the Chinese immigrant youth and second generation youth at the current stage, these well connected and globally positioned lay leaders and preachers quickly redirected their resources and energies back to Europe.

In the same line of using Europe as a base for Chinese evangelism, a Chinese Christian preacher couple who attend the same migrant church has set up a tourist company that caters to the need of Chinese Christian customers from both Europe and China who come to Rome to visit the footsteps of the apostles in the bible in order to deepen their spirituality. The Christian wife acts as tour guide and Italian-Chinese interpreter. They are proud of their ability to tease out and narrate the spiritual significance of the European city based on solid biblical knowledge in guided tours. Besides operating regular tours for tourists from China, the Christian tour company has been most frequently used by members of Europe-based Chinese churches and visiting Chinese pastors and preachers from other parts of the world. Sometimes they offer discounted service to those who can bring along potential Chinese converts, thus creating an ethnic religious and commercial node within the larger structure of the enclave economy. They also organize frequent group pilgrimage trips to Jerusalem for Chinese guests in Europe and those directly from China. Near China's public holidays such as the golden week for the National Day, their online advertisement would urge Chinese Christians in Europe to invite their relatives back in China to visit Europe's historical Christian sites, by making euro payments in Europe for the tour services.

The strong emphasis on the central role of the Chinese race in the evangelistic vision of bringing Christian blessings to Europe seems unequivocally ethnocentric. It nevertheless speaks to the reality of China's rising soft power on the global stage associated with its economic rise that has culturally empowered Chinese migrant traders and merchants in general. It comes no surprise that Chinese Christian groups choose to emphasize ethnic or subethnic identity as a deliberate evangelistic strategy in a historically and traditionally Christian cultural context (cf. Nyíri 2003). This also seems to be a common pattern among Asian American Christians (Yang and Ebaugh 2001). However, the main difference between Chinese Christians in Europe and their counterparts in America is the former's strong cultural entwinement with Chinese state categories and its being a salient marker of communal identity. This echoes what I have depicted in a previous study on the phenomenon of "spiritual nationalism" in the reform-era Chinese Christian context. I use the term to capture the multilayered process in which advantaged urban Chinese Christians internalize nation state norms, fashion themselves as modern religious subjects compatible with the nation-building project, and adapt and contribute to the rise of nationalism from below (Cao 2012). Some Chinese Christian groups have formulated what they call "God's China vision" (zhongguo yixiang 中国异象), meaning that China will rise not only in the economic sphere but also in the spiritual realm. As one Wenzhou Christian businessman put it, characteristically, "The international community is paying great attention to China. To look at the GDP, China is now the second largest economy. In the spiritual field China may take the last baton in the global evangelical movement."

The competing and even militant global religious vision can be found in the Chinese-led "Back to Jerusalem Movement". The ultimate goal of the China vision is for the Chinese to evangelize the Muslim nations in the Middle East and eventually bring the Gospel back to Jerusalem. Although the "Back to Jerusalem Movement" has incurred criticism from some Western-based China ministries for being a scam, today, in the Chinese immigrant church circle, many believe that the Gospel came from Jerusalem and it must be brought back to Jerusalem eventually. In their narratives, this is like running a relay race in which different countries and peoples in different periods play different roles in this great mission of evangelizing the globe. It is not exaggerating to say that a transnational geography of Chinese Christianity has emerged with the Chinese diaspora in Europe being the center of God's mission. However, the discourse about Chinese as the main vehicle for bringing the gospel to Europe is kept very general and almost always with reference to the expected role of second generation Chinese immigrants in reaching out to potential (non-Chinese) European converts. This attests to the fact that 
there is currently a general lack of inter-ethnic exchanges and trust among the first generation in the Chinese churches in Europe.

In secularized Europe, evangelical Christianity can provide a normative and morally superior context for migrant Chinese to imagine their native place and a shared future of their cultural positioning in an increasingly exclusionary context (Cao 2013a). In France, more than in Italy, Chinese immigrant churches have developed in the direction of high tension with the secular culture of the host society, creating a parallel society and an enclave of identities, faith, and businesses. To fend off unwelcome secular cultural influence from the mainstream society, some indigenous Chinese preachers have used a conservative religious language associated with moral absolutism to train young church members and church workers. In so doing, these immigrant churches are able to effectively pass on their evangelical faith to the younger generation in a spiritual and moral enclave.

This Sinocentric project of global evangelization involves a redemptive process in which advantaged Chinese Christians seek to overcome victimization and suffering inflicted by secular state modernity through repaying China's "gospel debts" (fuyin zhai 福音债) to missionary-sending Western nations a century ago. Backed by their recent experiences and memories of state-led spectacular economic modernization and shaped by the values of their social class, urban elite male Christians often show willingness to embrace state categories and express contempt for the lack of textual theological knowledge and greater social concerns among lay women and elderly members (Cao 2013b). Inspired by nationalistic native Pentecostal leaders in the early twentieth century, their prophetic vision is that China will eventually rule the world not only in economic terms, but also in the spiritual realm, and China will transform from a traditional missionary receiving nation to a glorious missionary sending nation.

\section{Conclusions: Thinking beyond the Static Category of World Religions}

With the rise of a powerful international discourse on nation-building, the type of religiously inspired self-imposed moral isolation among Chinese Christians in diaspora as described above might continue to heighten. While this sinicized version of Christianity offers an alternative to the secular Chinese project of nation building by addressing the "China dream" in spiritual terms, it seems unlikely to contribute to the building of a global civil society with an insular island mentality. This socioreligious phenomenon begs the following questions. Is this a case of malfunction of the world religion or just an example of uncivil local communal religion? Can a "sinicized" world religion possibly avoid entanglement with state power and ideology in the context of China's modernization and globalization?

In the book Flourishing: Why we need religion in a globalized world Protestant theologian Miroslav Volf (2016) provides us with a theologically-framed global religious vision in which great world religions such as Christianity and Islam can play a positive role in achieving peace and reconciliation and in establishing a global order. This normative theological argument provides the public with a unique religious perspective on the ongoing and morally ambivalent project of globalization which has often been habitually understood in political economic terms. It sheds light on how religionists should coexist and deal with nonreligious or a-religious people. However, its definition of world religions (p. 69), which is centered on "transcendence" and its distinction from the local mundane realms of culture, politics and the economy, is typically a theological construct that guides human interaction but not about religion as experienced in real-life setting. Such normative theological definition clearly puts world religions and local religions in a static, overessentialized, dichotomous framework. Volf (2016, p. 86) goes so far as to argue that "local religions with universal pretensions are the most violent of all religions." If we can break from traditional congregational studies of Christian churches and overcome congregational barriers in looking at Chinese Christianity and its relationship with identity formation, community development and everyday life in the Chinese diaspora, we will soon be able to come to the conclusion that the great world religion of Christianity has been adopted and made very local by those practicing it in daily context. Indeed, empirically speaking, all religions 
bear universalist tendency and locally embedded features, although there are important tensions between the universalizing aspects of religion to which migrant populations may appeal, and their specific localized forms which provide a sense of stability and identity in an otherwise rootless world (Tapp 2014).

This study advances the research on immigrant religious organizations, which has been to a large extent modeled on the American experience. It goes without saying that the history of human migration long preceded the emergence of nation states. In the past two centuries of globalization, migration and the rise of an international system of nation states have developed symbiotically, and migration control has gradually become a sovereign right of receiving nations (McKeown 2008). In the earlier phase of globalization, lack of Christianity constituted part of a moral argument to justify the U.S. exclusion of Chinese labor immigrants and strict border control in the 1880s, while the other side of the coin is that for centuries Christian missionaries have traditionally travelled in a north-to-south direction. However, today's diasporic Chinese church networks have spread horizontally across the Schengen region and created diaspora mission stations in the global North. The increasingly coordinated development of a sinicized Christianity in Europe has spiritualized private Chinese business and familial interests, and Europe is even presented as an important battleground of the global evangelization of the gospel by the Chinese. As such, Christianity is far from a passive, responding force at the contemporary stage of China's global business outreach and mass Chinese emigration. This highly mobile, sinicized version of Christianity, imbued with intense worldly aspirations, requires us to transcend the traditional Western-centric view of Chinese Christianity as simply a derivative of Western missionary Christianity and to closely examine the cultural identity and moral imagination of Chinese Christians in agentive pursuit of prosperity and success at this contemporary global moment.

Funding: This work was supported by a grant from the fund for building world-class universities (religious studies) of Renmin University of China (project no. 2018).

Acknowledgments: I thank Roberto Cipriani for giving me the opportunity to stay at the International Center for the Sociology of Religion during the summer and winter of 2018 while I was conducting fieldwork in Rome.

Conflicts of Interest: The author declares no conflict of interest.

\section{References}

Asad, Talal. 1993. Genealogies of Religion. Baltimore: The Johns Hopkins University Press.

Berger, Peter, Grace Davie, and Effie Fokas. 2008. Religious America, Secular Europe?: A Theme and Variations. London and New York: Routledge.

Cao, Nanlai. 2005. The Church as a Surrogate Family for Working Class Immigrant Chinese Youth: An Ethnography of Segmented Assimilation. Sociology of Religion 66: 183-200. [CrossRef]

Cao, Nanlai. 2008. Boss Christians: The Business of Religion in the "Wenzhou Model" of Christian Revival. The China Journal 59: 63-87. [CrossRef]

Cao, Nanlai. 2011. Constructing China's Jerusalem: Christians, Power, and Place in Contemporary Wenzhou. Stanford: Stanford University Press.

Cao, Nanlai. 2012. Elite Christianity and Spiritual Nationalism. Chinese Sociological Review 9: 27-47. [CrossRef]

Cao, Nanlai. 2013a. Renegotiating Locality and Morality in a Chinese Religious Diaspora: Wenzhou Christian Merchants in Paris, France. The Asia Pacific Journal of Anthropology 14: 85-101. [CrossRef]

Cao, Nanlai. 2013b. Gender, Modernity, and Pentecostal Christianity in China. In Global Pentecostalism in the 21st Century. Edited by Robert Hefner. Bloomington: Indiana University Press, pp. 149-75.

Cao, Nanlai. 2017. Spatial Modernity, Party Building, and Local Governance: Putting the Christian Cross-Removal Campaign in Context. China Review 17: 29-52.

Cao, Nanlai. 2018. A Review of Globalization and the Making of Religious Modernity in China. The China Journal 80: 169-72. [CrossRef]

Cao, Nanlai, Giuseppe Giordan, and Enzo Pace, eds. 2018. Chinese Religions in China and Italy. Religioni e Società 91. [CrossRef] 
Casanova, Jose. 2018. Locating Religion and Secularity in East Asia Through Global Processes: Early Modern Jesuit Religious Encounters. Religions 9: 349. [CrossRef]

Cayton, Horace R., and Anne O. Lively. 1955. The Chinese in the United States and the Chinese Christian Church. New York: Bureau of Research and Survey, National Council of the Churches of Christ in the United States.

Chan, Sucheng. 1991. The Exclusion of Chinese Women, 1870-1943. In Entry Denied: Exclusion and (the Chinese Community in America 1882) the Chinese Community in America, 1882-1943. Edited by Sucheng Chan. Philadelphia: Temple University Press, pp. 94-146.

DeBernardi, Jean. 2001. The Localization of Christianity among Chinese in Singapore and Malaysia. In Chinese Populations in Contemporary Southeast Asian Societies: Regional Interdependence and International Influence. Edited by Jocelyn Armstrong, Warwick Armstrong and Kent Mulliner. London: Curzon, pp. 171-208.

DiMaggio, Paul, and Walter W. Powell. 1983. The Iron Cage Revisited: Institutional Isomorphism and Collective Rationality in Organizational Fields. American Sociological Review 48: 147-60. [CrossRef]

Goossaert, Vincent, and David Palmer. 2011. The Religious Question in Modern China. Chicago: University of Chicago Press.

Jansen, Thomas, Thoralf Klein, and Christian Meyer, eds. 2014. Globalization and the Making of Religious Modernity in China: Transnational Religions, Local Agents, and the Study of Religion, 1800-Present. Leiden and Boston: Brill.

Li, Minghuan. 1999. "To Get Rich Quickly in Europe!": Reflections on Migration Motivation in Europe. In Internal and International Migration: Chinese Perspectives. Edited by Frank N. Pieke and Hein Mallee. Richmond: Curzon, pp. 181-98.

McKeown, Adam. 2008. Melancholy Order: Asian Migration and the Globalization of Borders. New York: Columbia University Press.

Nagata, Judith. 2005. Christianity among Transnational Chinese: Religious Versus (Sub)ethnic Affiliation. International Migration 43: 99-130. [CrossRef]

Nyíri, Pál. 2003. Moving Targets: Chinese Christian Proselytising among Transnational Migrants from the People's Republic of China. European Journal of East Asian Studies 2: 263301. [CrossRef]

Tapp, Nicholas. 2014. Epilogue: Religion and Mobility in a Globalising Asia. In Religion and Mobility in a Globalising Asia: New Ethnographic Explorations. Edited by Sin Wen Lau and Nanlai Cao. London and New York: Routledge, pp. 119-28.

van der Veer, Peter. 2013. The Modern Spirit of Asia: The Spiritual and the Secular in China and India. Princeton: Princeton University Press.

Volf, Miroslav. 2016. Flourishing: Why We Need Religion in a Globalized World. New Haven: Yale University Press.

Warner, R. Stephen. 1993. Work in Progress toward a New Paradigm for the Sociological Study of Religion in the United States. American Journal of Sociology 98: 1044-93. [CrossRef]

Yang, Fenggang. 1999. Chinese Christians in America: Conversion, Assimilation, and Adhesive Identities. University Park: Penn State University Press.

Yang, Fenggang, and Helen Rose Ebaugh. 2001. Religion and Ethnicity among New Immigrants: The Impact of Majority/Minority Status in Home and Host Countries. Journal for the Scientific Study of Religion 40: 367-78. [CrossRef]

Yang, Fenggang, and Joseph Tamney. 2006. Exploring Mass Conversion to Christianity among the Chinese: An Introduction. Sociology of Religion: A Quarterly Review 67: 125-29. [CrossRef]

(C) 2019 by the author. Licensee MDPI, Basel, Switzerland. This article is an open access article distributed under the terms and conditions of the Creative Commons Attribution (CC BY) license (http://creativecommons.org/licenses/by/4.0/). 
Article

\title{
The Rise of Calvinist Christianity in Urbanising China
}

\author{
Jie Kang \\ Department of Religious Diversity, Max Planck Institute for the Study of Religious and Ethnic Diversity, \\ 37073 Goettingen, Germany; Kang@mmg.mpg.de
}

Received: 28 May 2019; Accepted: 11 August 2019; Published: 15 August 2019

\begin{abstract}
Over the past decade, Reformed Christianity, broadly based on the theology of Calvinism, has spread widely in China, especially by appealing to Chinese 'intellectuals' who constitute most of the house church leaders in urban areas. It draws its moral guidance from a so-called rational or intellectual focus on biblical theology, reinforced by theological training in special seminaries. It consequently rejects the 'heresy' of the older Pentecostal Christianity, with its emphasis on charisma, miracles, and theology based on emotional 'feeling'. This Reformed theology and its further elaboration have been introduced into China in two main ways. The first is through overseas Chinese, especially via theological seminaries in Singapore, Malaysia, and Indonesia. For instance, preachings of the famous Reformed pastor Stephen Tong (唐崇荣) have been widely disseminated online and among Chinese Christians. Second, Korean missionaries have established theological seminaries mainly in cities in northern China. This has resulted in more and more Chinese church leaders becoming advocates of Calvinism and converting their churches to Reformed status. This paper asks why Calvinism attracts Chinese Christians, what Calvinism means for the so-called house churches of a Christian community in a northern Chinese city, and what kinds of change the importation of Reformed theology has brought to Chinese house churches. Various significant accounts have addressed this development in China generally. My analysis complements these accounts by focusing on a small number of interconnected house churches in one city, and uses this case study to highlight interpersonal and organizational issues arising from the Calvinist approach.
\end{abstract}

Keywords: Christianity; Reformed church; Calvinism; urbanization; theology; China

\section{Introduction}

Over the past decade, Reformed Christianity broadly based on the theology of Calvinism has spread widely in China (Brown 2009; Chow 2014a, 2014b). Descriptions of Calvinism vary greatly, often according to context. The flourishing of Chinese Calvinism has drawn the attention of the media and scholars (Brown 2009; Chow 2014a, 2014b; Chow 2018, pp. 97-114; Fällman 2009, 2012; Ma and Li 2018, p. 120; Fulton 2015, p. 37).

This paper views Calvinism from a Chinese perspective in the context of modern China, especially the country's rapid urbanisation. Calvinist theology is often associated with the process of urbanisation. It is claimed that European Calvinism thrived in cities and so constituted an urban ideology (Kingdon and Linder 1970, p. xi). This may stem from the positive early support that Jean Calvin received from such cities as Basel, Strasbourg, and Geneva and other urban areas. How does this claim compare with Calvinism in Chinese cities?

Chinese Calvinism is indeed urban, insofar as it draws on urban educational and literacy levels, which are higher than those found in rural areas. However, Berger (2013) observes that Pentecostalism has also spread worldwide under urban conditions, especially in Latin America and Africa. In China, a mainly rural, Pentecostal-like form of Christianity (not, however, identified as Pentecostal by 
believers) involves speaking in tongues, presenting 'miracles', and emphasising emotional expression (Kang 2016). But it has not taken root in the cities. Rather, it is a form of Calvinism which is thriving in China's megacities and other urban areas.

It is true that both forms of Christianity seek the betterment and self-advancement of individual believers, including enhanced education, especially for children. They also both emphasise the high importance of community interaction, care for the family, and personal welfare. But urban Calvinism has forcefully rejected the rural Pentecostal-like counterpart, with urban believers valuing education above what they regard as rural 'superstition', which to them is incompatible with China's march towards so-called modernisation and technological supremacy. Since this urban-based 'progress' is seen as male dominated, the contrast between the two forms of Christianity is also gendered.

In Pentecostalism, women are the most active and expressive members of the congregation and are the power behind the few male church leaders. In the Chinese Calvinist churches, however, men provide the disciplinary drive at all levels. They impose strict rules about learning doctrine and seeking 'truth', and are the prime judges of theological correctness and church morality. Women are less prominent, expected to play roles as helpers and assistants in church and family.

Rapid and extensive urbanisation in China, the country's extraordinary technological, educational, and politico-economic international rise, and the work and personal discipline needed to achieve it within a few decades have filtered down to its population, including its urban Christians whose turn to Calvinism reflects this advance, which is commonly seen as largely led by men.

Some believers claim that their Christianity is a distinctive form of 'Calvinism with Chinese characteristics' $^{1}$. This raises the question of how similar or otherwise are Chinese and European Calvinism. Many religious movements worldwide claim to be Calvinist and use this label to identify themselves as either different from or as allied with others. When we look at individual cases of groups calling themselves Calvinist, we often find that their differences of belief and practice are shaped by the different contexts in which they occur. Given the crucial importance of these varying contexts-in China's case, its rapid urban population growth — this paper is therefore opposed to beginning analysis of Chinese Calvinism from an intrinsically religious viewpoint and starts, instead, from the interaction of its practitioners with the specific circumstances of China's Christian history.

In the late nineteenth and early twentieth centuries, Western missionaries set up Presbyterian churches in parts of China. In some, such as Fujian Province, they may still have some influence. However, what we may call the recent or New Calvinist wave has developed largely independently of this early Western form of Reformed Christianity. The new wave of Reformed theology, or Calvinism, was introduced into China through two channels. The first is overseas Chinese, especially via theological seminaries in Singapore, Malaysia, and Indonesia. For instance, preachings of the famous Reformed pastor Stephen Tong (唐崇荣) have been widely disseminated online among Chinese Christians. Second, Calvinist theology has been introduced by Korean missionaries who have established theological seminaries mainly in cities in North China. This has resulted in more and more Chinese church leaders becoming proponents of Calvinism and converting their churches to Reformed status. My research focuses on the latter.

Associated with China's extensive urbanisation is the rise of modern Chinese intellectuals with urban-produced aspirations of literacy and modernity. For such intellectual Christian leaders, the evolving Chinese version of Calvinism is much more sophisticated than other, usually earlier and rural, forms of Christianity, which depend less on literacy and the use of key texts. Calvinist theology meets their demands by providing a comprehensive understanding and interpretation of doctrine, a large amount of literature on how to practice Christianity in everyday life, a well-structured belief system, and a systematic, Presbyterian-like method of organising and governing churches.

1 The term "... with Chinese characteristics" is widely used to refer to the unique institutions or practices of Calvinism in China, thus distinguishing it from Calvinism elsewhere. 
Unlike most published work on Chinese Calvinism, which highlights public intellectuals and politically high-profile elites (e.g., Chow 2014a, 2018; Fällman 2012), this paper focuses on a grass-roots and low-profile community in what I will call City $\mathrm{A}^{2}$ in North China and its Pastor Liu, and analyses through case material how a distinctively Chinese form of Calvinism is shaped by its dissemination in China through global connections. The Chinese Calvinist primacy placed on 'rational' or 'intellectual' theologically-based belief does not necessarily mean that the faith is spread only by church leaders regarded as public intellectuals. Indeed, although Alexander Chow (Chow 2014a) attributes the spread of Christianity to the role of public intellectuals-including students and activists, some of whom are linked to those involved in the Tiananmen Square movement of 1989 and so have implicitly challenged the government-he concedes that such people are a very small minority of the Christian population. Fredrik Fällman's research is also based on Chinese Christians who are public intellectual elites, like the writer and critic $\mathrm{Yu}$ Jie and the bestselling author Bei Cun, and the politically high-profile congregation Fangzhou (the Ark) in Beijing. He also claims that, among such public intellectuals, "major actors here are overseas Chinese and Mainland exiles" (Fällman 2012, p. 157). Notwithstanding the possible indirect influence of domestic and overseas public intellectuals' ideas, the house churches I have studied in North China are neither led by public intellectuals nor, as far as I can tell from first-hand observation, directly influenced by them, even though these churches emphasize the importance of basing their belief on what they call a 'rational' and 'intellectual' theology.

It is true that urban house churches are generally led mostly by educated church leaders, but very few can be called public intellectuals, as distinct from having a view of their work as requiring an intellectual perspective. I would modify Fällman's observation and would instead claim that the major factor in the spread of Calvinist theology is the grass-roots Christian network in mainland China, and that this supersedes the influence of overseas Chinese or politically high-profile public intellectuals. It is precisely because of the low profile resulting from their discreetly dispersed yet expanding network gives them that Christian house churches do not normally attract the attention of media or government and so can grow quietly and quickly.

For many people who migrate to, or spend their lives in, urban areas, Calvinist churches provide not only a community-like surrogate family, but also a 'life system' that offers clear answers for everyday problems arising from marriage, parenting, work, and self-development. These issues used to be the responsibility of the Communist Party's danwei (work units) before 1979, or of families in villages. But now, there are no urban institutions catering to such problems. Let me now describe in more detail the activities of, and influences on, Chinese Calvinism.

The method of empirical observation in the fieldwork on which this paper is based is that of anthropological participant observation, and both structured and unstructured interviews, during various periods of a few months each over ten years. For reasons of anonymity, the particular areas of study are not given but are in northern China. The church chosen for the study is part of a huge network based on a theological seminary which is very influential in northern China. The aim of this article is to focus on a case of Chinese Calvinism but not to do a comparison of other forms of Calvinism within or outside China.

\section{Case Study}

In September 2017, a remarkable event happened in the expanding modern history of international Christianity. A group of Chinese Christian pastors made a pilgrimage to Germany, where Martin Luther lived and proclaimed his Ninety-Five Theses, so founding the Protestant Reformation, which spread across the world and is now very important in China. The event is remarkable because the group of Chinese pastors did not just visit these places as shrines. They used the occasion to reflect deeply on Christianity in the world and on the future role of a newly emerging and distinctive Chinese Calvinism.

2 For reasons of anonymity, the city's name is not disclosed. 
This distinctiveness is evident in the four reasons for this trip, summarised by the delegation's head, Pastor Liu:

1. To get a deeper understanding of the Christian Reformation by visiting the birth- and workplaces of Martin Luther and John Calvin.

2. To try to understand why Christianity in modern Europe appears to have undergone a decline. (In Pastor Liu's words, a 'degeneration' [眭落 duoluo]. His conclusion is that 'theological liberalism' is to blame, especially in Germany, regarded as the stronghold of liberal theology. The implication is that Chinese Calvinism has the discipline to resist such decline.)

3. To observe the development of Islamisation in Europe, especially since the entry of a large number of refugees from Islamic countries beginning in 2015, and to see whether it has been accelerated by this influx.

4. To establish contact with Chinese Christian organisations and churches in Europe, in order to support and facilitate their help for each other. (Pastor Liu was interested in sending short-term missionaries to Chinese churches in Germany.)

Pastor Liu is the leader of the Gospel Church in City A, having been ordained in 2011. I first met him in autumn 2006. Since 2005, he had been studying at the Grace Theological Seminary (otherwise known as the Korean Calvinist Theological Seminary) and managing the church, spending three months in the seminary and then carrying out shepherding tasks for three months within the church. He did this for four years. By 2008, the Gospel Church had about three hundred followers in six gathering places (聚会点 jühui dian) in City A; but in 2003, when Pastor Liu took over its leadership, it had only fifty-seven members. He described the church's development as follows:

"The church was founded in 1990 by Brother Zhi, who worked in tourism and often hosted foreign Christians. He had contact with American churches. They were Pentecostal. They offered Brother Zhi 2000 RMB a month, and he rented an apartment in City A for gatherings. The place became a tourist spot for American groups, who came here to worship and at the same time visit this Chinese house church. I came to the church in October 1999. At that time, the church was open to everyone. Foreigners could preach in the church if they wanted to do so. When there were no foreigners to preach, we ourselves could all do so, for everybody was allowed to preach. There was no theology. The pulpit of the church was chaotic [讲台很混乱 jiangtai hen hunluan]. Provided you were Christian, you were allowed to preach. Even people from Eastern Lightning [东方闪电 dongfang shandian] could preach. Nobody felt there was anything wrong about this. Even someone suffering from a mental disorder could preach. During a holiday on 1 October 2002, a pastor from the United States preached and, for some days, led the church in dancing and singing loudly. A neighbour reported this to the police, who came, banned the church and dispersed the church members. At the time, we had three gathering places, but we closed them out of fear. Instead, we separated into six small, inconspicuous groups [小组 xiaozu]. At the 2003 Spring Festival, we had a meeting of six co-workers, three of whom composed a letter accusing Brother Zhi. Their main objection was that Brother Zhi put the church in danger by keeping in regular contact with foreigners, which the government was strictly opposed to and would watch for. In receiving one foreign group after another, Brother Zhi was regarded as having made things impossible in City A. But Brother Zhi's vision was to 'entertain strangers,' and so he agreed to leave the church, whereupon the co-workers then recommended and elected [推选 tuixuan] me as convener [召集人 zhaoji ren]. From then until now [March 2010], we have had no major split in the church. In October 2003, the retreat meeting of the entire church had fifty-seven people."3 
This interview took place in 2010, at which time the church had four hundred members. In 2017 it had about one thousand. Following Pastor Liu's description in the interview, we can see that the procedural style of the church prior to 2003 was quite free and seemingly egalitarian, with anyone entitled to preach at will. This situation changed completely after Pastor Liu started studying in the theological seminary. Calvinists generally regard the pulpit as holy and allow only properly theologically-trained people to preach. I was told that the sermon delivered from the church's front area represents the words of God and therefore has great power, and it is certainly no longer the case that just anyone is entitled to preach at the pulpit. The entitlement to preach, zhan jiangtai (站讲台), has become more and more limited and the actual preaching made more demanding. At the same time, its limited accessibility has given it greater value and made it more and more desired by many male Christians for the honour it bestows, since it means recognition by churchgoers and achievement within the Christian circle. While there were no special requirements earlier to preach in the church, years of training are now needed to be regarded as able to zhan jiangtai. The former style was quite common among Chinese house churches in the past, supported by the understanding that everyone is equal and therefore has the right to talk about his or her belief in front of other Christians.

In describing the earlier form of church organisation as 'chaotic' (混乱 hunluan), Pastor Liu and other Gospel Church Christians convey two senses of the term: The absence of theology or a 'rational' concept of biblical truth, and the absence of a clear organisational structure in the church.

\section{A Concept of Biblical Truth}

The house church adherents did not begin with their belief based on a concept of biblical truth or knowledge of theology (对真理不清楚 dui zhenli bu qingchu). In fact, as I have indicated elsewhere (Kang 2016), the traditional Chinese house churches that I have observed previously tended to be 'anti-intellectual' and to reject theology in favour of charismatic leadership and the performance of miracles. The first task for Pastor Liu was to change this aspect of the Gospel Church. From 2006, he gave a series of sermons focusing on the importance and necessity of theology. As a result, the whole church changed. Younger believers, in particular, did not relate to the traditional Chinese Christian beliefs and so fully supported Pastor Liu and were eager to study theology themselves. Studying in a seminary is regarded as only for those who are committed to God's calling and to being a full-time servant (全职侍奉 quanzhi shifeng). For most congregants, the Gospel Church offers courses according to level of belief and church commitment. For instance, 'disciple training' is for those who have shown commitment to the church for more than three years and are regarded as potential group leaders, missionaries, or preachers. This challenging training is led once a week, by Pastor Liu himself, and usually lasts two years. The second level of training is a short but intensive program aimed at producing Sunday school teachers or imparting evangelising skills. Recently, the Gospel Church set up a one-year theological training and catechism class, and so now covers a range of training possibilities.

Each Sunday worship includes a sermon at least forty minutes long. Weekly Bible study among small groups of co-workers focuses on the Westminster Shorter Catechism and the Heidelberg Catechism. The church is thus something of an educational institution, with training and learning regarded as essential, not only for conveying biblical truth, but also for building a community of members within the church. They study together, share their thoughts with each other and, in their own words, "grow together". Moreover, Pastor Liu sees himself as having taught believers how to distinguish what he sees as heterodoxy or heresy from true belief. He puts such other beliefs into three broad classes or levels.

First, there are religions that he identifies as paganism (异教 yijiao): “With regard to such other religions, including Buddhism, we respect and understand them as culture. However, we also believe that they are paganism and used by Satan to delude people. I once asked a church member what he thought of Buddhists. He said, 'What do you think of them? Of course, they are possessed by evil spirits'." This attitude of some years ago has been extended to Islam over the past five years. 
Second, there is “heresy" (异端 yiduan), as instanced by the sect named Eastern Lightning (东方闪电 dongfang shandian) and the so-called Shouters (呼喊派 huhan pai). Their practices are regarded as based on false beliefs, and they must be watched and kept at arm's length, in order to prevent hidden heretics who pretend to be Christian from splitting the church-in fact, the Gospel Church takes particular care to keep an eye on such so-called heresy. Thus, any church member judged to be a heretic must immediately abandon their heretical belief and follow only the teaching of the Gospel Church, or be expelled.

Third, there are extreme cases of churches (极端 jiduan) whose focus on the Holy Spirit extends to speaking in tongues and working through spiritual dreams and healing and/or emotional expression, especially weeping. Those who used to speak in tongues have now stopped doing so in Chinese Reformed churches. 'Pentecostalism' is, in this way, generally subject to Calvinist criticism.

Overall, there is a clear push for individual church members' beliefs to be more integrated into a collective 'understanding' of the Bible, with the community of believers itself becoming more exclusive. According to Brother $\mathrm{Su}$, a group leader of the Gospel Church, "Through learning, brothers and sisters understand biblical truth more clearly. Therefore, we are able to distinguish and identify heretical beliefs and evil doctrines [异端邪说 yi duan xie shuo] and not be plundered by them. Now we are all of one mind to build our church." This unity and uniformity of belief is seen as achieved through years of learning and studying. Brother Su continued, "Building the church on the biblical truth is very important, because people coming from heresy often come and encroach on the church. Recently, two of them came to our church. At the beginning we didn't recognize them. But soon they started expressing their opinions on WeChat, acting as great counsellors and leaders of this generation, claiming that to believe only in Jesus is not enough to be saved. I have kicked them out of our WeChat group [微信群 weixin qun]. They are very dangerous, since they are familiar with the Bible and often use citations from it. If our church members were not clear about the biblical truth, some would not agree with my action in kicking the heretics out. But now we have reached a consensus." ${ }^{4}$

\section{Calvinism with Chinese Characteristics}

Worldwide Calvinism has taken various forms ${ }^{5}$. Yet in discussion and definitions of Calvinism, it is not always clear what the term refers to. What kind of Calvinism does a community identify with, and what doctrinal features does it prioritize? As regards Chinese Calvinism, these questions can be answered only through the interpretations of Reformed church leaders and followers. There are broadly four such aspects.

\subsection{Attitude towards the Authority of the Chinese State}

The attitude of churches towards current political authority is always a controversial topic among Calvinist theologians. Andrew Brown (Brown 2009) suggests that Chinese church leaders use Calvinism as the basis of a theology of resistance to government. By contrast, the churches I have studied regard the Chinese Communist Party (CCP) government as God-given and therefore legitimate. They therefore do not oppose the authorities and do keep a distance from government. Chinese Calvinism is therefore not entirely homogeneous, but varies to the extent that churches follow political or evangelical directions. Churches do, however, have in common a similar internal authority system based on theology, morality, and obedience.

4 Telephone interview on 17 April 2017.

5 It should here be noted that Chinese Calvinism differs in some respects from that described by Hansen (2008) in his book "Young, restless and Reformed" about new Calvinists in the USA and some other parts of the world. For instance, the American style of preaching is depicted as exuberant compared with the more solemn Chinese style, and its churches more inclusive of other kinds of Christians compared with Chinese churches' exclusion of other denominations, especially Pentecostal. Secondly, American Calvinists emphasize 'happiness' as a major goal and not just the observance of doctrine, which is a priority for the Chinese. Comparison of such different forms of Calvinism would make an interesting but much larger project which is, however, beyond the aims of this particular study, which focuses on Chinese Calvinism. 
Pastor Liu distinguishes between two types of Calvinist church at present. One focuses on what he calls a cultural mandate (文化使命 wenhua shiming), with church leaders primarily interested in addressing political and social issues. He gives the example of Pastor Wang Yi, who was well known in China as a human rights lawyer and influential public intellectual. The second kind focuses on what Pastor Liu calls its evangelising mandate (福音使命 fuyin shiming), concentrating not on olitical activities but on spreading the gospel in China and abroad, especially among Muslims. This is the mission of Pastor Liu's own Gospel Church, in contrast to Chinese Reformed churches whose cultural mandate is to try to directly influence Chinese society by changing the sociopolitical climate.

In fact, some leaders of the second kind of Calvinist church identified by Liu claim that the best way to spread Christianity is not by challenging government on religious freedom in the wider political sense, but by keeping a low profile and staying underground. This necessitates small numbers of believers meeting in inconspicuous, small house churches, which Liu claims gives them the warm feeling of being surrounded by a small group of family members. It also facilitates a sense of belonging. Gospel Church members also avowed that dividing into small groups and meeting in different believers' households prepares them for any government crackdown on Christianity. They may be unable to have large meetings, but by being well-connected through these small groups or cells, they can remain active. They also take the view that being low-profile and rejecting visibly higher status can purify congregants and filter out those who do not truly believe. Confrontation with government is thus rendered unnecessary and, moreover, they believe that the authority of the Party and the government is given by God and therefore justified. According to Pastor Liu and his church members, the most effective way of changing the government's attitude towards Christianity is to pray for it.

Their major 'worldly' concern is, in fact, the influence of Islam, which they aim to stem by converting Muslims to Christianity. Because they avoid overt opposition to government and prefer to remain relatively hidden from the gaze of the authorities, changing government policy is not part of what they see as being their concern through God. On the contrary, Pastor Liu and his church network support the government in many ways. For example, news regarding government policy that controls Muslim activities is often posted in the Christian WeChat group. However, news of government destruction of church buildings is not reported. It is only in reading WeChat groups' discussions that one might form the impression that the Chinese government, in effect, supports Chinese Christian missionary work, through its policy of strict surveillance of Muslims. Various news reports of government opposition to radicalized Islam are interpreted by Christians as pointing to the fact that, unintentionally, government and Christianity share the aim of diminishing Islam.

\subsection{Rational Urban Theology Contrasted with Feeling-Based Christianity in Rural China}

I have illustrated in detail elsewhere (Kang 2016) how the rural-rooted house church has changed from emotional, feeling-based practice to an urban, rationalized form. The turn to Chinese Calvinism is certainly part of this transformation, in which feeling-based practice is discouraged and systematic theology becomes not only appealing, but also absolutely necessary.

At first sight, there appears to be some continuity of Confucian influence in modern Chinese Christianity, especially in its form of Calvinism, as for example its inherent authoritarianism. But there is no evidence for such direct influence in modern Chinese Christianity. It is true that early Christian converts were Confucian scholars during the Ming and Qing dynasties when Confucianism was the official ideology. Confucianism has, in fact, lost its influence under pressure from communism, especially the Cultural Revolution of 1966-1976. The massive Christian conversion taking place in urban areas since the 1990s results more from a search for a new moral and belief system aimed at filling the so-called 'spiritual vacuum'. Alongside this development of authoritarianism, the modern transition in China from the Pentecostal-like rural form of Christianity to the urban emphasis on doctrine and institutionalized Calvinism does indicate a rationalization process of disenchantment similar to that described by Weber for Europe. 
Korean Christianity has been regarded as incorporating Confucianism, as with other aspects of Korean society. To the extent that Chinese and Korean Christianity share similarities as a result of Korean missionary influence, this results from the importation into Chinese Christianity of the whole Korean Reformed Christianity package, rather than directly from past Chinese Confucianism.

When I asked Pastor Liu the reason for the popularity of Calvinist theology in China, he said it is because "Calvinism is based on the Bible and has been formed into a total belief system that includes reason, consequences, and action. It is a systematic and complete world view. The life of belief is first of all about the inner self, which then affects one's behaviour or actions. Such belief involves changing one's views of life, the world, and values [i.e., the three views, 三观 sanguan]. This is what the Bible says one must do. Reformed theology comprises the three views conveyed by the Bible and delivers a rational belief system that is very appealing to Chinese intellectuals. This is because intellectuals do not want to believe in a religion that they don't understand. They want to know what it [Christian belief] is and why they should believe in it."6

While believers at traditional, rural-based churches read only the Bible, Reformed churches in urban China closely follow Christian catechisms or creeds such as the Westminster Catechism, the Heidelberg Catechism, the Westminster Confession of Faith, etc. They often make a public statement of their faith by hanging on the church wall examples of such creeds signed by all the church members or the group leaders of the congregation. Pastor Liu's congregation hangs the Westminster Confession of Faith on the wall at all their meeting places. Instead of studying just the Bible every week, as they once did, Gospel Church members have now studied the Westminster Catechism for three years. Their aim is to unify the church theologically and prevent it from splitting.

However, the turn to Calvinism has had a price. Since it is commonly believed in traditional house churches that the Bible is the only scripture and should be the exclusive focus of study, the addition of catechism caused a great disagreement among church members, especially those who had been leaders in traditional house churches. The dispute often arises over the question of how to understand God's will. For Pastor Liu, this is possible only through learning "the truth" in the doctrine conveyed by catechism, while members from traditional house churches often interpret God's will based on feelings received from God. This is the main reason for the Gospel Church's split.

According Sister Yi, one of the six main church leaders at the Gospel Church, God Himself directly led her on her way, even giving direct instruction in preaching. "God picked many preachers in our church, 'moving' them Himself. We just prayed and read the Bible. We didn't have any reference books or other materials. Everything was taken from the Lord Himself. This was direct guidance by the Holy Spirit. For example, when we prepared some preaching, God would not only give the title of the sermon, he would also reveal the relevant Bible verses which would be interwoven with the preaching. When we kneeled before God, He would just write the entire sermon in our hearts. Even some teachers from a theological seminary admired us. Although we didn't receive any formal theological training, our interpretation of the Bible was acceptable, all of which was taught by the Holy Spirit. We didn't understand theory, but we knew how to practice."

In 2002, Sister Yi came from what I will call City H in North China to City A and joined the Gospel Church. Her viewpoint was in direct contrast to that of Pastor Liu. She complained, "Pastor Liu always claims that I am emotionally oriented [i.e., not 'rational']. But that is not true." Their different views of the necessity of formal or 'rational' biblical teaching for understanding ended up splitting the church, with Sister Yi leaving along with dozens of believers. There was another reason for Sister Yi's departure. She was dedicated to preaching and giving sermons in church, and was regarded as a gifted preacher. But the Reformed church is strictly opposed to women preaching. Sister Yi became upset at co-workers' meetings when the issue of women preachers was raised and declared unacceptable, the rationale being that wives are supposed to be obedient to their husbands. In the past at the Gospel

\footnotetext{
6 Interview on 22 September 2017 in Germany.
} 
Church, some co-workers were female, but now almost all are male. Women are expected to help men in the church and the family.

The split was indeed a body blow to the church, but also a watershed in its development. One of the believers who was close to Sister Yi told me sadly, "The major change of the church was the departure of Sister Yi. It was painful to see them [Sister Yi and Pastor Liu] separated and at loggerheads with each other. Sister Yi gave me a lot of love and care. When I had trouble in my life, she was there to comfort me and pray for me. However, before Calvinist theology entered our church, I only pursued the feeling of being moved [感动 gandong], which is kind of egocentric. There was a kind of spiritual arrogance, that I am more spiritual and therefore better than other people. If I did not have the feeling of being moved, I would think of the scene of the crucifixion of Jesus that makes me weep. I felt like I should weep. When I saw the kids at our Sunday school not weeping while watching the movie The Passion of the Christ, I was very angry with them. I could not accept the weakness of other people and lacked mercy, since I didn't realize the nature of sin and relied only on my own efforts. Now I am much clearer through the truth of God and have no doubts as to whether I have been saved by God. My hope is based on God's words, which will never change and which helps me through low periods. I have become more objective and humble. In the past, I only focused on my own spiritual life and didn't have a sense of the kingdom of God, and of the gospel and mission."

\subsection{Hierarchical Church Organisation, Male Authority and Authoritarian Leadership}

It is well known that different definitions of Calvinism may emphasize different aspects. American Calvinism advocates an egalitarian church organisation, unlike Chinese Calvinism's penchant for hierarchy. Lacking this egalitarian approach, and consistent with its avoidance of confrontation with government, Chinese Calvinism does not encourage the introduction of Western democracy in China (though see Niebuhr (1937) for an early discussion of how Christianity in the USA can become involved in politics). Whether or not Calvinism can be regarded as a source of democracy is indeed a controversial question (Kingdon and Linder 1970). Even Calvin himself is a controversial character. Although possibly prejudicial, the worst image of him is presented by the Austrian author Stefan Zweig in his book The Right to Heresy: Castellio against Calvin. Many scenes in this book describe how Calvin took power and incited violence in Catholic churches, so reminding one of the Cultural Revolution in China. It is clear that different kinds of governance, both democratic and authoritarian, can stem from Calvin and Calvinism according to varying social and political circumstances.

We may note here the observation by Gwendolen Carter in her Politics of Inequality that "from the political point of view it is significant that Calvinism is inherently authoritarian ... Where Calvinists have fought for freedom of conscience, it was due to circumstances rather than their theology" (Carter 1958, p. 273). Chinese Calvinist churches are indeed individually and internally run by authoritarian pastors, for, since there is no China-wide Presbyterian-like structure of senators and elders managing the church, they are thus not subject to higher authority and have a great deal of power. The co-workers who take care of the church's everyday activities are personally selected and trained by the pastor. They are loyal to the pastor and follow his or her decisions. Therefore, the pastor's authority is based not on his or her theological knowledge, but, most important, on these personal relationships, which have been strengthened through years of care and training.

Before Calvinism, there was no clear structure of Chinese church leadership. Church co-workers arose 'naturally'. There were no set rules regulating or managing them. Whoever initiated and attended to church activities was entitled to be a church co-worker or leader. Sister Yi, for example, started to preach only forty days after her conversion in 1988. She excitedly spoke of the first time that she was invited to speak before believers at a house church in City H: "One day, Sister Qin [a co-worker in Sister Yi's church] asked me, 'Sister Yi, can you say something?' I was so happy, since I had been longing for it. I said yes. On that day, I really wanted to speak. I felt that I had a lot to say. I had no fear of standing in front of many people. I was full of joy. But my first preaching lasted only ten minutes. I had expected to be given much longer, since I felt I had so much to say. It was my first preaching." 
Sister Yi soon became one of the major co-workers in her church in City $\mathrm{H}$, later retiring early so she could preach full-time. Likewise, as we saw above with Pastor Liu, he was not systematically elected, but rather chosen by the church leaders, informally agreed among six co-workers. Such cases can be found often in other places in China: Church leaders emerge naturally without formal election, in the absence of set standards or procedures, especially in rural areas.

A major criterion conventionally defining a Calvinist church is whether or not it practices Presbyterianism - that is to say, has a structure of government in which elders form the church management (Baugus 2014). The Gospel Church found it extremely difficult to reform its leadership to consist of a plurality of elders and, at the same time, to form a presbytery with other local churches. However, Sister Yi's departure was the first step in facilitating this possibility, for it removed her preference for unstructured leadership. Since then, Calvinist, theologically-based faith has encouraged further development in this direction. The number of church members has increased from five hundred in 2011 to one thousand in 2017, distributed throughout twelve gathering places that all have the same teaching content and management style. To be able to practice Presbyterianism, the church has needed to establish a membership system. This means applying a set of rules to decide who is entitled to be a formal member and who is not. Only those with formal membership have the right to vote for elders. Because some Chinese house churches instead adopt a form of Presbyterianism. Pastor Liu has spent a long time training believers to accept and support the stricter concept that he believes in, but he still cannot achieve the complete transformation of the church. For many Chinese Reformed churches, like the Gospel Church, the Presbyterian structure is an ideal version of organisation that they are trying to reach.

\subsection{Calvinism as a Life System-Obedience and Morality}

A former prime minister of the Netherlands, Abraham Kuyper, presents Calvinism as a life system, a systematic world view comprising three important relationships: Between humans and God, between humans, and between humans and the world (Kuyper 1931, p. 9). To what extent does Chinese Calvinism share this view?

First, Chinese Calvinism differs from the early European version in that its followers are not uncertain about their salvation. Indeed, they are sure that they are saved because they regard their lives as predestined by God alone. When asked whether they are sure of their salvation, they often quote Romans 10:10: "For with the heart man has faith to get righteousness, and with the mouth he says that Jesus is Lord to get salvation." It is thus unlike Weberian Calvinism, in which an individual's salvation is not certain, meaning that he or she must constantly seek the evidence of salvation by working hard and achieving economic success in response to God's calling. Such reassurance is also important for churchgoers in urban China, because it provides them with clarity in dealing with the uncertainties of everyday urban life.

Second, Chinese Calvinist theology emphasises discipline and obedience to pastors, normally without much debate regarding theology or church management. Those who do not support the pastor's theological viewpoint are gradually marginalized and may even leave the church, as the case of Sister Yi shows. The relationship between pastor and main co-workers is similar to that between master and disciples in a traditional Chinese Buddhist temple.

Moreover, because Chinese Calvinist theology encourages hard work for the sake of God and sees no wrongdoing in earning money through Christianity, provided that one-tenth is contributed to church or missionary work, many Christian companies promoting religious tourism have emerged in China. On trips to Israel, Christians visit the birthplace of Jesus and the places where he worked, with the aim of getting a deeper understanding of the Bible. According to one report (Hinsdale 2017), in the first seven months of 2017, sixty-four thousand Chinese travelled to Israel. In the past ten years, Chinese Christian tourist companies have broadened their itineraries to include Turkey, Egypt, Korea, and parts of the Mediterranean where Paul was a missionary, as recounted in the Acts of the Apostles. Chinese Christian tourism thus plays a role in global connectedness and reinforces Christians' beliefs. 
Finally, despite being already saved, Chinese Calvinists are expected to reshape their world view, particularly by reassessing their life and values. There is thus a heavy emphasis on morality and a puritanical way of life. Early European "puritanism" has, in fact, become something of a role model for modern Chinese Calvinists based on a strict doctrine and moral code. In not cultivating an overt political outlook, Chinese Calvinism focuses inwards, on the personal aspects of a moral life such as honesty, obedience, filial piety, and the value of marriage. Church leaders tell their congregations to follow the so-called moral law (道德律 daode lii) of leading a moral and pure life, regarded as gratitude for God's salvation.

Pastor Liu likened this emphasis on morality to the Puritans' insistence on honesty and obedience in sixteenth- and seventeenth-century Europe. The teaching or guidance of moral behaviour stems from the Ten Commandments, which relate people to God. Pastor Liu remarked, however, that the main challenge to Chinese urban churches arises from sexual behaviour, especially premarital sex and extramarital affairs. He sees this as undermining marriage and the family, with Chinese society becoming more and more tolerant and accepting of such 'deviant' behaviour.

\section{Conclusions}

Since its pastor studied at the Korean Calvinist Theological Seminary, the Gospel Church has changed dramatically. First, it has undergone internal reform and external expansion, resulting in a dramatic change of theological approach and organisational structure from those of the previous house churches. In focusing on a 'rational' or 'intellectual' theological doctrine, it rejects 'heresy' and the earlier Pentecostal character of Christianity in China. Second, since there is no China-wide management structure of senators and elders, as in standard Presbyterianism, the individual pastor has much more power than if he were subject to a higher authority. Finally, the Calvinist insistence on engaging with worldly matters without confronting government is evident in the church's drive to peacefully convert Muslims, a goal that unites and motivates church members. Since its split in 2011, the Gospel Church has been growing dramatically, aided by its rejection of heresy and its policy of not confronting the government, both of which appeal to urban Chinese.

Arising out of this conclusion, there is a possible agenda for future research. Thus, while China's rapid urbanisation is bringing about major social changes, there appears to be some continuity with past organisational and behavioural expectations and pressures. We can ask, for instance, how significant is it that modern Chinese Calvinism shares some broad features with early Communism:

(a) religious/ideological emphasis on puritanical morality, such as loyalty to authority (Party, God, church leaders), honesty, and sexual morality;

(b) totalitarian organisational authority of leaders, with churches constituting active, efficient, and flexible cell units (such as Bible study groups) partly echoing the functions of the now defunct Communist danwei;

(c) dependence on a holy script or written dogma;

(d) opposition to liberalism (religious and political, respectively);

(e) potential to be a revolutionary force.

How much does the dissemination of Calvinism depend on this continuity?

Funding: Research was funded by the Max Planck Institute for the Study of Religious and Ethnic Diversity, Goettingen, Germany, where the author is a fellow.

Acknowledgments: The author acknowledges with thanks comments made by Peter van der Veer, Kenneth Dean and participants at the workshop on "Chinese Religions in the Age of Massive Urbanization" on 6-7 of June 2018 at the Max Planck Institute of Religious and Ethnic Diversity, Göttingen, Germany, where the paper was presented.

Conflicts of Interest: The author declares that there is no conflicts of interest. 


\section{References}

Baugus, Bruce P. 2014. Introduction: China, Church Development and Presbyterianism. In China's Reforming Churches: Mission, Polity, and Ministry in the Next Christendom. Edited by Bruce Baugus. Grand Rapids: Reformation Heritage Books, pp. 1-23.

Berger, Peter. 2013. Peter Berger on the Explosive Growth of Pentecostalism. Video, 5:22. February 5. Available online: https://www.youtube.com/watch?v=0tGXBuYXpwk (accessed on 25 May 2018).

Brown, Andrew. 2009. Chinese Calvinism Flourishes. The Guardian. May 27. Available online: https://www.theguardian. com/commentisfree/andrewbrown/2009/may/27/china-calvin-christianity (accessed on 20 May 2018).

Carter, Gwendolen M. 1958. The Politics of Inequality: South Africa since 1948. New York: Praeger.

Chow, Alexander. 2014a. Calvinist Public Theology in Urban China Today. International Journal of Public Theology 8: 158-75. [CrossRef]

Chow, Alexander. 2014b. New Calvinism in China? Posted on May 22. Available online: http://www.cswc.div.ed. ac.uk/2014/05/new-calvinism-in-china/ (accessed on 15 May 2018).

Chow, Alexander. 2018. Chinese Public Theology. Generational Shift and Confucian Imagination in Chinese Christianity. Oxford: Oxford University Press.

Fällman, Fredrik. 2009. Chinese Christianity Is More than Calvin. The Guardian. June 6. Available online: https://www.theguardian.com/commentisfree/belief/2009/jun/05/religion (accessed on 15 May 2018).

Fällman, Fredrik. 2012. Calvin, Culture and Christ? Developments of Faith among Chinese Intellectuals. In Christianity in Contemporary China: Socio-Cultural Perspectives. Edited by Francis Khek Gee Lim. London and New York: Routledge, pp. 153-68.

Fulton, Brent. 2015. China's Urban Christians. A Light That Cannot Be Hidden. Eugene: Pickwick Publications.

Hansen, Collin. 2008. Young, Restless, Reformed. Wheaton: Crossway Books.

Hinsdale, Mason. 2017. China Is Israel's Fastest Growing Tourist Source Market, Growth Fueled by 'Religious History Buffs'. Jing Travel. October 13. Available online: https://jingtravel.com/china-is-israels-fastestgrowing-tourist-source-market-growth-fueled-by-religious-history-buffs/ (accessed on 20 May 2019).

Kang, Jie. 2016. House Church Christianity in China: From Rural Preachers to City Pastors. Basingstoke: Palgrave Macmillan.

Kingdon, Robert M., and Robert D. Linder, eds. 1970. Calvin and Calvinism: Sources of Democracy? Lexington: D. C. Heath.

Kuyper, Abraham. 1931. Lectures on Calvinism. Grand Rapids: Eerdmans.

$\mathrm{Ma}, \mathrm{Li}$, and Jin Li. 2018. Surviving the State, Remaking the Church. Eugene: Pickwick Publications.

Niebuhr, H. Richard. 1937. The Kingdom of God in America. Middletown: Wesleyan University Press.

(C) 2019 by the author. Licensee MDPI, Basel, Switzerland. This article is an open access article distributed under the terms and conditions of the Creative Commons Attribution (CC BY) license (http://creativecommons.org/licenses/by/4.0/). 


\title{
Article \\ Chinese Catholic Nuns and the Organization of Religious Life in Contemporary China
}

\author{
Michel Chambon \\ Anthropology Department, Hanover College, Hanover, IN 47243, USA; chambonmc@yahoo.fr \\ Received: 25 June 2019; Accepted: 19 July 2019; Published: 23 July 2019
}

\begin{abstract}
This article explores the evolution of female religious life within the Catholic Church in China today. Through ethnographic observation, it establishes a spectrum of practices between two main traditions, namely the antique beatas and the modern missionary congregations. The article argues that Chinese nuns create forms of religious life that are quite distinct from more universal Catholic standards: their congregations are always diocesan and involved in multiple forms of apostolate. Despite the little attention they receive, Chinese nuns demonstrate how Chinese Catholics are creative in their appropriation of Christian traditions and their response to social and economic changes.
\end{abstract}

Keywords: christianity in China; catholicism; religious life; gender studies

Surveys from 2015 suggest that in the People's Republic of China, there are 3170 Catholic religious women who belong to 87 registered religious congregations, while 1400 women belong to 37 unregistered ones. ${ }^{1}$ Thus, there are approximately 4570 Catholics nuns in China, for a general Catholic population that fluctuates between eight to ten million. However, little is known about these women and their forms of religious life, the challenges of their lifestyle, and their current difficulties. Who are those women? How does their religious life manifest and evolve within a rapidly changing Chinese society? What do they tell us about the Catholic Church in China?

This paper explores the various forms of religious life in Catholic China to understand how Chinese women appropriate and translate Catholic religious ideals. The first part presents the most ancient and resilient form of Catholic religious life in China, the antique model of the consecrated virgins-also named beatas - that has a long history within worldwide Catholicism and is still present in China today. Then, elaborating on two case studies, the second part investigates the alternate but dominant form of Catholic religious life, the model of the missionary congregations. These two models provide the benchmarks from which Chinese nuns reflect on the ways in which they adjust their position and contribution to the contemporary Church in China.

Data were collected from March 2015 to July 2017. From February 2016, I conducted 18 months of ethnographic fieldwork in Nanping City with extensive participant observation among the local Catholic communities (Chambon 2018). In addition, I did several short visits to religious communities and nuns who live in other Chinese provinces, and when it was possible, I spent a few days within their convents. I also interviewed Chinese and non-Chinese nuns and clergy members in Hong Kong, Taiwan, France, and the USA. These places, and a few others, play an important role in providing support and training to Chinese Catholic nuns. ${ }^{2}$ Based on this extensive data, this article elaborates on

1 See Religions \& Christianity in Today's China, 2018, Vol. VIII, No. 2, pp. 26-51, ISSN: 2192-9289, www.china-zentrum.de.

2 In more details, I have visited 12 relevant sites and collected information from more than 30 Catholic nuns and 10 priests and bishops. This research greatly benefited from the support and trust of sisters Janeth Caroll, Marinei Pessanha Alves, Theresa Shi Liwen, and many others who prefer to remain anonymous. Also, fruitful conversations with Pascale Sidi-Brette 
three cases only, namely Fujianese beatas and two religious congregations, in order to map out the spectrum of situations and practices I encountered.

This article unveils deliberations and transformations that Chinese Catholic nuns have recently witnessed, embraced, or resisted. ${ }^{3}$ Yet, the article also questions analytical assumptions about Catholic structures, gendered apostolate, and religious change in ways that nuance our perception of both female religious congregations and the Catholic Church in China. Our study suggests that despite a whole range of efforts and a strong desire to belong to the universal Catholic Church, Chinese nuns do not simply follow the standardized Catholic forms of religious life that encourages a collective pursuit of a unique 'charism' ${ }^{4}$ either within apostolic or contemplative congregations. Instead, Chinese nuns organize their religious commitment along a wide and evolving spectrum of practices that borrows from two traditional Catholic models, the beatas and the missionary congregations. Thus, their religious life fosters a multidimensional and changing apostolate combined with a search for autonomy from social and ecclesial institutions.

These findings speak to broader scholarly debates on Chinese Christianity. Researchers have long debated whether Chinese Christian communities tend to remain close to traditional Chinese forms of religious practices or to depart toward a more distinctively Christian religiosity (Gernet 1985; Harrison 2013; Lian 2010; Menegon 2009). For instance, while Menegon has explored how Chinese believers responded to new forms of Catholic practices and values introduced in seventeenth century Fujian (Menegon 2009), Harrison has highlighted how the Catholic piety introduced in a Chinese village was first perceived as similar to other Chinese religious practices and then evolved over time while taking distance from Chinese folk religion (Harrison 2013). At the core of these debates lays the question of how Chinese people respond and adapt to religious belief and practices that originate outside of the Chinese cultural sphere. Considering this conversation, Catholic nuns provide a vibrant case study through which one can observe how Chinese women appropriate Catholic religious institutions to shape and legitimize their own contribution to their contemporary Church and society. This article argues that the ways they cultivate a memory of these models that have shaped the history of their Church do not confine them into a mere mimesis but sustain their efforts in creating distinctive forms of religious life that can effectively face current challenges and difficulties.

\section{Part I: Consecrating Oneself as a Beata}

\subsection{Historical Roots}

The historical roots of female religious life in Catholic China have been the subject of recent studies and interpretations (Lutz 2010; Leung and Wittberg 2004; Menegon 2009; Entenmann 1996; Kang 2013). The earliest form was introduced by Spanish Dominican missionaries in seventeenth-century Fujian, and soon after, by French missionaries in Sichuan province (Leung and Wittberg 2004). Following the example of Petronilla Chen, a young Christian from Minding who pronounced vows in 1643, some Chinese women were invited by missionaries to embrace the ideal of consecrated life and celibacy in order to assist their Catholic community (Kang 2013, p. 31). They were becoming part of what the Catholic Church recognizes as the Ordo Virginum (Congregation for Institutes of

have been central in the elaboration of this paper. Finally, Francis Lim Khek Gee, the editor of this special series, and the anonymous reviewers must be thanked for the very helpful comments and suggestions they made.

3 In Chinese, Catholic religious women are recognized and named xiunï (修女). This term which can be translated as “women of cultivation, repair and construction" is both a title and a function. Unlike in other social circles where kinship terms (Elder Brother, Younger Sister) can be used in a symbolic and religious way, Catholic nuns are usually not called "sister" but xiunï. Thus, this article favors the term nun alone. Furthermore, this English term recalls proximity with Buddhist nuns, a proximity that most Chinese people use to apprehend what Catholic religious life might be.

4 I use here the term "Charism" as it is understood within the Catholic Church. It is different from the term "Charisma" as defined by Max Weber. In the Catholic Church, charism is usually applied to define the specific strength of a religious group, its unique and distinctive "gift" that unfolds through an apostolate and related spirituality. For example, see Congregation for Institutes of Consecrated Life and Societies of Apostolic Life 2018, p. 18. 
Consecrated Life and Societies of Apostolic Life 2018). In a primarily rural Catholicism facing social and political suspicion, these pious women often lived with their family in their home village, taking care of worship places, organizing the religious education of women, delivering baptism, and visiting and praying for sick people. By pronouncing private vows of chastity, poverty, and obedience, their religious lifestyle and function were not a physical departure from their community but a specific commitment to it. Yet, their chosen celibacy combined with their familial housing soon embedded an ethical and social challenge to the broader Confucian ideal (Menegon 2003; Harrison 2013, p. 63). Throughout the nineteenth and twentieth centuries, Chinese Catholic women were often perceived as a social abnormality, and in repeated cases, they were falsely accused of atrocious abuse of children (Young 2013, p. 4). Within the Church, beatas appeared as an anomaly to the modern and gendered Catholic ideal of religious life brought by nineteenth-century European missionaries (Tiedemann 2010a; Entenmann 1996). Through various and consistent efforts, missionaries encouraged these women to form standardized religious congregations recognized under canon law (Tiedemann 2010b; Mariani 2011; Li 2015, p. 25; Cai 2012, p. 59).

Nonetheless, this peculiar model of religious commitment still exists in contemporary China. Most of them are in Fujian province, one of the two places where this model took root in China. Nuns Shi and other informants from Northern Fujian estimate that there are about ninety official nuns and several hundred unregistered nuns praying for and serving Fujianese Catholic communities. Many unregistered nuns are very advanced in age and it is difficult to precisely estimate the scope of their action. Yet, there is not a radical rupture of religious lifestyle and ideals between registered and unregistered nuns. By renouncing married life and motherhood, by standing where they identify an ecclesial need, they devote themselves to the service of a Catholic community.

Today there are various ways to name these specific nuns who embrace religious life and engage in full-time apostolate without forming a religious congregation. The most common Chinese term to designate their religious commitment is zhennü (贞女), a woman who is loyal, faithful, chaste, virgin, and virtuous. In contemporary Xiamen, lay Catholics call these nuns gupo (姑婆), old aunt; in Shanghai, mumu (姆姆), teaching nurse; and in Fuzhou, yigu (依姑), depending aunt. Non-Christians may name them xiunü (修女), nun, or simply add a xiao (小), little, prior to their family name. These variations suggest that while these nuns are identified within their local community, the broader Church still struggles to foster a standardized and national label to recognize them and their service. This difficulty to name their specific roles within an evolving and diverse Catholic Church remains for historians and anthropologists who intend to discuss their contribution to the Church in China. Following the general trend of the literature produced by French missionaries in the nineteenth and twentieth centuries, today's scholars tend to uniformly name them virgin (Menegon 2003; Tiedemann 2010b; Harrison 2013; Li 2015; Cai 2012). Yet, the English term virgin tends to reduce these women and their current apostolate to what they do not do (marriage and sexual life), downplaying the broad reality of what they actually do and sidelining the fact that some of these women have been married at some point of their life.

To address this difficulty of naming and to echo contemporary practices and local traditions, the present article uses three terms to equally refer to this religious life: nuns, beatas, and consecrated virgins. The term nun - used in daily conversation-insists on their proximity with other Catholic nuns who belong to formal religious congregations. The Latin term beata follows the Spanish practice initiated in the seventeenth century by the Dominicans in Fujian and refers to consecrated women who intend to enact the Beatitudes. ${ }^{5}$ Finally, the term consecrated virgin borrows from the canonical vocabulary of the Catholic Church and dominant trends in the academic literature. By maintaining

5 This female ideal of embracing evangelical values through the Ordo Virginum and generating a distinctive social organization has a rich history throughout medieval and early modern period. For instance, see (Simons 2001). 
these three terms together, this article intends to further reflect on the rich reality of this Chinese religious lifestyle without limiting it to a single characteristic or to the past (Kang 2013).

The following section draws the portrait of one contemporary beata who lives and serves in Nanping City. Then, the article presents similarities and dissimilarities with other Fujianese consecrated virgins to better portray what entails this Chinese Catholic model of the beatas today.

\subsection{The life of service of Nun Shi}

Nun Theresa Shi Liwen is a beata who serves Catholic parishioners of Northern Fujian. Besides a small cross, she does not wear any distinctive religious clothing. With her cellphone, short hair, and neat outfit, she looks like many local women. Cheerful and strong-minded, most local parishioners and state officials know well who 'Shi Xiunü' is.

Born in January 1968, she grew up in Fuzhou, the capital city of the province, within a rather modest Catholic family. Unlike many consecrated virgins of the past, contemporary Fujianese beatas do not come from well-to-do families (Tiedemann 2008). In 1988, Nun Shi manifested her interest in consecrated life and spent two years of service in an urban parish. In 1990, the archdiocese of Fuzhou organized for her and eleven other young postulants a two-and-half-year training. These young women started to live together under the supervision of an old beata who had known the Church before the communist period (pre-1949). The archdiocese invited various professors and educators to offer multiple one-week training sessions on biblical studies, catechism, Church history, music, mathematics, English, politic, and medical care. According to Nun Shi, six groups were similarly trained from 1990 to the early 2000s. Since then, the declining number of postulants did not allow the training to continue. The few candidates were initiated and formed by a senior consecrated virgin.

In March 1995, after her two-and-a-half-year of training and a few years of pastoral service within a local parish in Fuzhou, Nun Shi agreed to move to Nanping to serve the northern part of the province. Soon after, the Chinese administration established a Catholic diocese there which overlaps the territory of the Minbei Prefecture. This rural and mountainous territory did not have any official priest or nun to serve local Catholics who were willing to form a properly registered Catholic Church. Thus, civil authorities were recruiting clergy members willing to permanently relocate from coastal areas to inland territories. Indirectly, the local government was officially recognizing and extending the apostolate of Nun Shi to the diocese of Minbei.

In 2017, the Minbei Diocese counts only nine priests and three beatas. Its territory covers the prefecture of Minbei that hosts 3.7 million inhabitants and a few thousand Catholics (Charbonnier 2014) (see Figure 1). However, most of them have refused to join the registered side of the Catholic church and belong to 'underground' communities. Those communities are ministered by the underground clergy of either Fuzhou or Fu'an. Those cities are the most dynamic place of Northern Fujian Catholicism. Thus, there is no single underground ecclesial unity that covers the Minbei Diocese.

In practice, official priests and consecrated virgins of the Minbei Diocese work in pairs. One priest collaborates with one nun in the service of one or several parishes. Every five years, the pairs are redefined to prevent problematic attachment between the two. A few years ago, there were eight beatas in the diocese of Minbei. But since then, one has decided to return to her native diocese, one got married, and one left for spiritual training. In the face of such vulnerabilities, Nun Shi is skeptical and wonders about the future of the local Church.

Nun Shi is currently collaborating with the diocesan administrator of the diocese, Father $\mathrm{Wu}$, an official priest who comes from Ningde. Together, they oversee two of the ten parishes of the diocese; Nanping and Wuyishan. While the Minbei prefecture is predominantly rural, Wuyishan is a famous touristic site attracting thousands of visitors, Nanping is a small but sophisticated city which fosters an unusual quality of living. The two parishes are two hours away from each other. Father $\mathrm{Wu}$ and Nun Shi usually spend half of their week in one, and the other half in the other. Each parish has one church recently rebuilt and a little more than one hundred Catholics. In both places, the underground community does not collaborate with the official Church. 


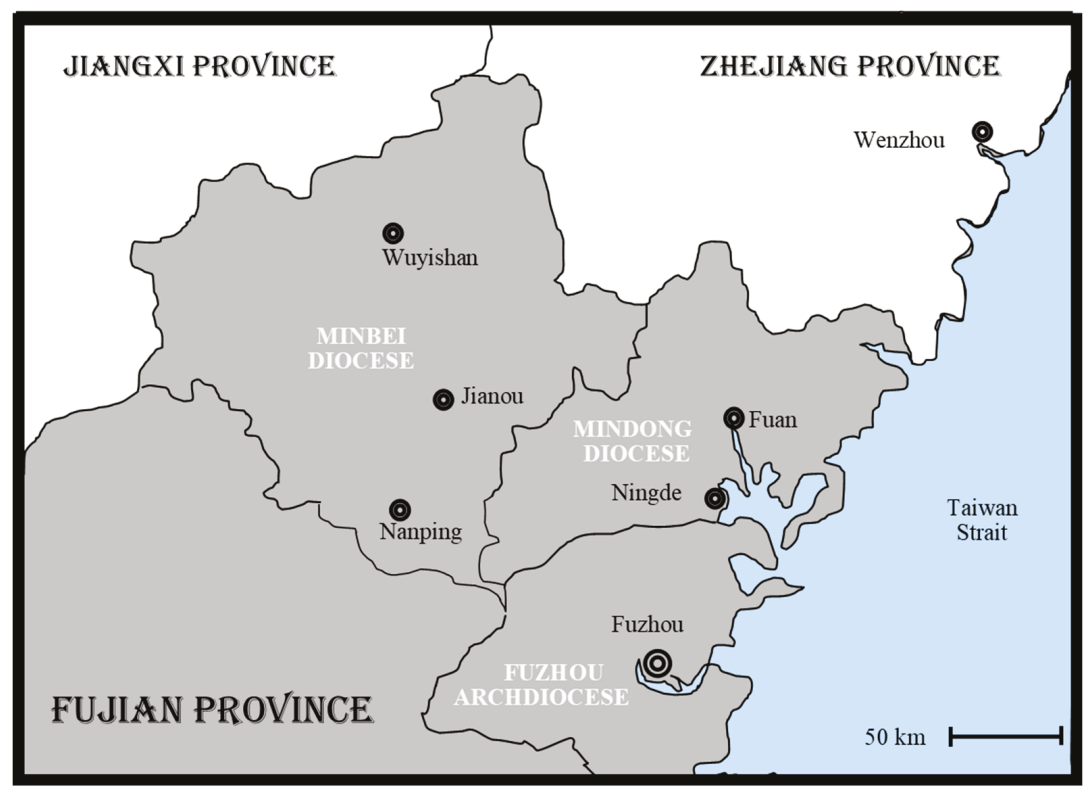

Figure 1. Simplified Map of Northern Fujian.

Since Father $\mathrm{Wu}$ is often called for meetings with state officials at local, prefectural, and provincial levels, Nun Shi is more present in the parish and oversees all practical matters and important decisions. Father $\mathrm{Wu}$ administers sacraments, takes formal decisions, and joins various meetings organized by state officials. When they are in the parish, Nun Shi makes sure that the church remains open and welcoming all day long. She schedules volunteer work for cleaning, decoration, and maintenance, as well as visits to elderly and sick Christians. During the recent reconstruction of one of the two churches, she supervised workers and made daily decisions such as defining the color of the new roof tiles. When the priest is present in the parish, she prepares the altar for the daily morning mass. She is also in charge of preparing families for baptism and marriage before they encounter the priest. When a Catholic passes away, she coordinates the traditional mortuary prayers that are said at home by other churchgoers and helps with organizing the rest of the funeral. In the summertime, she organizes camps for the few children and teenagers of the parishes but also monitors the seminarian who spends his summer for pastoral training in Minbei. Overall, nothing occurs in the parish out of her sight.

Since Nun Shi-like Father Wu-lives inside the dormitory of the church, she is close to parishioners and her real community of belonging is the local Catholic community. She shares the joy, routine, and concerns of the parishioners. Her apostolate supports and complements the pastoral action of the priest, and she also supplements for his recurrent absences. Through religious obedience and celibacy, Nun Shi and Father Wu share a common commitment to the well-being of their local Church. They both deploy complementary actions and efforts. In the eyes of their parishioners, Nun Shi is consequently not more 'virgin' and 'unwedded' than Father Wu, but both are similarly celibate and consecrated to the service of the Church.

In terms of financial sustainability, the beata and the priest both depend on parishioners' donations. They do not have a formal wage or salary. Yet, in the Minbei diocese, all parishes share a portion of their income to secure medical insurance for every single priest and nun. As we will see later, this is rather uncommon and most of the time, Chinese nuns are unable to secure enough funding to afford medical insurance. Therefore, Nun Shi considers that she lives in a rather comfortable and blessed situation. 
Three times a year, all the beatas of the Minbei Diocese gather for a few days. The location of these gatherings varies. When the diocese had more consecrated virgins, priests and nuns talked about building a small house where the beatas could gather and rest away from pastoral duties. This house would have been like a retreat center where each nun could come to relax and nourish her spiritual life. But since the nuns are scattered across the entire diocese, finding a proper location has remained under constant debate. Also, many local Catholics have argued that meager diocesan resources should be oriented toward the renovation or reconstruction of churches instead of the creation of a building that would remain empty most of the year. These lay Catholics also mentioned that this building might cut the beatas off their communities. Thus, they were reluctant to finance it and the project was finally abandoned.

Once every few years, Nun Shi joins relevant training elsewhere in mainland China and Hong Kong. In addition to the spiritual and practical formation, these meetings allow her to network with Chinese nuns who belong to various ecclesial structures elsewhere in China, and to appreciate the specificity of her religious service. Yet, Nun Shi considers that opportunities for local gatherings and outside training are enough to support her apostolate. For her, the first mission of a beata is to serve her local community—not to spend time in personal training.

\subsection{Variations across Fujian}

Beyond the specific case of Nun Shi, the concrete life of beatas varies slightly across Fujian. In the diocese of Mindong, which is also a quite rural area, most consecrated virgins belong to the 'underground' Church (see Figure 1). Even though relations between registered and unregistered communities may evolve after the recent provisional agreement signed between the Holy See and the People's Republic of China, most local Catholics belong to unregistered communities and operate separately but openly (Chan 2012). ${ }^{6}$ In the recent past, the Mindong diocese counted a few hundred beatas. Most of them, especially the oldest ones, live within their family serving their community from their natal home. They have not formally studied, they have not moved out of their parents' house, and they do not wear any specific uniform. Those usually aged nuns spend their time at church helping with daily prayers and rituals as well as with the various prayers surrounding funerals.

Besides these home-based beatas, the Mindong underground communities have now another form of consecrated virgins like Nun Shi lifestyle, the church-based ones. For many of the numerous rural churches of the underground diocese, there are one or two beatas living in the dormitory of the church. They maintain the building and keep it open; they organize daily prayers and schedule rosaries. Although they have not received formal religious training; they have made private vows and enact the permanent presence of an ecclesial care. The parish priest, who is usually in charge of multiple churches, passes by once or twice per week to give sacraments and oversee the community. If these Mindong underground beatas have a situation rather like the one of Nun Shi in Minbei, they travel less and their access to education is limited. Therefore, they depend more on their local community and on the priest's leadership.

In the official part of the Mindong diocese, there are a few women who live and serve within the local communities. In the parish of Fu'an, there is a very active home-based beata who helps with parish affairs and the Catholic elderly home. But this parish also hosts two nuns who belong to a religious congregation elsewhere in China. Because of a well-documented conflict between their congregation and the local bishop who abusively deprived the congregation of its belongings, most of

6 On 22 September 2018, the Holy See and the People's Republic of China announced that they have reached a provisional agreement on the appointment of Catholic bishops in China. Although the real significant of such announcement remains under debate, relations among Chinese Catholics may be impacted. For more information, see https://www.vaticannews.va/ en/vatican-city/news/2018-09/china-holy-see-agreement-appointment-bishops.html accessed on 1 May 2019. 
the nuns left the diocese and two of them are now in Fu'an serving the parish and its elderly home. ${ }^{7}$ In this specific case, the local beata and the two non-local nuns have a rather similar apostolate and enjoy smooth collaboration. Yet, in some places, the co-existence of congregational nuns and beatas can be both a blessing and a challenge. Their difference in autonomy, local connections, religious lifestyle, and resources can generate tensions among them as it did in the past when members of a religious order would for instance try to position themselves as the religious superiors of the beatas (Harrison 2013, p. 134).

\subsection{A Model under Change}

Nun Shi, like most Chinese nuns, is aware that the Fujianese tradition of the beatas is losing ground. Today, most Chinese nuns prefer to belong to a religious congregation and have the support of a community. Yet, when Nun Shi joins workshops and retreats outside of her diocese, she notices how nuns belonging to a congregation constantly complain about community life and daily trivialities. Nun Shi insists that her religious life without its specific clothing, religious community, and formal vows may not be the most encouraged model of the contemporary Church. Still, it brings blessings to local communities. She remembers how the elderly nuns who trained her warned her against the community life that bishops promote. For these earlier generations of beatas, forming a community was the first step toward all sorts of power struggle. Nun Shi knows that her religious life does not really count as religious life in the eyes of most Church leaders. But she still values the model of the elderly nuns she grew up with and she continues to believe that their example can contribute to the Church today. Witnessing the various tensions and dilemmas that the Church is facing, Nun Shi likes to recall that "nuns are not here to rule but to serve".

Still, over the past eight years, there was not a single Fujianese postulant. ${ }^{8}$ Local beatas explain that the one-child-policy leads parents to discourage their daughter from embracing religious life. Also, with the rapid economic development of the country and the multiplication of life opportunities, young Catholic women are not attracted by this way of life. Nun Shi notes that even beatas who received formal training and have a highly visible action do not inspire more vocations. And the diocesan clergy is not really encouraging young women to pursue this type of religious commitment. Therefore, this model of religious life which was grounded in a rural life with large family clans is disappearing. While the majority of Fujianese consecrated virgins are in their forties and fifties, they know that their way of life might vanish soon.

Nevertheless, Chinese Catholic religious life is more than the beatas alone. In the next section, we introduce the main alternative model that shapes religious life in Catholic China. Unfolding its specificities and current challenges, this section also highlights how this other model share continuities and discontinuities with the beatas.

\section{Part II: Community Life and Religious Congregations}

In China like elsewhere, the Catholic Church counts numerous religious congregations ${ }^{9}$ through which Catholic women can take vows, join a religious community, and serve the Church. Yet, Chinese

7 This conflict was highly publicized through national and international media. And similar conflicts have occurred in other dioceses. Thus, these tensions reflect how Chinese nuns are less and less likely to silently accept what is perceived as an abusive and authoritarian policy of the clergy.

8 Estimates of the total number of Catholics in Fujian vary between 200,000 and 400,000.

9 The Catholic Church distinguishes between religious congregations and religious orders. Members of the first take simple vows that can be readily dispensed while members of the last take solemn vows that are rarely relaxed, almost indissoluble. In practice, the two organizations can be extremely similar. In this article, we favor the term congregation to describe the collective organization, but non-monastic way of life made by Chinese nuns. However, it might be loosely understood and does not imply any canonical statement. Some Chinese religious communities are technically a religious order while others are canonically a congregation. 
religious congregations share specific features and challenges that a better understanding of the Church in China requires to acknowledge.

To explore what these congregations have in common, the various forms of religious life they promote, and the difficulties they face, the following section presents the concrete situation of two congregations from northern and eastern China. One is a very large congregation that has a long history and a broad social foundation while the other is a smaller underground community evolving toward a more 'spiritual' religious life. One is primarily based in a wealthy city of seven million inhabitants where there is not a sharp antagonism between official and unofficial Catholics while the other is based in a developing township where most Catholics are not registered. The two congregations together help to appreciate how Chinese Catholic nuns are incessantly adjusting their religious commitment and their role in the Catholic Church in China. If scholars have argued that their unique features are due to governmental opposition and cultural difficulties, and suggest a partial failure in meeting Catholic norms (Leung and Wittberg 2004), this research instead suggests that Chinese nuns value alternative Catholic models of religious life because they empower them in designing a lifestyle suitable to their socio-historical context.

\subsection{A Congregations with Historical Roots: The Little Sisters of Mary}

Many Chinese religious congregations who operate in contemporary China have in some extent been founded during the late nineteenth and early twentieth century when a large number of Western Catholic nuns came to China to support missionary work (Li 2015). Arriving mostly from France, but also from Italy, Germany, or the United States, these missionary nuns were committed to social services such as education of children, orphanage, and medical care (Young 2013). Wearing a distinct uniform indicating their religious status, these foreign nuns were in close collaboration with priests and bishops to support pre-established missions as well as to generate new missionary opportunities. Soon, they invited young Chinese women to join their apostolate and religious commitment. They opened their congregation to the natives or established new ones for them. Thus, this period witnessed a broad Catholic effort to generate numerous indigenous congregations across the Chinese world, such as the Chinese Sisters of the Precious Blood, the Religious of the Sacred Heart of Mary, The Providence Sister Catechists, The Society of Helpers, and so on (Bradshaw 1981; Tiedemann 2010b; Li 2015, p. 121; Chu 2016).

In northern China, the Little Sisters of Mary ${ }^{10}$ traces their history back to the early twentieth century. In a Catholic territory overseen by French Bishops, young Chinese women interested in religious life were invited to become zhennü (beatas). From the early 1910s, they could pronounce their vows in the hands of the bishop and then be sent two by two to serve local communities. They would offer medical care for the sick, as well as education for children. Through countless and flexible involvements, these Chinese beatas were crucial in the development of the local Church and in implementing a holistic Christian care for the broader population. Besides serving within nascent missions and parishes, small groups of them opened asylums for deprived elderly people, others created an orphanage, and some ran a printing house. In a context of continuous civil war fueled by the successive disruptions of the Boxer rebellion, conflicts between warrior lords, and the Japanese invasion, the social welfare induced by these nuns answered to a political and social vacuum where most traditional well-fare institutions were under crisis. With an increasing number of young women joining them, the nuns were officially recognized by the Holy See in the early 1930s as a religious congregation. By the 1940s, the new congregation, the Little Sisters of Mary, counted over one hundred nuns.

10 I here use a pseudonym to respect the privacy of the congregation. Similarly, the article avoids giving some specific dates, names, and number that may jeopardize the anonymity of the congregation. 
However, with the collapse of the Japanese Empire followed by the growing Communist power, these Catholic women decided that young members of their congregation should leave the city and migrate towards the South. At the end of the 1940s, about sixty of them left, and later, a few regathered abroad to recreate a congregation inspired by their experience in northern China. Meanwhile, nuns who have remained in Northern China soon had to leave their pastoral service and return to their family. During the Cultural Revolution (1966-1976), the congregation like every other constituted religious body disappeared and most nuns returned to the life of a home-based beata. Yet, today's nuns insist on how those nuns never stopped praying and serving, even during the Cultural Revolution. The Little Sisters of Mary explained that despite the political context, nuns continued to help and work generously, testifying wherever they were about the evangelical values. By doing so, each of them was maintaining the spirit of their congregation alive-a spirit that does not lay in any single way of life.

With Deng Xiaoping's reforms in 1978-1979, Catholic communities and institutions were gradually able to re-emerge. The Church could reappear in public. In 1989, the local bishop and a few lay people of the place where the Little Sisters $\mathrm{f}$ Mary are now based decided to support the visible recreation of the congregation. One dozen elderly nuns who were living in the region were helped to gather again and restart their public and collective service of the Church. Soon, more than 20 young women joined them to become the new generation of the Little Sisters of Mary. In 1992, a second group of 39 young postulants was accepted while only three elderly nuns were still alive. Three years later, twenty-four of these new postulants pronounced their vows. Today, the congregation counts about 94 nuns, three novices, and no postulant. New vocations are becoming rare, so the size of the congregation might soon decrease. Nonetheless, with their grey robe and white veil, the Little Sisters of Mary are well-known in the region. Their Mother House is constantly visited by all kinds of people from the city and surrounding Catholic communities.

With the constant growth of the congregation, the Little Sister of Mary had to provide training to new members and define their own requirements. ${ }^{11}$ After a few months as a postulant and two years as a novice, a new member can take temporary vows. Between five and seven years later, she can take perpetual vows. During the early stage of this training, each candidate joins pastoral activities with an older nun to embrace the religious mission of the congregation. They also attend specific training programs in accounting, nursing, acupuncture, foot massage, etc. If a nun demonstrates specific abilities, the congregation might ask her to pursue additional training in theology, biblical studies, education, medical care, and so on. Thus, the congregation has mobilized national and international connections, such as Catholic priests and nuns who regularly circulate across China, in order to identify relevant schools and ways to afford tuitions (Leung and Wittberg 2004). Today, sixteen Little Sisters of Mary have been abroad for a Master or a Ph.D. program (France, Italy, Philippines, Taiwan, and the USA). ${ }^{12}$ Those women have brought back their international experience that they continue to share with the rest of their community. In addition to enlarging the professional expertise of the congregation, their experience abroad also allows the nuns to question their local ecclesial culture. For instance, they do not hesitate to describe what some of the nuns did abroad during religious education courses, or what they saw during religious ceremonies, to suggest changes within the parish they serve.

By 2008, the growth of the congregation and the multiple commitments of the Little Sisters have allowed them to gather enough funding from China and abroad to rebuild a modern and large Mother

11 For larger congregations like the Little Sisters of Mary, which are financially independent from their local bishop, Chinese nuns enjoy much autonomy regarding internal governance and training. Whereas other smaller congregations, which financially depend on the local diocese, the bishop often intervenes with the internal governance of the congregation, including the training of the nuns.

12 Two of those highly educated nuns left religious life to get married. Therefore, the current superior of the Little Sisters of Mary is skeptical toward this pursue of higher education that can become a distraction from missionary work and life of prayer. 
House. ${ }^{13}$ Since the Chinese law has allowed them to recover land properties owned before the Cultural Revolution, the nuns erected an impressive and well-maintained building in the center of the city, ten minutes away from the cathedral. At the entrance of this building, a large statue of the Virgin Mary welcomes the visitor, and boards on the walls explain the history of the congregation, the ancient role of the beatas, and the current services of the nuns.

The Mother House not only provides visibility and stability to the congregation; it also offers space for an elderly home ran by the nuns. The home welcomes more than fifty elderly people, Catholics and non-Catholics, accompanied by four nuns and five lay employees. This new apostolate is partially encouraged by the state which is outsourcing expensive social welfare to religious groups. Yet, if the Little Sisters of Mary like many other congregations have thrown themselves into this kind of social service, their involvement remains marked with parsimony and prudence. They do not want to monopolize all their human and financial resources for a single social priority that has been defined by others and that may jeopardize their religious commitment. As several of them told us: "A nun is more than a nurse or a care provider". Nonetheless, some nuns discreetly provide medical care to people with HIV and to nearby homeless people. Although those two populations tend to be stigmatized by the state, local officials turn blind eyes on the support they receive from the nuns. By diversifying their social involvement and taking it out of their Mother House, nuns silently assert their own way to define and help people in need. This multidirectional social engagement illustrates once again what scholars have called the back-and-forth dynamic of cooperation and negotiation between Chinese Christians and state actors (Koesel et al. 2019; Madsen 2019a). Nuns do not simply respond to social needs defined by the state but carefully discern where and how to invest their energy without ignoring stigmatized populations.

In one aisle of the Mother House, there is also a spiritual center where the Little Sisters of Mary organize various retreats and training for lay Catholics. The facilities (dormitories, kitchen, classrooms) of the Mother House are large enough to accommodate a few dozen participants each time. The spiritual center offers courses in Holy Scriptures, human and spiritual development, but also formation about married life and parenting skills, as well as training programs for young Christians, spiritual counselors, and catechists. The nuns also offer a spiritual retreat to groups or individuals. It is worth noticing that participants of those formations and retreats also include people from Protestant Churches, and nuns sometimes invite Protestant ministers to contribute to their training programs. Consequently, their spiritual center is to some extent a site of ecumenical encounter. But the retreats and training it offers also contrast with the traditional Chinese Catholic piety that was primarily based on the daily repetition of prayers and on the regular attendance of mass and confession. Through their retreat center, nuns not only provide a new approach to spiritual life that echoes socio-religious transformations of their wealthy city but also becomes a resource of spiritual expertise. Becoming more than the servants of local parishes, the Little Sisters of Mary explain that through their retreat center, they continue the long-standing commitment to prayer that many home-based beatas have embraced. Today, nuns who live at the Mother House gather in the chapel several times per day for the mass and the Liturgies of the Hours. Visitors and retreatants are welcomed to join. Furthermore, every day and night, nuns take turns to maintain a perpetual adoration of the Holy Communion. This specific form of worship that implies human resources and stability was initiated in 2004 to respond to the demand of a generous benefactor. Fifteen years later, this perpetual adoration is the source of great pride for the entire community.

However, the Little Sisters of Mary consider evangelization as their priority and primary charism. Therefore, 46 nuns do not work and live within the Mother House but within a diocesan parish or in a nearby diocese. Alone or with other nuns, they oversee most parish' activities, teach catechism,

13 While the Little Sisters give us some information about the main origins of their donations, they explicitly requested to remain discreet about it. Officially, their building was made possible through local donations only. 
schedule rosaries, and help the choir. During Chinese New Year, they can take up to fourteen days to visit their family and stay with relatives. Yet, spending most of the year with parishioners, Chinese nuns notice that it is often lay people who introduce non-believers to Christ. Increasingly educated and socially connected, lay people evangelize and indirectly remind the nuns how their specific contribution to the Church is nothing predetermined and self-evident.

To support their various commitments and their needs in adapting their evangelizing skills, the Little Sisters of Mary gather twice a year at the Mother House, once for a one-week spiritual retreat, and once for a one-week training. The content and organization of these meetings are supervised by the Superior and her Council members. Once every four years, the congregation also goes through a General Chapter. All the nuns elect 30 delegates who gather one entire week at the Mother House to discuss the congregation's orientations and to elect a Mother Superior and four council members. The five of them can be re-elected once. Then, they must return to regular religious life for at least one term.

For the Little Sisters of Mary, like for most Chinese congregations contacted during this research, the financial sustainability of the congregation is a matter of concern and recurrent debate. To what extent a nun can devote her time to non-profitable activities that may deploy evangelical values but threaten the financial viability of her congregation and its capacity to give on the long term? Nuns serving in a parish usually receive a stipend around $1000 \mathrm{RMB}$ (US\$145). ${ }^{14}$ But it can vary across the region. The amount is usually given by the parish to the congregation itself. Then, each nun can ask the Mother House for the money she personally needs. Nuns say that they almost always receive the amount for which they ask. The other major income of the congregation is from small shops built on the congregation property along the street and rented out. ${ }^{15}$ Yet, in 2018, the city ordered an urban cleaning and street remodeling that destroyed half of them. Thus, the congregation is always looking for new donations and source of financial autonomy. Some nuns are studying accounting and may follow the example of other congregations where a significant proportion of the community works in accounting for secular corporations. Yet, the Little Sisters of Mary discuss whether this option that opens new economic, professional, and networking opportunities threaten the generous and disinterested dimension of their religious life. Nonetheless, nuns know that while the amount of money circulating within Chinese Catholic networks is constantly and significantly growing, lay people still prefer to donate for the construction of a new and visible building than for the functioning of a religious congregation. Chinese nuns cannot simply rely on the new wealth of lay Catholics, but they must be able to support themselves.

For most congregations, their major financial concern is to afford medical insurance for every single nun. The Little Sisters of Mary explain that it would cost them more than one million US\$ (seven million RMB) to cover arrears and pay annual fees for the whole community. Since all of them are still under 60-year-old, they are mostly healthy and 86 of them do not have any insurance. But they worry about their future. Amid this dilemma, the diocese has recently agreed to cover one-third of their retirement pension. Yet, the congregation would have to cover the rest, and the question of their medical insurance remains unsolved.

In conclusion, the Little Sisters of Mary give an opportunity to see how Chinese religious congregations are a specific kind of Catholic organization. They are diocesan entities which identify with and value the model of missionaries and beatas who generated them. They use their example to define and justify their current position in the Church and their broader society. Most of those diocesan

14 When a congregation is strong enough to negotiate with the diocese, this stipend is comparable to what priests receive. Otherwise, it is lower. Yet, priests are more likely to receive all sorts of donation from parishioners. And this creates a significant income gap between priests and nuns.

15 According to the nuns, their elderly home and other social services do not generate any profit. 
congregations are actually smaller ${ }^{16}$, less educated, and less resourceful than the Little Sisters of Mary. They do not belong to broader religious orders with a national or international network. Although Chinese nuns may cultivate informal relations among congregations and with non-Chinese religious orders, their congregations belong to and depend on their diocese only. It is in this territorial framework imposed by the state and not contested by ecclesial authorities that they have to define their religious identity and sustain their material life. If they are quite autonomous in defining their missions and priorities, the way to support and finance them remains a constant challenge. Therefore, reflecting on a history of change that combines the model of the consecrated virgins and the example of missionary congregations, Chinese nuns cultivate and justify a multidirectional apostolate. They do not simply reproduce what the beatas and early missionaries did but design their own type of social involvement and Church service. Unlike most worldwide Catholic congregations, Chinese congregations do not limit their spiritual and apostolic charism to a single function (parish service, medical care, prayer) but constantly diversify the scope of their action. Similarly, they do not impose a strict community life on each other. Many members live alone or with other nuns in a parish, an apartment, or another related site. Yet, contemporary Chinese nuns tend to gather more and more and live within a single place, a hive of activity, instead of being scattered across vast territories. This type of religious life with its on-going spatial and functional reconfiguration puzzles international observers. However, it allows Chinese nuns to interact with various people without critically depending on a single space, income, and authority.

Finally, it is worth noticing the increasing tensions between nuns and diocese priests. During the Maoist period, they both shared the same banishment and bitter life. However, with the reform period, the public return of Catholic institutions, and the gigantic socio-economic transformation of the country, priests and nuns have increasingly different opportunities and challenges. As we saw with the Little Sisters of Mary, nuns can access some higher education programs, and through community life, they share their professional and abroad experience. By contrast, the training of diocesan priests is usually focused on theological and liturgical issues while being closely monitored by the state. It is harder for them to go abroad. And once ordained, they little benefit from communal learning. Therefore, there is an increasing gap in education between Chinese nuns and diocesan priests. Then, in the parish life, priests have usually to spend a large portion of their time in meetings and training with state officials while nuns monitor daily issues and spend more time with parishioners. In the eyes of many parishioners, the priest remains a figure of authority, almost the incarnation of Jesus Christ, while the nun is supposedly uneducated and the servant of the community. Thus, their pastoral experience and vision tend to diverge, and tensions between priests and nuns multiple. Like elsewhere in the Catholic world, Chinese nuns tend to resist male institutional authority and imposed models of self-sacrifice (Brock 2010). Yet, if a disagreement between a Chinese priest and a nun becomes too important, the priest will usually request from the Superior of the congregation to transfer the sister elsewhere. Thus, Chinese nuns tend to avoid open conflicts and look for other means of action.

\subsection{A Post-Maoist Congregation with Contemplative Efforts: The Sisters of the Immaculate Conception}

To further unfold and nuance our understanding of Chinese religious congregations, it is worth exploring another community that has a shorter history and different priorities. On the Eastern coast of China, the Sisters of the Immaculate Conception are a recent unregistered community which counts 42 nuns and four novices. They mostly operate in a large township located one hour away from the provincial capital. In this developing region, economical opportunities are fewer than in the wealthy city of the Little Sisters of Mary, and divisions between official and unofficial Catholics are sharper.

16 Based on the statistics given in the opening of this paper, the average numbers of nuns within a registered or unregistered congregation is about 37 individuals. The 94 Little Sisters of Mary are therefore far above this average. 
This congregation came to life in the early 1980s. Responding to the interest of several young women, the local underground bishop invited two senior nuns from Shanghai to come and create a new local congregation. Soon, the relationship between the two nuns and the young postulants became complicated and the senior nuns left. Thus, the first postulants who pronounced their vows became also the founders of a new community. With a strong character and an extensive local network, the young nuns attracted new vocations. During the 1990s, regularly up-coming postulants allowed the community to grow slowly but steadily. After a short training within the apartment-convent, new postulants would be paired with a senior nun and go two by two to serve local communities. Together, they provided religious education to children, helped with the organization of the mass and other sacraments, and visited sick people to pray for them. Thus, helping local parishes has been their most consistent service. However, lay people are now better trained and often able to gather more funds and connections than underground nuns can. Therefore, their contribution to local parishes is losing ground and only a fourth of them are still serving them full-time.

In the early 2000s, local Catholics gave the Sisters of the Immaculate Conception a house in a large township and the nuns transformed it into their Mother House. Nearby, they opened a home to welcome individuals with a physical and/or mental disability. A few years later, they also established an old age home. In this coastal region marked by massive emigration, mutating society, and economic competition, traditional family and village structures are not a safety net anymore. Thus, vulnerable people find themselves left behind. Moved by these changing social conditions, the nuns have overcome their lack of training and resources and opened small structures that can provide support to people in need. Over the years, the Sisters of the Immaculate Conception have partially reoriented their time and effort toward these new forms of social service.

In this changing context, the question of their formation has become increasingly central. How to support, orient, and shape the young women who want to join the congregation? What are the guiding principles to train them? Through a few international connections and the support of foreign missionaries, some Sisters of the Immaculate Conception went to study abroad. With the discovery of a foreign culture, the experience of another local Catholic Church, and a firm academic and theological training, the young congregation enlarges its practice and understanding of Christian spirituality and gradually reorients its priorities. Indeed, many of the young nuns demonstrate an interest for a more radical and intense contemplative life through which they can deepen their union with God. Consequently, the congregation has re-enforced the contemplative dimension of its community life by increasing the time spent together to pray, but also the number of spiritual retreats and training offered to lay people. As with the Little Sisters of Mary, the nuns of Eastern China take turns to perform perpetual adoration. Today, the Sisters of the Immaculate Conception seek to reach out to students and young couples in search of a deeper spiritual training. Yet, they maintain their strong connections with the local Church and several nuns continue to serve the surrounding parishes.

Amid these transformations, the current novices shed light on the evolving identity of the Sisters of the Immaculate Conception. Four novices may not seem much but compared to the rapid decline of religious vocations in China, and the total absence of vocation among the Fujianese beatas, the presence of four novices within a rather small congregation demonstrate its attractiveness. The four of them are between 26 and 32-year old. All but one of the four have a university diploma showing that they had a rather deep secular experience outside of Catholic circles before joining religious life. During individual interviews, they also explain that they have kept their Catholic identity secret-or at least private-for years. One even said that she lost it for a few years. And most of them had a romantic but not fulfilling experience before joining the congregation.

Indeed, these young women grew up in a developing China where starvation and the lack of economic opportunities did not exist. Instead, competition among numerous options and rapid social change have defined their coming of age. Today, novices intend to take distance from surrounding hyper-consumerism of their generation. They do not worry about their material needs and the 
sustainability of their lifestyle. For them, “God will provide!". Longing for poverty and dispossession, their motivations are in sharp contrast with the values of mainstream contemporary Chinese society.

When it comes to envisioning religious life, the four novices aspire for a balance between silent and individual adoration, community prayer, and personal growth through community life. What they are longing for is seen as emerging through prayer and community life rather than through parish life and worldly apostolate. Clearly, they differ from senior nuns who trained themselves in relation to local parishes. Even though they often demonstrate real affection and empathy for local Catholics and people in need, the young novices do not consider leaving their community and serving full-time surrounding parishes or Church services. Instead, the novices and their instructors perceive their religious vocation as becoming a praying and benevolent adviser of Catholic communities rooted in a contemplative relationship with God. Therefore, they study psychology to better answer the spiritual needs of those who come to them. But their effort to accommodate contemplative life with apostolate reveals that there is no contemplative community in mainland China today. All Chinese congregations are mainly oriented toward apostolic life (Charbonnier 2014). Like in many places across Asia where monasteries and contemplative communities are rare, Chinese Catholic women looking for contemplative life must negotiate their aspiration within the structures they find. ${ }^{17}$

If the older nuns strongly support the contemplative aspirations of the younger ones, the congregation continues to serve local parishes, elderly people, and disabled people. Like the nuns of northern China, the Sisters of the Immaculate Conception cultivate a multidimensional involvement within their local Church and do not restrict themselves to a single charism, source of income, and identity. Ten of them, two by two, live in a nearby city and serve local parishes. The rest live at the Mother House from where a few sisters supervise the nearby home for disabled people and the old-age home. Interviews suggest that local underground Catholics appreciate their apostolate and respect their consecrated life. But when the bishop and his priests gather large funds for a new project, very little is left for the nuns. Often, new constructions do not even include an apartment for them, as a reminder that their position in the Church is nothing given and granted. And like the Little Sisters of Mary, the Sisters of the Immaculate Conception demonstrate anxiety about their future medical safety and some frustration with the lack of clerical support for their contemplative life.

\section{Conclusions: Navigating Challenges to Translate a Religious Calling}

The study of contemporary Chinese nuns reveals that their religious commitment evolves through various forms of apostolate inspired by distinctive Catholic models of religious life. Although Chinese nuns tend to more often belong to religious congregations, although religious congregations tend to increasingly favor community life, Chinese religious women continue to reflect on the examples of the beatas and missionaries to inspire the ways in which they shape their religious journey.

Thus, the construction of their religious identity does not simply follow the current Catholic framework for religious life (Wynne 1988; Wittberg 1994). In most countries, lay people with a religious calling are invited to permanently join either a contemplative or apostolic congregation that cultivates a specific charism inspired by the life of the founder. Each congregation is supposed to deploy a single and specific way of life through which their distinctive spirituality and their particular apostolate intersect (see Congregation for Institutes of Consecrated Life and Societies of Apostolic Life 2002, especially pp. 20,30). Benedictines dwell in monasteries, praying, studying, and working with their hands while welcoming those in search of a refuge. Members of apostolic congregations devoted themselves to a single social cause -education, medical care, and so on-living in a school, an orphanage or a nursery, working and praying together, while spending most of their time with lay

17 For example, in 1983, among the 96 female religious congregations of the Philippines, only 7 were contemplative (De Achútegui 1984). 
people in need of knowledge or physical care. And most congregations operate within a national or international framework.

In this landscape of highly specialized Catholic religious congregations which work side by side across the world, Chinese nuns and their religious structures appear quite distinct. First, the antique ideal of the beatas continue to exist in China and to inspire those who join religious congregations. Second, Chinese Catholic congregations are all associations of diocesan right. This means they canonically depend on a single bishop, and not on the Pope, while operating alone within a limited territory. Each of these diocesan organizations is neither specialized nor stable but keeps evolving in multiple directions as they partially escape from clerical and state monitoring (Entenmann 1996). Despite all the efforts and frustrations of foreign actors who offer training and retreats to Chinese nuns in order to guide them into a predefined Catholic religious way of life (Leung and Wittberg 2004), Chinese Catholic nuns continue to carefully test the waters and determine how their religious calling can grow in the current reality of China. Thus, they continue a long Chinese Catholic tradition of adaptation (Bays 2012, p. 199). With a certain autonomy from social expectations, political demands, and ecclesial discourses, Chinese nuns patiently deploy all sorts of organizational tools to nourish their religious journey and speak to their society. Indeed, their creative efforts and commitment contrast with an image of Chinese Catholics often portrayed as defensive and relatively insular (Madsen 2019b).

Yet, Chinese nuns continue to wonder about their religious identity as they try to answer questions raised by the universal Church on their specific charism and spirituality. Chinese nuns do not really have a charismatic founder to rely on, a single proto-figure through which they could supposedly tell who they are. ${ }^{18}$ Their congregations and lifestyle result from the encounter of various Church actors (European male and female missionaries, local Catholics) and socio-historical realities (persecutions, economic changes). Also, Chinese nuns know that if they want to financially support themselves and those who come to them, they cannot invest all their resources into a single activity that may disappear anytime. The unpredictable Chinese state-or an authoritarian bishop-could suddenly decide that nuns can no longer work within a kindergarten or an elderly home. Thus, they walk a fine line between opportunities and constraints to define what a Catholic nun is and do in contemporary China. In this journey, it is hard - and tormenting-for them to not fit in the expectations of the universal Church. Church leaders, like many scholars, continue to look at them through what they do not do. And yet, Chinese nuns continue to prove to be resilient, adaptive, and creative.

During our research, a nun playfully quoted the Maoist saying, "Women hold up half of the sky!" to describe the scope of women action within the Chinese society and Church. While Chinese nuns are numerically not half of the Church, they often tend to remain faceless, nameless, and voiceless in the study of Chinese Catholicism (Chu 2016). However, this article has intended to show that they are not countless, neither is what they build together shapeless. Indeed, they bring something specific and unique to the Church in China. Although Chinese nuns may not want to make a name for themselves, nor to speak up publicly, their efforts to shape their religious commitment continue and will continue to inform the reality of the Church in China.

Funding: This research received no external funding.

Conflicts of Interest: The author declares no conflict of interest.

\section{References}

De Achútegui, Pedro S. 1984. The Catholic Church in the Philippines: A Statistical Overview. Philippine Studies 32: 77-106.

Bays, Daniel H. 2012. A New History of Christianity in China. Malden: Wiley-Blackwell.

18 Despite a certain public imaginary reinforced by some Church discourse which tend to homogenize Catholic religious congregations, counter examples are abundant. See for example the Sovereign Order of Malta and the Sisters of Saint Andrew. 
Bradshaw, Sue. 1981. Catholic Sisters in China: An Effort to Raise the Status of Women. Historical Reflections/Réflexions Historiques 8: 201-13.

Brock, Megan P. 2010. Resisting the Catholic Church's Notion of the Nun as Self-Sacrificing Woman. Feminism E Psychology 20: 473-90.

Cai, Xiang-Yu. 2012. Christianity and Gender in South-East China: The Chaozhou Missions (1849-1949). Ph.D. thesis, Leiden University, Leiden, The Netjerlands.

Chambon, Michel. 2018. Materiality and Christianity in Nanping: Making God Present. Edited by Robert P. Weller, Nancy Ammerman, Kimberly Arkin, Robert Hefner and Eugenio Menegon. Boston: ProQuest Dissertations Publishing.

Chan, Shun-Hing. 2012. Changing Church and State Relations in Contemporary China: The Case of Mindong Diocese, Fujian Province. The China Quarterly 212: 982-99. [CrossRef]

Charbonnier, Jean. 2014. Guide to the Catholic Church in China Zhongguo Tian Zhu Jiao Zhi Nan, 8th ed. Singapore: Oxford Graphic Printers.

Chu, Cindy Yik-Yi. 2016. Chinese Sisters of the Precious Blood and the Evolution of the Catholic Church. Hong Kong: Palgrave Macmillan.

Congregation for Institutes of Consecrated Life and Societies of Apostolic Life. 2002. Starting Afresh from Christ: A Renewed Commitment to Consecrated Life in the Third Millennium. Strathfield: St Pauls Publications.

Congregation for Institutes of Consecrated Life and Societies of Apostolic Life. 2018. Ecclesiae Sponsae Imago Instruction of the Ordo Virginum. Strathfield: St Pauls Publications.

Entenmann, Robert E. 1996. Christian Virgins in Eighteenth-Century Sichuan. In Christianity in China, From the Eighteenth Century to the Present. Edited by Daniel H. Bays. Stanford: Stanford University Press, pp. 180-94.

Gernet, Jacques. 1985. China and the Christian Impact: A Conflict of Cultures. Cambridge: Cambridge University Press.

Harrison, Henrietta. 2013. The Missionary's Curse and Other Tales from a Chinese Catholic Village. Berkeley: University of California Press.

Kang, Zhijie. 2013. Jidu de Xin Niang: Zhongguo Tian Zhu Jiao Zhen Nü Yan Jiu. In Zhongguo Tian Zhu Jiao Zhen Nï Yan Jiu. Beijing: China Social Science Press.

Koesel, Karrie J., Yizhi Hu, and Joshua Pine. 2019. Official Protestantism in China. Review of Religion and Chinese Society 6: 71-98. [CrossRef]

Leung, Beatrice, and Patricia Wittberg. 2004. Catholic Religious Orders of Women in China: Adaptation and Power. Journal for the Scientific Study of Religion 43: 67-82. [CrossRef]

Li, Ji. 2015. God's Little Daughters Catholic Women in Nineteenth-Century Manchuria. Seattle: University of Washington Press.

Lian, Xi. 2010. Redeemed by Fire: The Rise of Popular Christianity in Modern China. New Haven: Yale University Press.

Lutz, Jessie Gregory. 2010. Pioneer Chinese Christian Women Gender, Christianity, and Social Mobility. Bethlehem: Lehigh University Press.

Madsen, Richard. 2019a. The Chinese Catholic Church, Between Rome and Beijing and Sinicization from Above and Below. Review of Religion and Chinese Society 6: 5-23. [CrossRef]

Madsen, Richard. 2019b. The Third Globalization of Catholicism in Greater China. In The Secular in South, East, and Southeast Asia. Edited by Peter van der Veer and Kenneth Dean. New York: Palgrave Macmillan.

Mariani, Paul Philip. 2011. Church Militant Bishop Kung and Catholic Resistance in Communist Shanghai. Cambridge: Harvard University Press.

Menegon, Eugenio. 2003. Christian Loyalists, Spanish Friars, and Holy Virgins in Fujian During the Ming-Qing Transition. Monumenta Serica 51: 335-65. [CrossRef]

Menegon, Eugenio. 2009. Ancestors, Virgins, and Friars: Christianity as a Local Religion in Late Imperial China. Cambridge: Harvard University Press.

Simons, Walter. 2001. Cities of Ladies Beguine Communities in the Medieval Low Countries, 1200-1565. Philadelphia: University of Pennsylvania Press.

Tiedemann, R. Gary. 2008. Controlling the Virgins: Female Propagators of the Faith and the Catholic Hierarchy in China. Women's History Review 17: 501-20. [CrossRef] 
Tiedemann, R. Gary. 2010a. A Necessary Evil: The Contribution of Chinese 'Virgins' to the Growth of the Catholic Church in Late Qing China. In Pioneer Chinese Christian Women, Gender, Christianity, and Social Mobility. Edited by Jessie Gregory Lutz. Bethlehem: Lehigh University Press, pp. 87-107.

Tiedemann, R. Gary. 2010b. Handbook of Christianity in China. Volume Two, 1800 to the Present. 1800 to the Present. Leiden: Brill.

Wittberg, Patricia. 1994. The Rise and Decline of Catholic Religious Orders: A Social Movement Perspective. Rise and Fall of Catholic Religious Orders. Albany: State University of New York Press.

Wynne, Edward. 1988. Traditional Catholic Religious Orders: Living in Community. New Brunswick: Transaction Books.

Young, Ernest P. 2013. Ecclesiastical Colony: China's Catholic Church and the French Religious Protectorate. New York: Oxford University Press.

(C) 2019 by the author. Licensee MDPI, Basel, Switzerland. This article is an open access article distributed under the terms and conditions of the Creative Commons Attribution (CC BY) license (http://creativecommons.org/licenses/by/4.0/). 



\title{
Article \\ Online and Offline Religion in China: A Protestant WeChat "Alter-Public" through the Bible Handcopying Movement
}

\author{
Carsten Vala ${ }^{1, *}$ and Jianbo Huang ${ }^{2}$ \\ 1 Department of Political Science, Loyola University Maryland, Baltimore, MD 21210, USA \\ 2 Institute of Anthropology, East China Normal University, Shanghai 200241, China; jbhuang@soci.ecnu.edu.cn \\ * Correspondence: cvala@loyola.edu
}

Received: 7 August 2019; Accepted: 25 September 2019; Published: 29 September 2019

\begin{abstract}
Studies of digital religion frequently take democratic regime settings and developed economic contexts for granted, leaving regime and economic development levels as background factors (Campbell 2013). However, in China, the role of the authoritarian state, restrictions on religion, and rapid social change mean that online and offline religious practices will develop in distinct ways. This article analyzes the 2019 Bible handcopying movement promoted through China's most popular social media WeChat as a way to commemorate the hundredth anniversary of the publication of China's most widely used translation of the Bible. Drawing on interviews by and communication with the movement's founder, the co-authors participated in and collected postings from a 500-member WeChat group from March to August 2019. We argue that while offline handcopying is an innovation in religious practice due to Chinese cultural and historical traditions, the online group constitutes a micro-scale "alter-public" (Chen 2015; Warner 2002), a site for religious discussion, prayer, and devotion that strengthens an "alternative" Protestant identity alongside that of Chinese citizen of the People's Republic of China.
\end{abstract}

Keywords: digital religion; WeChat; China; Protestant Christianity; "public"; "counterpublic"; "alter-public"; authoritarian state

\section{Introduction}

Scholars of religion and media have recently embraced the term "digital religion" to describe how digital media are reconstituting religion in novel ways to create technological and cultural spaces that meld offline and online religious realms (Campbell 2013, pp. 3-4). Many studies take for granted a democratic context and an advanced industrial country setting such that it is also taken for granted that digital religion evolves largely in response to societal forces. In these settings, political authorities take laissez faire approaches to managing religious groups, and economic development and social change proceed at an incremental pace, and so the political context and pace of societal change are left as implicit factors. Unsurprisingly, therefore, fewer studies have examined digital religion in authoritarian contexts where the pressures from state actors can shape the interaction of electronic media and religious practices (but see Travagnin 2016). In China, the role of the authoritarian state, its restriction on religious practices, and rapid social change, including the population's uptake of social media, suggest that online and offline religious practices may develop distinctly from those in liberal democratic countries with developed economies.

In this paper, we analyze the case of a Chinese Protestant house church leader who used China's most popular social media app to launch and sustain an off-line movement to handwrite the Bible, as a 
way to commemorate the hundredth anniversary of the publication of the Chinese Bible. ${ }^{1}$ Although he launched and sustained the handcopying movement entirely through digital media, the church leader was actually seeking to draw the Chinese-speaking public in China and abroad to undertake the analogue work of handcopying biblical scriptures. In the process of encouraging offline study of God's words in the Bible, the leader also created a new digital forum for religious activities. This in-between "third space" (Hoover and Echchaibi 2012) we argue, is a Protestant "public" (Warner 2002), where strangers can interact in a focused, evangelistic, and pietistic space that has characteristics that mimic those of "house" churches. This WeChat public is also an example of digital religion, where pre-existing offline religious communities are reinforced and develop new links to each other through the online WeChat group.

Frequently, studies of digital religion underscore the two distinct effects that online religious practices can have on offline religious communities, either reinforcing traditional groups or, alternatively, challenging their boundaries (Campbell 2013, pp. 4-5). By contrast, in China, scholars have typically found that pre-existing religious communities have transferred religious content to online platforms in examples of "religion online" (Xu and Campbell 2018, p. 264), but less frequently have they found religious innovation by individuals and groups who alter what is understood as religion through "many-to-many interactions" or cases of "online religion" (Helland 2000). The most likely place to find such innovation is on China's social media, such as WeChat, the site of the most diverse religious content and a vehicle for such "many-to-many" networks (Xu and Campbell 2018).

English-language scholarship on WeChat and its impact on society or religion in China is a small but rapidly growing field (e.g., Harris 2018; Huang 2016; McDonald 2016; Tarocco 2019; Travagnin 2016). Several recent articles have analyzed WeChat's role in transforming spaces for China's religions. For Uighur Muslims in China's repressive Northwest, WeChat enabled Muslim sound recordings to be shared such that a nascent Islamic "counterpublic" developed (Harris and Isa 2018, p. 11); for Shanghai's unregistered Tzu Chi Buddhists, WeChat served as a sacred "third space" for communication, bonding, and linking to the organization's global practices (Huang 2016, p. 112); and in a southeastern coastal temple, Han Buddhist disciples formed an "intimate public" (Berlant 2008, p. viii) whose heavy use of WeChat in "pious self-making" opened them to a deeper experience of their monk's charisma in daily life (Tarocco 2019).

In the Muslim case, WeChat sheltered a space from the monitoring state for religious participation that would otherwise have been impossible and fostered an Islamic identity in opposition to the offline lived reality. In the Buddhist cases, WeChat strengthened or reinforced the offline religious communities or practices. In the Protestant case under examination here, the online community was simply a byproduct of an effort to increase offline devotion, even though it in turn became its own site for prayers, worship, and religious activities. In comparison, however, the Protestant case in this study is less oppositional than the Muslim case and more an alternative to the official definitions of religious identity.

In short, the Protestant "public" that develops on WeChat is more an "alter-public" than a "counterpublic" (Fraser 1990), because although Protestants (like Uighur Muslims) share a subordinate status in China, their WeChat group is not cultivating an oppositional self-understanding. Rather, its activity of Bible handcopying and the movement's explicit goals suggest a less direct engagement with political conflict or political resistance. Thus, it promotes a different Protestant identity without casting itself and its antagonist the state in explicitly dichotomous terms. We construct the term "alter-public" by drawing from Michael Warner's discussion of publics and combining it with Chen (2015) work on literary censorship as capable of creative production. Chen coins the term "alter-production" (Chen 2015, p. 19) to capture how literary creativity under censorship may include

1 The Chinese Union Version (CUV) Bible is viewed as a symbol of the unity of Chinese Protestants, because it was translated through the unified efforts of foreign missionaries of different denominations and their Chinese language assistants (Zetzsche 1999). 
content that is counter- or resistant to the party-state but it may also include content that is not. Alter-production underscores the idea that censorship can play a productive, not just a negative, role in literary development. We add the "alter-" prefix to "public" to capture how censorship (or fear of censorship) and state intervention encourages the WeChat group organizers to cultivate a public that is not explicitly counter to the ruling authorities and its official agenda. In real terms, this alter- rather than oppositional character of the Protestant WeChat public meant that members rarely referred to offline religious persecution, and when they did, such mentions were met with silence by the WeChat group organizers.

In the rest of the article, we first give greater detail on the key handcopying leader, Wang Wenfeng, and explain our position in the WeChat group as we collected data. Next, we explain the offline elements of the handcopying movement, highlighting first how writing out scriptures has special significance in Chinese cultural traditions. We argue that its promotion as a religious practice is an innovation and describe how its founder aimed for it to counter the ill effects of rapid modernization on biblical attachment. Next, we provide political and historical context for understanding Chinese Protestant Christianity in the People's Republic of China, including why 2019 marks a particularly troubling time for China's Protestants. In the last half of the paper, we suggest how restrictions on traditional mass media prompt Chinese Protestants to take to social media and then we analyze the WeChat group for the Bible handcopying movement as an "alter-public." We close by discussing the merits of studying a small-scale public, its distinctions from the rational public sphere, and implications for the stability of the Chinese regime.

\section{Methods and Data Collection}

To study the workings of the Bible handcopying movement in the WeChat group, we joined the WeChat group as passive observers. We decided not to interact in the group to avoid influencing its development and thus to limit our role to observation of members' behavior and participation. To that end, we collected dozens of its postings over a period of six months, from March 2019 through August 2019. In addition, one co-author conducted several phone interviews and exchanged multiple WeChat chat messages with the organizer Wang Wenfeng. We also drew on an interview with Wang that was published on a Chinese QQ site (Weixin QQ 2019). Given the potential sensitivity of the topic, we asked Wang whether we might name him in this article and he assented. We have left all other members of the group anonymous.

Wang Wenfeng is a fourth generation Christian from Wenzhou, the city in China with the highest proportion of Protestant Christians (Cao 2011). ${ }^{2}$ After partially completing a high school education, he began fulltime preaching work. He moved to Beijing for further education and to do ministry work with college students. There, he met his future wife, a Korean Presbyterian missionary, and together they started an unregistered theological training school that ran for a few years. He earned his PhD in Malaysia before returning to live in Beijing. Party-state authorities put him under close watch from 2013 after he organized a group of Chinese intellectuals from across the ideological spectrum with Chinese Christians in Oxford, England to produce the Oxford Consensus, a public call for pluralism and liberalism in China (New York Times 2013). Prior to the handcopying movement, he set out to collect all Christian-related publications in Chinese to form the Jing Zang (lit. Nestorian Collection, referring to the first churches in China), a giant collection of all Christian writings in Chinese. Although this project stopped after police interrogated Wang and other organizers, it revealed to Wang the importance of words, writing and word-related ministry, which served as preparation for the handcopying movement. Although he lives in Beijing now, Wang's family and extended networks trace back to Wenzhou, which explains why the most active WeChat members are also linked to Wenzhou networks. Theologically, he is a Calvinist, which influences him to be very concerned with issues in the wider public.

2 This paragraph draws upon one author's personal knowledge of Wang's background. 


\section{Writing in Cultural Perspective: Bible Handcopying as Religious Innovation and Antidote to Modernity}

Through this movement, Protestant house church leader Wang Wenfeng has created a religious innovation by promoting the collective handcopying of the Bible. ${ }^{3}$ This act of writing and, in particular, of writing out the biblical scriptures carries deep cultural resonance in Chinese tradition. Historically, the written word, rather than speech, was the favored communication mode for imperial power (Jenner 1992, p. 184 cited on Yen 2005, p. 15). When the dynasties came to an end, the civil service exam system was abolished and Western schooling systems were introduced (Chau 2012). These two related events undermined the central role of Chinese as a written language and threatened local elites who had built careers on their mastery of it. In response, local literati, seeking to regain a sense of purpose and identity, turned to "cherishing written characters" as a devotional practice (Chau 2012). Anxious about the encroachment of Western power, they began to view in the written language a fundamental element of Chinese civilization (Chau 2012, p. 143). Written Chinese started to be understood as integral to being Chinese.

Furthermore, within spiritual realms, writing does more than just convey religious ideas or beliefs; it can become an object of veneration itself (Yen 2005, pp. 15-16). Protestant house church groups have long prized scriptures as holy, and the Bible as a touchstone for arguments about whether official churches are compromised or "false" (Vala 2018, chp. 4); individual Protestants speak of how God's words have nourished them in times of imprisonment or other tribulation. Thus, not surprisingly, the Protestant Chinese Union Version (CUV) Bible, the most widely used translation, has become a sacred object in its own right, as the key text that has sustained Chinese Protestant Christianity through more than half a century of political pressure and societal change.

That writing out the Protestant scriptures has taken on the characteristics of a new religious practice becomes even more clear from the intention and impact of the handcopying initiative. The goal of this movement, according to its founder, is to ensure public attention and Protestant church fidelity to the biblical scriptures. In a 2019 interview, house church leader Wang expressed a hope that despite the threat of new ways of thinking ("multiculturalism") in Chinese society, that the "church community will always adhere to Bible-centered beliefs" and that people in society would be directed to pay attention to the Bible (Weixin QQ 2019). Within the online (WeChat) group he founded for the movement, Wang frequently responded to members' comments about finishing a portion of the Bible with some variation of, "May God's words remain in everyone's hearts!" or "May everyone thirst for God's words."

At the broadest level, Wang is critiquing the "hollowing out [of] civilized society (wenming shehui)," by underlining the "anti-religious ... Enlightenment ideology" underpinning the Party-state's pursuit of a modern, wealthy society (Weixin $Q Q$ 2019). He argues that the foundation of modern civilization lies in the Bible, and therefore castigates the anti-religious spirit as weakening the entire "foundation" of modern civilization in China. At the same time, he warns about the impact of multiculturalism, and intends that the movement should return society's civilizational roots (and church faith) to biblical foundations.

Part of this foundation was the efforts by foreign missionaries to bring Western modernity's institutions and values to China. While the Party-state has concentrated on the military dimension of Western powers' impact on China, foreign missionaries had a far wider effect, including cultural, societal-institutional, and ideational dimensions. Thus, alongside the CCP's emphasis on foreign imperialism and gunboat diplomacy that protected missionaries, foreign missionaries also established printing presses, girls schools, women's colleges, universities, hospitals and clinics (Bays 2011; Lee 2014;

3 Handcopying the Bible is not unprecedented in contemporary mainland China. Catholic church members started a few years ago and several official Protestant churches in 2019 as well have embarked on handcopying, although without the organized, widespread effort examined here. 
Lutz 1988). The translation of the Chinese Union Version in 1919 was also the first book translated into a new and vernacular form of written Chinese, as against the classical Chinese of imperial China (Tang 2019). The CUV promoted reading among Chinese commoners and influenced early 20th century mass political movements. ${ }^{4}$ Thus in a time when the CCP is once again targeting Christianity for cultural attacks in its efforts to make Christianity more Chinese, the Bible copying movement may be read as a defensive movement to offer an alternative identity, with a narrative about the positive contributions of foreign missionaries to modern Chinese history.

However, the handcopying movement is more than an effort to counter state propaganda; it is also aiming to counter societal trends. China's economic growth rates have been so high that newfound wealth has sparked rapid social change and upended longstanding societal norms. Protestants frequently complain about how the love of money has made so many people untrustworthy, as they often break promises, and how widespread sexual improprieties have become (Vala 2018). In addition, individualism has undermined collective norms (Yan 2010, p. 2), while electronic media and the Internet have drawn away people's attention and energy from traditional institutions like the family and their speed has made modern life a frenzied experience. By contrast, handwriting requires sustained attention, patient focus, and slow deliberation. Hence, against the busyness of modern life, Wang hopes the movement will encourage people to slow down and focus on the Bible.

While the primary goals are thus to draw China's Protestants and non-believers into engagement with the biblical scriptures, Wang also aimed for handcopiers to see themselves as part of a historic community—both ancient and modern—of Bible writers. For more than a millennium, he pointed out, handcopying was the principal way to spread the Bible (Weixin $Q Q$ 2019). By participating in re-writing the scriptures, handcopiers joined "Old Testament Jewish scribes, saints of the ages, and faithful servants of God in the Cultural Revolution." Handcopiers therefore participate in several "imagined communities" (Anderson 1983): in the earliest days, as the original scribes who first put into written words the oral histories that became the scriptures; after Jesus' appearance, as members of the historic Christian community from the first century onwards; and, nearer to home and more recently, as writing alongside Chinese who furtively copied scriptures during the Cultural Revolution fifty years ago, when Chinese Communist Party Chairman Mao Zedong had banned public religion and Bibles were difficult to find.

In this way, the Bible handcopying movement becomes a vehicle for 21st century Chinese Christians to see themselves through a new identity, not as the "persecuted church" of the West's imagination nor only as "patriotic citizens" who are loyal fellow-travelers to the Communist Party in the People's Republic of China (Entwistle 2016; Vala 2013). Instead, they are heirs of a longstanding religious and historic tradition that was central to recording and preserving the scriptures. Preserving the scriptures meant ensuring their survival during the Cultural Revolution period but in today's China it takes on the meaning of protection from corruption. As we explain below, the Chinese Communist Party has added new impetus to a recent effort to "sinicize" (make more Chinese) Christianity, in which one component is to reinterpret traditional doctrines and possibly rewrite scriptures themselves.

\section{Protestants in Xi Jinping's China: Under Offline and Online Pressure, but Active on Social Media}

The Chinese Communist Party's (CCP) aim to "sinicize" Christianity in 21st century China culminates a fraught relationship between the CCP, Christianity, and foreign Christians. "Making Christianity Chinese," the translation of this agenda, stems from the regime's casting Christianity since 1949 as a competitor to its ideology, a "foreign religion," and a tool of foreign imperialism to sway Chinese loyalties away from CCP rule. This agenda took institutional shape in the 1950s when the

4 Chen Duxiu, a member of the New Culture Movement who became a founder of the Chinese Communist Party, wrote approvingly of Jesus's universal love and self-sacrifice as found in the Chinese Union Version Bible (Chen 2008, pp. 27-28). 
CCP established an umbrella organization for Protestants, the Three Self Patriotic Movement (TSPM) association, which captured Chinese Christian support through a Korean War mass campaign that demonized foreign Christianity and presented TSPM support as a demonstration of regime loyalty. Today, all churches must be affiliated with the TSPM to receive state sanction as official churches. Unregistered (or "house") congregations are distinguished by their intentional refusal to or neglect of (or of authorities' rejection of church efforts to) joining the TSPM, for a variety of reasons (Dunch 2001; Hunter and Chan 1993).

The foreign ties and institutional autonomy of unregistered congregations have periodically been a target of Party-state suspicion and scrutiny, and even a justification for state intervention, especially as unregistered groups have drawn on foreign aid (training, literature, and so forth) to develop their organizational work (Vala 2018, chp. 6). Nevertheless, within the TSPM, official Protestant church perspectives on foreign Christians' historical involvement in China and its churches has softened somewhat recently by acknowledging the positive contributions they made to modern China and contemporary Protestant Christianity (Kuo 2011). And yet, across China divisions still persist between the official churches and the unregistered churches, although the nature and existence of the differences and whether they bar leadership-level or congregational-level cooperation is a matter of enormous local variation (Cao 2011; Kang 2016).

Set in the context of these historical divisions between official and unregistered streams of Christianity, the years leading up to 2019 have been a particularly tense time for China's Protestants. Three offline and online events stand out as exemplifying the worsening context for Chinese Protestant worship. First, shortly after Xi Jinping assumed the top political leadership positions in 2012, a crackdown on Christianity was launched in one province that then has spread to the whole country. In 2013-2015, political leaders in Zhejiang Province had ordered dozens of crosses removed from official churches and destroyed large, unregistered churches (Hao and Liu 2018). ${ }^{5}$ It turned out to be a pilot test for a wider attack on Christianity, as state forces across the country have jailed prominent house church leaders and banned their unregistered congregations, and even gone so far as to confiscate the buildings of official churches of the TSPM (Lu 2019). ${ }^{6}$ This offline persecution made visible the regime's animus toward Christianity.

Along with this coercion, the Party-state revised its legal framework to further restrict religious activities and to limit online religious content. This 2018 national regulation on religious affairs bans overseas religious training and fundraising, emphasizes that Protestant activities outside TSPM locations are illegal, and also newly recognizes the importance of online religious activities, as it includes stipulations regarding approval for online religious content (Zhang 2017).

Thus, adding to the offline cross campaign and its corollaries and the increased online regulations, the aim of sinicization of Protestant Christianity compounds existing anxieties of Protestants. Unregistered church leaders fear that sinicization entails undermining historic Protestant doctrines (Vala 2018). Indeed, the TSPM has officially endorsed plans that call for churches to teach socialist values within Christian circles (CCCTSPM.org 2018). The result of all these events is an unprecedented level of pressure on Protestants, greater than any other period of the last quarter century.

In the public realm of media, CCP control of the state media and commercial media outlets leaves few venues for discussion or practice of Protestant Christianity. Major newspapers rarely report news about religion at all, apart from state policy pronouncements or brief mentions of religious leaders' ritualized courtesy calls with Party-state officials. Within Protestant institutions like the TSPM churches, the national TSPM magazine Tianfeng and Ganlu are two of the few print media publications that are openly published and widely distributed in China. And, so, it is perhaps unsurprising that Protestants

\footnotetext{
The anti-cross campaign provoked widespread resistance from Catholics and Protestants (Cao 2017; Vala 2019; Yang 2018). Catholics and Protestants are not the only religious groups to be under severe pressure. Buddhist and Daoist temples and statuary have also been destroyed, while Uighur Muslims have been detained in unprecedented numbers and sent to camps throughout northwestern China's Xinjiang Province.
} 
have taken eagerly to China's social media apps. First, on microblogging sites such as Sina's Weibo, Chinese Protestants formed a sphere of relatively free discussion on a range of religiously related issues, such as what "patriotism" (aiguozhuyi) means for Protestants. On these accounts, even though only a few microbloggers actively engaged with a few interlocutors, each public account boasted millions of followers so that the microbloggers' one-to-many interactions directly reached huge audiences (Vala and Huang 2016). Until the Party-state's crackdown on Sina's microblogs in 2013-2014, Weibo had cultivated a cyberspace for rather vigorous debate.

Since then, WeChat (weixin) has become the most popular social media app in China, tallying more than 1 billion daily active users (Lee 2019) in 2018 as compared to Sina Weibo's 430 million active users (Ren 2018). Along with the change, the format of interaction has shifted, as Weibo's direct, "megaphone" mode enabling one person to directly message many people has been replaced by WeChat's smaller-scale venues, in which an individual can directly engage with no more than 500 others at a time (Harwit 2017, p. 317). ${ }^{7}$ The shutdown of the most popular Weibo personalities indicates that social media, like state and commercial mass media, have also drawn Party-state scrutiny and monitoring.

\section{The Bible Handcopying Movement WeChat Group as a "Public": Origins, Discourse, Tone}

In the context of this widespread regime pressure, Protestant leaders in Wenzhou, the city with China's highest proportion of Christians in the entire country (Cao 2011), discussed promoting handcopying to commemorate the 1919 publication of the Chinese Union Version of the Bible. To be sure, this is not the only Chinese translation of the Bible, nor was it the earliest or the most recent version (Zetzsche 1999, pp. 47-48); however, the Union Version remains the most widely used Chinese version in mainland China and the Chinese-speaking world (Scottish Bible Society 2019). The commemoration memorializes the cooperation of foreign missionaries from multiple denominations with Chinese assistants who labored for more than 25 years (Zetzsche 1999). However, while other Protestants worried that publicizing the effort would provoke a crackdown from authorities, Wang Wenfeng was willing to risk harassment to engage a wide range of lay believers in the anniversary event (he had been questioned by security forces many times before ${ }^{8}$ (Interview, May 2019)).

On January 18, Wang launched the Bible handcopying project on WeChat by addressing "all friends" that "the Chinese Protestant world" wishes to honor this "important historical moment" by launching a "public interest activity" of copying the Bible (Weixin $Q Q$ 2019). The plan was for the "Chinese public (guangda huaren)" Bible, and thus he "invite[d] Christians and friends in society at home and overseas" to sign up, complete handcopying of a book of the Bible within a set period of time, and mail the pages to Wang. In return, he would send a certificate of completion. Finally, Wang set up a large-scale WeChat group. The appeal beyond a narrow population of fellow believers to a larger public composed of non-Christians ("friends") in China and abroad is significant in his seeking to create a larger public.

In addressing Christians and friends, Wang conjured up a public for the movement, fulfilling two features of Michael Warner's "publics," that they be self-organized and that they bring together strangers as an audience (Warner 2002, pp. 51-52). Clearly, the movement was not state-initiated; more

7 Circumvention of the 500-person limit is possible through "daisy chain" messaging in which a member of one group re-posts messages in other groups of which she is a member (Harwit 2017, p. 318).

8 State security especially questioned Wang after he organized a 2013 international conference that culminated in a joint statement calling for pluralism and liberalism by Chinese Christians, liberals, New Leftists, and New Confucians called the "Oxford Consensus" (Johnson 2013).

9 Wang used the term huaren to connote all "Chinese peoples" around the world rather than zhongguo ren which suggests "Chinese people living inside the country." 
importantly, the online and offline realms comprised strangers. ${ }^{10}$ Indeed, Wang and others added several people to the WeChat group in the course of the six months we observed it, and none of these new arrivals was already linked to existing WeChat group members. In total, more than half of the nearly 500 members were strangers to Wang himself (personal communication with one author, July 2019). The members in the WeChat group online were also connected to congregations and other groups in the offline Bible handcopying movement, indicating that the offline aspect of handcopying encompassed a far greater range of strangers. Within China these Bible handcopiers lived across the country: in major cities such as Beijing and Shanghai; in the southern coastal areas of Guangdong and Zhejiang; the southwest (Yunnan and Guangxi); the central plains of Anhui and Henan; west to Shaanxi and to northern areas of Hubei, Inner Mongolia, and the northeastern areas. Theologically, many participants were strongly evangelical, but some would claim adherence to Calvinism while others are rooted in the Pietist tradition. At the international level, participants joined in from the United States, Russia, Singapore, South Korea, and elsewhere.

More than the membership composition of the WeChat group or its offline extent, a particular type of discourse tied these strangers together as a public. It was strongly reminiscent of discourse found in mainland Chinese house churches. In other words, the WeChat group did not endorse or permit just any kind of discourse; rather, the WeChat public was marked by a focused, encouraging, evangelistic, and pietistic discourse, whose tone was set by Wang as the founder, maintained by others who helped run the WeChat group, and then embraced by various group members themselves.

The clear focus of the group was Bible handcopying and subjects related to Bible study and research. Indeed, the most frequent posts comprised lists of the Bible books which had already been claimed for handcopying. These daily posts contained separate lists of handcopying projects for Sunday school classes, children (ages up to 14 years old), families, individuals, churches, organizations (like drug rehab centers or nursing homes), or pastors doing the handcopying. We called the person doing this posting the "administrator" of the group, as she kept track of these lists and kept discipline in the group (more on this below).

Yet far from being a mere bureaucrat, the administrator reinforced the WeChat group tone set by Wang, a tone that was warm, gentle, and encouraging. For example, after publishing the updated lists in the large WeChat group, the administrator regularly added four "stickers" (animated gifs) with short Christian text messages. (See Figure 1) The first was a picture of an open Bible with automatically turning pages that had the words, "God's words are seeking God; the life and bread of all people"; the second was a cute sheep with blinking eyes sitting at a table with an open book and the words, "pondering [the Bible] day and night;" the third was a black-and-white picture of the side of a Caucasian child's head with eyes closed and clasped hands with the words, "thankful ... "; and the fourth was a cartoon of a female angel in a red and blue dress with orange hair and clasped hands, with the words, "Emmanuel" pulsing next to her.

When responding to a variety of posts, the other members of the WeChat group followed in the same warm tone with most posts consisting of short, approving, Christian-themed stickers. These included a cartoon full-body Jesus with each hand in a thumbs-up position and three characters down the side ("like, like, like"), rotating Chinese characters ("Hallelujah, praise be to God"), pages that turned from one ("thanks to God") to the other ("praise God") in endless cycle, an open Bible with words at the top ("Oh Lord! Your word is a lamp unto my feet, a light unto my path!") and at the bottom (in larger letters, "Bread of Life"), or a bouquet of roses with a shower of pink rosebuds falling down the picture ("Jesus loves everyone" under the bouquet). Even non-Christian imagery also tended to be exhortatory or encouraging. One sticker included a white blob figure slapping together red and blue sticks like those found at sporting events, another was a thumbs up hand with

10 Warner points out that terms such as "the public" or "the nation" would make little sense if only familiars comprised them, for then one would say, "family and friends." Hence, publics must be composed of strangers, who nonetheless may become acquainted in the course of being addressed (Warner 2002, p. 56). 
the words "too awesome (taibangle)," and a third was a simple emoji of a cup of coffee. Through this variety of stickers and encouraging phrases, the WeChat group generated a feeling of belonging among strangers, a shared "sense of community" (McMillan and Chavis 1986, p. 9) that marks publics (Warner 2002, p. 70).

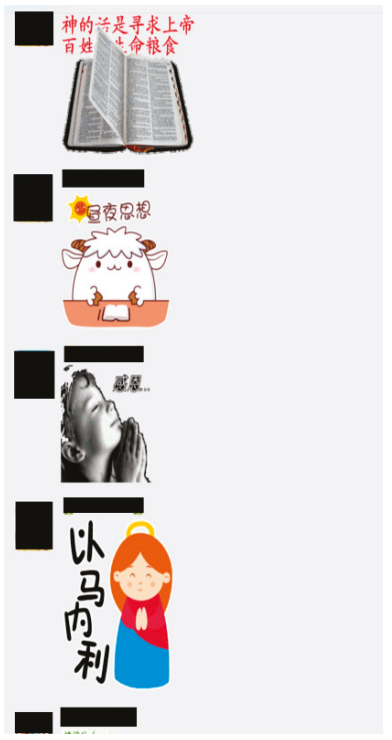

(a)

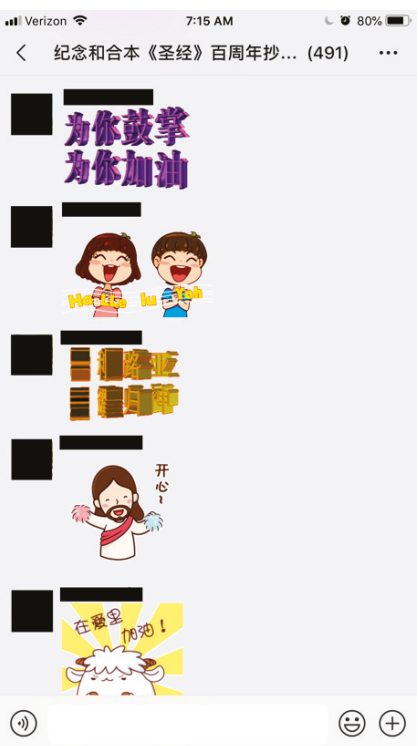

(b)

Figure 1. Typical postings in the Protestant WeChat group (a) a picture of an open Bible with automatically turning pages that had the words, "God's words are seeking God; the life and bread of all people"; the second was a cute sheep with blinking eyes sitting at a table with an open book and the words, "pondering [the Bible] day and night;" the third was a black-and-white picture of the side of a Caucasian child's head with eyes closed and clasped hands with the words, "thankful ... "; and the fourth was a cartoon of a female angel in a red and blue dress with orange hair and clasped hands, with the words, "Emmanuel" pulsing next to her. (b) "Clapping for you, spurring you on"; two children singing, "Hallelujah"; revolving golden letters saying, "Hallelujah, Glory to God"; Jesus as a cheerleader with pom-poms, "Happy"; sheep with sun rays, "Encouraging you in love."

\subsection{Reassuring Participants of the Spiritual Rewards from Bible Handcopying: Two Testimonials}

More than just mere electronic stimulation, the group's encouragement to each other to copy the Bible took more substantial forms as well and suggested lifelong benefits to the activity. This was illustrated by links that members posted to two stories of people who had copied the Bible. In the first case, a group member posted a link to a story about the member's father who was a poor, rural carpenter. Unable to afford a Bible, he returned again and again to the home of someone who owned a Bible to copy scriptures for his own reading. Over five years, he had finally copied the entire New Testament. Because he had accepted faith in Christ quickly and immediately refused to carry out traditional funerary rituals in his home area, his fellow villagers had initially taken offense at his life change. However, according to the storyteller, his strong work ethic and honesty eventually gained him their respect. Thus, handcopying for this new convert had been a necessity to have access to reading the scriptures, but it also implied that those handcopied sheets helped deepen his convictions to reject non-Christian religious practices and to act in upright ways.

Shortly after this link was posted, another WeChat group member linked to a photo essay of a middle aged, homeless man in southern China who loved to read and handcopy "a classic." Born in 
the poor inland province of Henan, the man's parents both died when he was young, and so he roamed the country until he settled under a bridge in Fujian Province more than ten years earlier. The original photo essay leaves out a few details: it only states that he has enjoyed "reading classics" the past two years, that he has spent much time copying them, and that he enjoys going to a local "meeting place" (huisuo) where he has met young people. However, the group member who linked to the photo essay claimed to know a key detail, "the classic is of course the Bible," suggesting that the meeting place was a local church, too.

Reactions by group members were swift and full of praise. The administrator followed with typically encouraging remarks such as, "Peace! So thankful! God bless! Hallelujah! Emanuel!" and a Bible verse about contentment in every situation by relying on God (Phil. 4: 12-13).

Another group member then posted photos of a shelter that he built for copying the Bible, stressing that his material conditions were "much better" than that of the homeless man, adding, "I am really grateful." The administrator responded with, "Grateful! At all times and in all places! God bless you! Go for it!" while another group member added a sticker depicting three cartoon angels singing and playing instruments with "Hallelujah" printed in large letters and confetti twinkling all around.

These stories, together with the speed with which other group members and the administrator responded to and validated them, function as testimonials that suggest the impact that Bible handcopying and thus Christian faith can have on individuals. In one story, Bible handcopying bolstered the integrity of a lone Christian isolated from non-Christians around him by his rejection of their community rituals, while in the other story it gave solace to someone who appeared to have lost all relational ties and earthly comforts. Bible handcopying in these instances helped reassure the Protestant Bible handcopying public that their efforts were not merely time-consuming and laborious but would reap greater rewards than accumulating sheafs of copied words.

\subsection{Beyond Protestants and into the Offline World: Training Scholars, Sharing Personal Stories}

Although this Protestant public is directed towards Bible handcopying, it is focused on more than just completing a task and satisfying its own spiritual needs. In two examples, the WeChat group illustrated the evangelistic dimension of the discourse as it reached out in two senses: first, from the online to offline worlds, and second, beyond Protestants to influence others. The first example illustrates one-on-one personal evangelism, which is an abiding feature of China's conservative Protestant house church Christianity (Bays 2003, p. 502; Koesel 2013, pp. 580-82; Vala and O'Brien 2007). A middle-aged member explained, in a longer post, how he had told a former middle school classmate about the handcopying project. She soon began to copy a Bible book with her first-grade daughter. "This is the Lord's special grace and mercy," relayed the member to the larger group, "allowing this primary school teacher and her daughter to learn of the gospel through this way." Neither the teacher nor her daughter had ever heard the Christian message before, claimed the group member. The group member also sent her a new Bible, asking permission to inscribe its frontispiece, which he did with an evangelical verse about salvation (1 Tim. 1: 15-16). To the large group, the member asked for prayers that "the Lord would elect them to become his daughters," and for himself to finish copying the entire Bible in the next eight months. Rather than merely explain all this through words, the member sent screenshots of his entire WeChat conversation and a photo of his inscription (apparently without the teacher's knowledge).

The second example illustrates an institution-building approach to reaching society with the Christian message. The organizer Wang introduced a documentary film on an effort to build up the academic study of the Bible in China. He explained that he was making an exception to the rules about allowable content in the WeChat group because the documentary filmmakers, who were married to each other, were WeChat group members themselves and because this installment of their documentary concerned the Hebrew Bible. Wang then described the documentary as tracking a world-renowned Chinese Old Testament Bible scholar as he established Bible study classes in mainland 
China's universities. Wang encouraged group members to pray for this to come about, so that "God's words may long remain in everyone's hearts forever, amen! [thumbs up and thank you emojis]."

One member of the filmmaker couple seized the opportunity to publicize the filmmaking challenges. She thanked Wang for his prayers and support, humbly explained that their film was quite limited in its achievements and expressed hope that God would complement their efforts. Then she explained that ten Old Testament PhD scholars had already been trained and were working as professors at mainland universities. No doubt aware that the members of the WeChat group either included (or themselves knew) wealthy Protestants who might be potential donors, she underlined the high cost of training a single Old Testament scholar (roughly US $\$ 175,000$ ).

This exchange sparked praise by Wang and experience-sharing by others on Bible classes and the Bible's impact. Wang expressed delight and gratitude for the ten scholars, and then asked that all pray that China's universities would one day have departments of Bible studies so university students could take Bible classes. He added a request for prayers for the filmmaking couple who had funded the film despite a difficult financial situation, ending with the exhortation that "Doing work for the Lord never returns empty!" and added "thank you" emojis. One group member then related that when a church "sister" opened a public Bible class in her school, it immediately filled up, suggesting that there indeed is a great thirst in society for learning about the Bible. Another WeChat group member promised to transmit Wang's message further, onto another WeChat group, and then recounted a story about a former classmate's return from the US with her high school aged son. The son had studied the Bible in his American school and quoted its words in normal conversation, even though neither the classmate nor the son were Christians. The conclusion for the WeChat group member was that "the influence of the Bible on them is great" and that "they are all in God's plan."

In these exchanges, WeChat members reinforced convictions that Chinese society is in need of biblical study, as seen in the quickly filled class, and that Bible study can shape the thinking and behavior of even non-believers, such as the high school aged son. Furthermore, the WeChat public could collectively imagine a future in which their current struggles, whether the documentary couple scraping together money for filmmaking and the scholar's years-long efforts to train the next generation of scholars, would result in personal reward and societal transformation.

\subsection{Maintaining a Focus on Bible Handcopying through Discipline and Purposeful Ignoring}

So far, we have seen few, if any, references from the WeChat Bible handcopying public to the currently existing challenges and pressures of practicing Christianity in China. This is remarkable, given that the term "digital religion" (Campbell 2013, pp. 3-4) as a concept developed to emphasize the deep integration of online and offline religious spheres. However, in the authoritarian Chinese context, the discourse in the WeChat group was remarkably divorced from discussion of the practical realities of life that did directly relate to Bible handcopying. When mention of regime pressures on Christianity did surface, they occasioned little comment and discussion returned to the Bible handcopying, perhaps as a way to reduce the chance that the state might scrutinize it as a site of oppositional politics or perhaps to avoid the possibility that Bible handcopiers' conflicting theologies, church positions, or attitudes toward state policies might provoke sharp disputes.

For example, one WeChat member began a post by expressing how much her family was gaining from copying the Bible and "also hold[ing] onto the precious words of God," precisely the goal of the project. She continued, "In my hometown, the government is now confiscating church property and burning Bibles and other spiritual literature." The administrator quickly replied, "Peace! Only look to God! Seek God's absolution! Ask God to have mercy and protect our churches! May God's words remind and protect us every moment not to forget the Lord's grace! At any time we can realize the Lord's intention a little more! Give it over and look to God! Emanuel [God is with us]!" followed by praying-hands symbols. When the member responded, "Amen," another group member directed her to "encourage the church to distribute Bibles" to the church members, to which the original member 
replied that everyone already had Bibles, and then posted photos of a young girl copying a Bible, explaining that she brought her daughter to copy the Bible.

Rather than address the state harassment, ask for prayers for the church under attack, or suggest survival strategies such as dispersal into small groups, the organizer and administrator and others purposefully ignored the chance to better understand the political situation and instead focused on encouraging the mother in her and her family's copying of the Bible. Similar inaction or silence met the posting of a link to a half hour podcast that criticized the authorities' recent demand for church leaders to earn government "preaching certificates" (and that preachers concentrate $70 \%$ of sermon time extolling socialism's benefits rather explaining biblical themes).

In contrast to digital religion's integration of off- and online realms, here we see a sharp divide between the realm of Bible handcopying, where diligent manual copying work and congregational celebrations for completed handcopies form an idyllic image that excludes offline harassment. The authorities are invisible, presumably acting in a realm beyond the cultivated image of Bible handcopying.

The strict focus on Bible handcopying was maintained through light reprimands and a reiteration of the group norms by the administrator, the one who daily posted the latest lists of the various Bible handcopying categories. Over the course of our six-month observation of the WeChat group, every one or two weeks some group member would post a link to an unrelated topic, behavior that violated explicit group rules. ${ }^{11}$ Whether the content was Christian themed or not, the administrator frequently, though not always, chided the violator.

For example, one member posted an advertisement for a music class in guitar, piano, and other instruments, and then, several weeks later, reposted the information. Another person posted a message about a marriage devotional by a famous American evangelical (John Piper). A third person posted a 5-min video clip from a TV talk show about a miraculous healing technique with no Christian reference at all. After each of these instances, the administrator reminded the group of its purpose.

In these reproaches, the administrator typically began with, "[WeChat handle of offending member] Jesus loves you! The Lord bless you! Thank you for your understanding and support" and then posted the "Bible handcopying rules" which were to promote churches and family members to copy the Bible. The rules indicated that the WeChat group only welcomed posts, questions, experiences, and photos related to handcopying the Bible. They also included the goal to "promote a deeper understanding of the true way, life growth, and steadfast service." Infrequently, the censured members responded with contrition.

The WeChat Protestant public, despite being mostly focused on Bible copying themes, also was a site for information that was lightly or not at all related to the activity, just as public spheres are not always single-issue settings. These miscellaneous postings did not always prompt reprimands from organizers, such as a single-page advertisement for a free Bible dictionary and a link to a song praising Jesus ("Ah Lord, you're the most beautiful"). An even odder posting also received no comment: a video contrasting childrearing in the US and China with the aim of encouraging Chinese parents to raise their children to be more self-reliant, as American parents supposedly do. Stranger yet was the link to a five-minute news report about a traffic accident. Perhaps because the group members were known to the organizer, or otherwise posted relevant information (the traffic accident was posted by the person who sent daily devotionals) or their posts were judged to be sufficiently related to the core activity (e.g., the Bible dictionary) and therefore merited no censure. Interestingly, however, other group members did not engage or comment on the posts either, as if the group norms to focus on Bible copying had taken hold among them.

11 In general, the original host of a WeChat group sets its rules and is the only one capable of expelling a member, although any existing member can add a new member into the group. 
Similarly, discordant postings provided fresh opportunities for the group to reaffirm its shared identity and Christian focus. One day, a violent sticker appeared that depicted a cartoon pig firing bullets from a machine gun with the words, "[I] beat you to death (dasi ni)" from a WeChat handle with a woman's name (it turned out to be a joke by the child of a group member who the organizer did not know.) The organizer responded with a puzzled sticker and, before long, other group members criticized the posting and defended the organizer by chiming in with Christian scripture references. First, an image of a handwritten page was posted with a scripture verse, "Like a gold ring in a pig's snout is a beautiful woman without good sense" (Psalm 11: 22). Five minutes later, another person posted a Bible verse, "Better a patient person than a warrior, one with self-control than one who takes a city" (Psalm 16: 32). Both scripture verses seemed to criticize the posting member and quickly received approbation from others. The violent moment thus passed, and the administrator once more turned to posting the daily lists of handcopiers. In this way, the group norms of the WeChat public were reaffirmed, and the public setting once again return to its focus.

\section{Bible Handcopying Movement as Protestant "alter-public" and Implications}

The 2019 Bible handcopying movement in China originated from an online call to expand a new form of offline religious devotion in handcopying the Bible and sparked the development of a small-scale public in a 500-member social media group on China's WeChat app. Its grassroots origins, group membership including strangers, shared awareness of subordinate status, and its peculiar forms of discourse mark this WeChat group as a type of public, similar in character to evangelistic and pietistic conservative unregistered "house churches" in China, but also highly original in prompting nationwide - even international—participation of Chinese Protestants without reference to denominational or house church network groupings.

Unlike studies of digital religion in liberal democratic regimes in advanced economies, this analysis focuses attention on the character of the state and its influence on society. The threat of authoritarian Chinese regime intervention circumscribes the range of topics aired in the WeChat public and underscores the importance of a narrow focus. Given these limitations, it is best understood as an "alter-public," rather than a full-blown public sphere or an example of Warner's "counterpublics" (2002), drawing on Thomas Chen's work on how online censorship reworked the content of a novel posted online to produce a new text (Chen 2015). By recognizing the possibility of oppositional outcomes without reducing the effect to a binary struggle between state and society or domination and resistance (Chen 2015, p. 21), the alter-public term encompasses the possibility of state opposition without singling it out. So even without state intervention, fear of state intervention shapes the nature and content of the discourse circulating in the WeChat group. ${ }^{12}$

For Protestants, the "alter-public" WeChat space promotes another identity that empowers a modus vivendi for Protestants living under a powerful Party-state. Chinese Bible copiers can thus be loyal citizens and also members of an eternal community, that of "the saints" of the universal church. In this way, the WeChat encouragement through electronic stickers and the envisioning of the community through photos and videos of Bible copiers employs a virtual community online to draw participants into another unseen (but not virtual) religious community that must be imagined across time and across space, that of the communion of the saints. Protestants can understand themselves through the lens of multiple identities: loyal Chinese citizens subordinate to the Party-state and also Bible scribes who composed the Bible.

Methdologically, in conceptualizing the Bible handcopying movement as a Protestant alter-public we argue that even micro-scale publics or public spheres of hundreds of people are important to study (Keane 1998, p. 170), because they provide insight into larger phenomena, such as how citizens react to

12 It may also be that Wang Wenfeng set up the WeChat group rules in such a way to avoid endless, fractious disputes in society, between the range of Protestants engaged in copying the Bible. 
the Party-state, and their existence suggests that the state permits (or is unaware of) "bubbles" of partial autonomy where religious practices of subordinate groups can percolate (McCallum 2011, p. 184). By contrast with the Habermasian concept of public spheres, however, this Protestant alter-public is most assuredly not a space of rational-critical debate (Habermas 1962). Instead, it functions like a performative "poetic" space (Warner 2002), which means that the political concerns of its participants are almost completely invisible, because popular encouragement for religious practices displaces rational-critical debate of political issues.

By contrast with scholars of democratic regimes who argue that the concept of multiple micro public spheres helps illuminate religious groups' interactions within and beyond their communities (McCallum 2011), in an authoritarian context the Protestant alter-public acts as a micro structure that discourages broader discussion, because it hives off any mention of political issues into smaller scale settings. This closure is apparent, as others have noted with WeChat (and in contrast to Weibo microblogs) (Harwit 2017, p. 318), in that it is a more intimate venue because only someone who knows a WeChat group member can gain admission to the group. So rather than being fully open to strangers, the Protestant WeChat alter-public is only partially open. ${ }^{13}$ Second, it implies that by sequestering dialogue or discussion of religious practices into smaller venues and casting it as having an alternative rather than oppositional character, alter-publics may well stabilize the Party-state, because if alternatives were to develop into opposition, such nascent critiques would still be somewhat cordoned off from wider society. ${ }^{14}$

Studying the 2019 Bible handcopying movement and its WeChat alter-public helps answer the call for investigation of online religious engagement in China (Xu and Campbell 2018, p. 254) and, more broadly, it offers an example of how one religious group has sought to use online religion to bolster offline religious practices and communities. In the process, the movement and its micro-public are emphasizing a Protestant identity to coexist alongside a Chinese citizenship identity and as an antidote to the side effects of rapid social change in China.

Author Contributions: The idea for the article came from J.H., who also conducted interviews and contributed his extensive background knowledge; J.H. and C.V. developed the formal analysis jointly; the investigation (collection of WeChat data), conceptualization of the alter-public, writing-original draft preparation, and most of the writing-review and editing was completed by C.V.

Funding: This research received no external funding.

Conflicts of Interest: The authors declare no conflict of interest.

\section{References}

Anderson, Benedict. 1983. Imagined Communities: Reflections on the Origin and Spread of Nationalism. New York: Verso.

Bays, Daniel H. 2003. Chinese Protestant Christianity Today. China Quarterly 174: 488-504. [CrossRef]

Bays, Daniel H. 2011. A New History of Christianity in China. Malden: Wiley-Blackwell.

Berlant, Lauren. 2008. The Female Complaint: The Unfinished Business of Sentimentality in American Culture. Durham: Duke University Press.

Campbell, Heidi A. 2013. Introduction: The Rise of the Study of Digital Religion. In Digital Religion: Understanding Religious Practice in New Media Worlds. Edited by Heidi A. Campbell. New York: Routledge.

13 The public concept still holds, however, as Warner's original conception of publics had similar limitations in that not everyone knew about the existence of the She-romp counterpublic.

14 "Somewhat," because daisy-chain messaging can spread ideas from a 500-member group to other groups, again and again, thus reaching a larger group of people. Also, the Bible handcopying movement does claim public goals to reach out to wider society, for example, with a number of memorializing efforts. In the WeChat group, Wang Wenfeng repeatedly mentioned his plans to establish a Bible handcopying museum to discuss the history of the Chinese Bible and display the handwritten pages and scrolls he has received from individuals and congregations in China and abroad. In addition, individual church congregations have begun publishing their handcopying sheets as bound volumes to serve as a memoriam for the effort. 
Cao, Nanlai. 2011. Constructing China's Jerusalem: Christians, Power, and Place in Contemporary Wenzhou. Palo Alto: Stanford University Press.

Cao, Nanlai. 2017. Spatial Modernity, Party Building, and Local Governance: Putting the Christian Cross-Removal Campaign in Context. The China Review 17: 29-52.

CCCTSPM.org. 2018. Pushing Forward Our Country's Protestant Five-Year Work Plan Principles (2018-2022) for the Sinicization of Christianity (Tuijin Woquo Jidujiao Zhongguohua Wunian Gongzuojihua Gangyao (2018-2022)). Shanghai: CCCTSPM.org.

Chau, Adam Y. 2012. Script Fundamentalism: The Practice of Cherishing Written Characters (Xi Zizhi) in the Age of Literati Decline and Commercial Revolution. In Chinese and European Perspectives on the Study of Chinese Popular Religions. Edited by Philip Clart. Taipei: Boyang Publishing.

Chen, Jianming. 2008. Modern Chinese Attitudes Toward the Bible. In Reading Christian Scriptures in China. Edited by Chloë Starr. New York: T \& T Clark, pp. 13-31.

Chen, Thomas. 2015. The Workshop of the World: Censorship and the Internet Novel 'Such is This World'. In China's Contested Internet. Edited by Guobin Yang. Copenhagen: NIAS Press, p. 19.

Dunch, Ryan. 2001. Protestant Christianity in China Today: Fragile, Fragmented, Flourishing. In China and Christianity: Burdened Past, Hopeful Future. Edited by Stephen Uhalley Jr. and Xiaoxin Wu. Armonk: M.E. Sharpe, pp. 195-216.

Entwistle, Phil. 2016. Faith in China: Religious Belief and National Narratives Amongst Young, Urban Chinese Protestants. Nations and Nationalism 22: 347-70. [CrossRef]

Fraser, Nancy. 1990. Rethinking the Public Sphere: A Contribution to the Critique of Actually Existing Democracy. Social Text 25/26: 56-80. [CrossRef]

Habermas, Jurgen. 1962. The Structural Transformation of the Public Sphere: An Inquiry into a Category of Bourgeois Society. Boston: The MIT Press.

Hao, Zhidong, and Yan Liu. 2018. Mutual Accommodation in the Church-State Relationship in China? A Case Study of the Sanjiang Church Demolition in Zhejiang. Review of Religion and Chinese Society 5: $26-42$. [CrossRef]

Harris, Rachel. 2018. Dissonant Voices in China's Harmonious Society: From Cassettes to WeChat, Nation to Anashid. In The Oxford Handbook of Protest Music. Edited by Manabe Noriko and Drott Eric. Oxford: Oxford University Press, Forthcoming.

Harris, Rachel, and Aziz Isa. 2018. Islam By Smartphone: Reading the Uyghur Islamic Revival on Wechat. Central Asian Survey 38: 1-20. [CrossRef]

Harwit, Eric. 2017. Wechat: Social and Political Development of China's Dominant Messaging App. Chinese Journal of Communication 10: 312-27. [CrossRef]

Helland, Christopher. 2000. Online-Religion/religion-online and Virtual Communites. In Religion on the Internet: Research Prospects and Promises. Edited by Jeffrey K. Hadden and Douglas E. Cowan. New York: JAI Press.

Hoover, Stewart, and Nabil Echchaibi. 2012. Working Paper Media Theory and the 'Third Spaces of Digital Religion'. Boulder: The Center for Religion, Culture, and Media, University of Colorado.

Huang, Weishan. 2016. Wechat Together About the Buddha: The Construction of Sacred Space and Religious Community in Shanghai Through Social Media. In Religion and Media in China. Edited by Stefania Travagnin. New York: Routledge, pp. 110-28.

Hunter, Alan, and Kim-Kwong Chan. 1993. Protestantism in Contemporary China. New York: Cambridge University Press.

Jenner, William F.J. 1992. The Tyranny of History: The Roots of China's Crisis. London: Penguin Press.

Johnson, Ian Denis. 2013. Q. \& A.: Yang Fenggang on the 'Oxford Consensus' and Public Trust in China. New York Times, October 13.

Kang, Jie. 2016. House Church Christianity, From Rural Preachers to City Pastors. Basingstoke: Palgrave Macmillan.

Keane, John. 1998. The Media and Democracy. Cambridge: Polity Press.

Koesel, Karrie J. 2013. The Rise of a Chinese House Church: The Organizational Weapon. The China Quarterly 215: 572-89. [CrossRef]

Kuo, Cheng-tian. 2011. Chinese Religious Reform. Asian Survey 51: 1042-64.

Lee, Joseph Tse-Hei. 2014. The Bible and the Gun: Christianity in South China, 1860-1900. New York: Routledge.

Lee, Cyrus. 2019. Daily Active Users for Wechat Exceeds 1 Billion. ZDNet. Available online: https://www.zdnet. com/article/daily-active-user-of-messaging-app-wechat-exceeds-1-billion/ (accessed on 9 January 2019). 
Lu, Xin. 2019. Give Your Church to the State or We Demolish it. Bitter Winter. Available online: https: //bitterwinter.org/give-your-church-to-the-state-or-we-demolish-it/ (accessed on 25 July 2019).

Lutz, Jessie G. 1988. Chinese Politics and Christian Missions: The Anti-Christian Movements of 1920-1928. Notre Dame: Cross Cultural Publications.

McCallum, Richard. 2011. Micro Public Spheres and the Sociology of Religion: An Evangelical Illustration. Journal of Contemporary Religion 26: 173-87. [CrossRef]

McDonald, Tom. 2016. Social Media in Rural China, Social Networks and Moral Frameworks. London: UCL Press.

McMillan, David W., and David M. Chavis. 1986. Sense of Community: A Definition and Theory. Journal of Community Psychology 14: 6-23. [CrossRef]

New York Times. 2013. Full Text of the Oxford Consensus. October 18. Available online: https://sinosphere.blogs. nytimes.com/2013/10/18/full-text-of-the-oxford-consensus-2013/ (accessed on 18 October 2013).

Ren, Yuan. 2018. Know Your Chinese Social Media. New York Times. November 19. Available online: https:/www. nytimes.com/2018/11/19/fashion/china-social-media-weibo-wechat.html (accessed on 19 November 2018).

Scottish Bible Society. 2019. 100 Years of the Chinese Union Version (CUV) Bible. Available online: https://scottishbiblesociety.org/2019/04/100-years-of-the-chinese-union-version-cuv-bible/ (accessed on 23 September 2019).

Tang, Shiwen. 2019. Publication of the Union Version Bible and the New Culture Movement (Heheben "Shengjing" Yu Xin Wenhua Yundong). Zhongguo Minzu Zhongjiao Wang (China Ethnic Minorities and Religion Website). Available online: http://www.mzb.com.cn/html/report/190136770-1.htm (accessed on 29 September 2019).

Tarocco, Francesca. 2019. Charismatic Communications: The Intimate Publics of Chinese Buddhism. In Concepts and Methods for the Study of Chinese Religions III. Edited by Paul R. Katz and Stefania Travagnin. Berlin: De Gruyter, p. 113.

Travagnin, Stefania, ed. 2016. Religion and Media in China, Insights and Case Studies from the Mainland, Taiwan and Hong Kong. New York: Routledge.

Vala, Carsten T. 2013. Protestant Reactions to the Nationalism Agenda in Contemporary China. In Christianity in Contemporary China. Edited by Francis K.G. Lim. New York: Routledge.

Vala, Carsten T. 2018. The Politics of Protestant Churches and the Party-State in China: God Above Party? New York: Routledge.

Vala, Carsten T. 2019. Protestant Resistance and Activism in China's Official Churches. In Handbook of Protest and Resistance in China. Edited by Teresa Wright. Northampton: Edward Elgar, pp. 316-30.

Vala, Carsten T, and Jianbo Huang. 2016. Three High-Profile Protestant Microbloggers in Contemporary China: Expanding Public Discourse or Burrowing Into Religious Niches on Weibo. In Religion and Media in China, Insights and Case Studies from the Mainland, Taiwan and Hong Kong. Edited by Stefania Travagnin. New York: Routledge, pp. 167-86.

Vala, Carsten T., and Kevin J. O'Brien. 2007. Attraction Without Networks: Recruiting Strangers to Unregistered Protestantism in China. Mobilization 12: 79-94.

Warner, Michael. 2002. Publics and Counterpublics. New York: Zone Books.

Weixin QQ. 2019. Zhuanti Fangtan: Wang Wanfeng- Shouchao Shengjing De Zhongyao Yiyi (Special Interview: Wang Wenfeng-The Special Meaning of Handcopying the Bible). Weixin QQ, February 18.

Xu, Shengju, and Heidi A. Campbell. 2018. Surveying Digital Religion in China: Characteristics of Religion on the Internet in Mainland China. The Communication Review 21: 253-76. [CrossRef]

Yan, Yunxiang. 2010. Introduction: Conflicting Images of the Individual and Contested Process of Individualization. In iChina, the Rise of the Individual in Modern Chinese Society. Edited by Mette Halskov Hansen and Rune Svarverud. Copenhagen: Nordic Institute of Asian Studies.

Yang, Fenggang. 2018. Failure of the Campaign to Demolish Church Crosses in Zhejiang Province, 2013-2016. Review of Religion and Chinese Society 5: 5-25. [CrossRef]

Yen, Yuehping. 2005. Calligraphy and Power in Contemporary Chinese Society. New York: RoutledgeCurzon. 
Zetzsche, Jost Oliver. 1999. The Bible in China: The History of the Union Version or the Culmination of Protestant Missionary Bible Translation in China. Nettetal and Sankt Augustin: Routledge.

Zhang, Laney. 2017. China: Revised Regulations on Religious Affairs. In Global Legal Monitor. Available online: https://www.loc.gov/law/foreign-news/article/china-revised-regulations-on-religious-affairs/ (accessed on 6 August 2019).

(c) BY

(C) 2019 by the authors. Licensee MDPI, Basel, Switzerland. This article is an open access article distributed under the terms and conditions of the Creative Commons Attribution (CC BY) license (http://creativecommons.org/licenses/by/4.0/). 

Article

\title{
Being Christian through External Giving
}

\author{
Steve Wai Lung Cheung ${ }^{1}$ and Khun Eng Kuah ${ }^{2, *}$ \\ 1 Department of Sociology, University of Hong Kong, Pokfulam 999077, Hong Kong, China; stevecwl@hku.hk \\ 2 School of International Studies and Academy of Overseas Chinese Studies, Jinan University, \\ Guangzhou 510632, China \\ * Correspondence: KUAHKHUNENG@jnu.edu.cn
}

Received: 17 July 2019; Accepted: 10 September 2019; Published: 13 September 2019

\begin{abstract}
This study examines how Christian informants understand and practice external (charitable) giving outside of their church, both in terms of money and volunteering time and effort. While existing quantitative researches have informed us primarily about the determinants of giving in the West, we carry out a small case study in a church in an Asian city of Hong Kong to explore how local Christians understand and practice external giving. It is found that external giving is not just an obligatory religious code of conduct that the Christians are obliged to follow. More essentially, drawing reference from the concept of technology of the self, we argue that giving is an integral part of the making of the Christian self. Through giving, individual Christians redefine, transform, and enact their sacred selves in relation to God and others in the community of the faithful. At a collective level, external giving contributes to the construction of a sacred moral economy, which places Christian givers and the needy recipients in a transcendent social relationship. In this state of transcendent social relationship, the givers and recipients are all children of God, hence of equal status. As such, the secular social distinction and material hierarchy distinction between these two groups pales into insignificance. Furthermore, we argue that while secular considerations of economic rationality colour how Christians select the recipients of their giving, these practical concerns are also spiritualized and incorporated into their logic of Christian morality.
\end{abstract}

Keywords: religious giving; Christianity; technology of the self; moral economy; Christian morality

\section{Introduction}

The virtues of compassion and caring for others are overarching moral principles being commonly advocated by major world religions. Many religious scriptures explicitly prescribe giving and charity as a religious obligation. For instance, the idea of 'dana' is found in Hinduism, Buddhism, and Jainism, prompting believers to carry out charitable acts (Heim 2004). In Islam, 'Zakat' is one of the foundational pillars in religious teaching, which can be understood as an obligatory gift all Muslims should make from their wealth beyond the basic necessities (Queen 1996, p. 47). In Christianity, giving occupies a central role in the practice of faith. For years, tithing - in a simple term, the giving of $10 \%$ of one's income-has been an institutional form of giving Christians were expected to give to the church ${ }^{1}$. Beyond the church setting, Christians are also guided by Biblical teaching to engage in giving acts in everyday life. For instance, as the holy text teaches, "whatever you did for one of the least of these brothers and sisters of mine, you did for me." (Matthew 25: 40) Caring acts are interpreted as serving God directly. These giving acts are important to the faith-driven individuals not just for fulfilling their inner religious duties; they also serve as a crucial pathway for their civic engagement and contribution to the broader society (e.g., Wuthnow 1999; Putnam 2000; Becker and Dhingra 2001).

1 For a quick historical review of the development of tithing, one can consult Quiggle (2009). 
In this study, an anthropological analysis is carried out to explore how individual Christians in Hong Kong make sense of and practice external giving. In our study, 'external giving' refers to donations of money, time, and other resources to non-church, non-religious entities such as the NGOs and individuals in needs. While some scholars might specifically coin it as 'secular giving' (Bekkers and Wiepking 2011, p. 7), we deliberately select the term 'external giving' to blur the sacred-secular distinction. As we will see in Section 3.2, external giving is ambiguously defined by our informants. Some informants regard giving to non-Christian secular charitable groups as similar to giving to church although some others differentiate between secular and Christian giving. In this paper, we define 'external giving' according to our informants' perspective.

The data discussed in this paper is part of a bigger research project on Christian giving. An ethnographic case study of a local community church in Hong Kong called the Church of Benevolence (a pseudonym) $)^{2}$ was conducted. In-depth, semi-structured interviews with 50 church members/regular attendants were conducted between 2015 and 2018. There were 23 male informants and 27 female informants, who were aged between 18 and 74 . These informants consisted of general lay members, lay leaders, and the pastoral staff. As a member of the church, Steve Cheung, through interviews and participant-observation, builds strong rapport with the informants and collect valuable data ${ }^{3}$. One key issue concerns how and why informants engage in giving and volunteering beyond their own church. Interview questions were directed towards informants' perception and practices of giving beyond their church ${ }^{4}$ were probed during the interviews.

In the following, we will first begin with a brief literature review of the relationship between religion and external giving. As we will see, a handful of literature has shown a positive relationship between the two, and many of these quantitative studies have contributed to our understanding of the determinants of the giving. Moreover, this academic field is dominated by scholarly studies on giving in the Western Christian context. Yet, researches on individual Christians' engagement and perspectives on external giving in a region where Christianity is not the dominant religion-like the case in Hong Kong-are relatively scarce. It is hoped that this paper will provide relevant data and discussion to fill the gaps in the literature. Next, we will proceed forward to present and discuss how our Christian informants, from their emic perspective, discursively understand and practice external giving. Three key findings will be brought up and elaborated: First, how Christians make and transform their Christian selves through external giving; second, how they cognitively and behaviourally distinguish between church giving and external giving; and third, how it impacts their selection of the target groups for their giving. Drawing upon all these findings, we will attempt an analysis on our understanding of the complexity that surrounds the nature and essence of Christian giving, especially on external giving.

\section{Approaching Religion and External Giving}

The topic of giving has attracted attention among scholars in different fields like philanthropic studies (Hodgkinson et al. 1996) and sociology of religion where an entire volume is devoted to religious philanthropy in Review of Religious Research in 1994. Scores of academic literature have discussed how different dimensions of religiosity have encouraged believers to engage in religious giving (Lincoln et al. 2008). At the same time, studies have also shown a positive correlation between external giving and religiosity, particularly between external giving and religious attendance and membership (Jackson et al. 1995; Bekkers and Schuyt 2008; Helms and Thornton 2012; Forbes and Zampelli 2013; and Bekkers

2 This Church is a small Baptist church located at a kindergarten in a public housing estate in Hong Kong. By 2017, it has 140 registered members, with an average weekly attendance of 110 people.

3 All quotes from the informants appeared in this paper are found in Cheung's PhD thesis. See Cheung (2019), chp. 7 ("Giving beyond the Church").

4 Scholars have reminded us that we have to make separated analysis between religious and non-religious giving, hinting that the determinants of these two kinds of giving are different (e.g., Kitchen 1992; Chan and Lee 2016). 
and Wiepking 2011). ${ }^{5}$ These researches provide rich statistical data to understand the correlates and determinants of the giving acts from a quantitative perspective. In our paper, we explore religious and external giving from a qualitative perspective by studying the subjective experiences and rationale of giving of individual givers. Hence, this current study hopes to fill this missing puzzle.

One key issue in this paper explores the correlation between external giving and volunteerism. There are two key theoretical perspectives which guide our understanding of the relationship between religion and volunteerism (Becker and Dhingra 2001; Ruiter and Graaf 2006; Van Tienen et al. 2011; Yeung 2018). One perspective is the 'network explanation theory', which highlights how external social contacts and ties among believers, sometimes facilitated by the church organizations, could trigger and increase their likelihood to participate in volunteerism. For instance, church attendants learn from their fellow church members about specific voluntary organizations and their volunteering opportunities. A second perspective is a value-orientation approach, which focuses on the role of beliefs and values in shaping the individuals. This perspective argues the subtle internalization of religious values of altruistic and pro-social practices that encourages individual volunteering. As Wuthnow (1991, p. 159) finds, Christian informants routinely recount specific Biblical stories like the Parable of Good Samaritan, rather than theological reasons, to account for their charitable actions. Furthermore, as Son and Wilson (2012) suggest, the normative internalization of these prosocial religious messages bring believers a moral obligation and identity to serve as volunteers.

At present, the literature on religion and giving is very much dominated by studies on the European and, in particular, American Christian scenes (Lincoln et al. 2008). There are a growing number of academic endeavours to extend this research field to the other cultures like Chinese societies where Christianity is rapidly gaining grounds. Among this pool of scholarship, there are two key lines of studies. The literature that follow the quantitative tradition tends to examine the correlates between different dimensions of religiosity (taken into consideration Eastern religions like Buddhism, Taoism, and popular religion), the level of giving and some other factors. For instance, Chang's (2005) examination on the data of the Survey of Social Development Trends shows a positive connection between age and both religious and charitable monetary giving in Taiwan. More recently, Terazawa's (2015) analysis on the data from the Taiwan Social Change Survey suggests that different kinds of religiosity in Taiwan have different effects on religious and secular volunteering, with religious participation having a stronger impact on religious volunteering but not secular volunteering. At the same time, spiritual behaviours like practicing yoga and reading spiritual books appear to be powerful determinants for both religious and secular volunteering. Another line of literature probes at the dynamic interaction between the religious organization, individual believers, and even the state, through the lens of religious volunteerism. In her study on religious charity in China, drawing from the experience of a Catholic and a Buddhist charitable group, respectively, McCarthy (2013) touches upon how these groups cooperate with the state in organizing social services and mobilizing their volunteers to serve the society, while at the same time repurposes the state for religious ends. In Taiwan, a number of studies on socially engaged Buddhism, notably on religious charity groups such as Tzu Chi association, have open dialogue and help us understand how religious volunteers (especially female volunteers) practice Buddhist teaching of compassion through their services. This process not only effects spiritual transformation and empowerment of these Buddhists, but also contributes to the development of its unique organization structure (Huang 2009; O’Neill 2010; Yao 2012).

In our current discussion, we seek to explore how Christians in Hong Kong understand and practice external giving. Theoretically, we adopt the value-orientation track to examine how informants' subjective interpretation and reflection of the Christian teaching affect their giving behaviours. However, instead of seeing religious teaching simply as an independent factor motivating believers to take giving

5 However, a minority of the studies shows counter or ambivalent results over the positive relationship between religiosity and external giving. See Lyons and Nivison-Smith (2006) and Sablosky (2014). 
as a religious obligation, we will argue how, inspired by their understanding of religious teaching, external giving serves as a technology for these Christian believers to undergo spiritual transformation and the making of their Christian selves.

\section{Discussion: Being Christians through External Giving}

\subsection{External Giving and the Christian Self}

When it comes to the topic of religion, there is a popular Chinese saying which conveys the meaning that "all religions guide people to be benevolent" ${ }^{\prime}$. From an essentialist point of view, one might argue that giving is simply a religious duty that every Christian should enact. However, in our findings, as expressed by our informants about their views and experiences on giving to charity, there is no clear articulation between their giving and their faith. Most informants would say that they simply want to help people, particularly the needy. It is only through in-depth probing that we unveil how Christian faith implicitly and subtly affects their giving acts.

Drawing from our data, we argue that there is a linkage between external giving and the making of the Christian self. Here, we borrow the theoretical insight from Michel Foucault's notion of the 'technology of the self'. On the topic of subject and the self, Foucault $(1988,1990)$ discusses the application of 'technology of the self' by individuals to discipline and transform themselves into desirable ethical subjects. To actualize and become the ethical self, Foucault points out the importance of 'ethical work', which is the technology applied by individuals voluntarily to "transform themselves, to change themselves in their singular being, and to make their life into an oeuvre that carries certain aesthetic values and meets certain stylistic criteria" (Foucault 1990, pp. 10-11). This notion offers us a useful entry point to analyse the way religious practitioners construct themselves into spiritual subjects. For instance, Palmer and Siegler (2017) show how Daoist practitioners apply technologies like qigong in their cultivation of their Daoist selves. In Christian traditions, there are different technologies, such as doing prayers and reading the Bible, for individuals to nurture their selves. The key to this making of Christian selves is the renunciation of one's ordinary self. As Foucault (1988) writes on early Christian asceticism, "your self is a part of the reality you have to renounce in order to get access to another level of reality." (p. 35). In the current study, we see giving as a specific kind of technology for Christian believers to nurture and realize their Christian selves. In doing the giving, they attempt to transform from their ordinary selves to selves charged with sacred qualities.

We begin with the discursive account offered by informant Aaron on his view over donation. He states,

"Donating to the poor is one of the basic teachings God gives to humans. Throughout the Bible, God wants those who are rich and abundant to help the poor. The former should never exploit the latter. In the Old Testament, like in the Book of Ruth, it is suggested that during harvest time, some grain should be left over for the poor people to pick up....... Moreover, I don't think that I am 'giving alms' to the poor, nor I am 'donating' and 'helping' them. I simply think that providing for the poor is necessary because God (Jesus) also does so. He does not need humans for His existence, but He kindly sends us His son. Likewise, God does not need you to help the poor. He could offer His providence through whatever means."

From Aaron's quote, we see the complex emotions that govern Aaron's understanding of donation and his understanding of the Biblical teaching. Two issues should be noted. First, Aaron does not see donating to the poor simply as a religious command that he needs to follow. This is because he believes that God does not really need this particular 'him' to do the good work. In short, there is no compulsion for him to deliver the act of giving. However, as Christian, he emulates the characteristics

6 In Chinese, “所有宗教都是人向善的”Suoyou zongjiao dou shi dao ren xiang shan de. 
of the compassionate Christ and enacts Christ compassion to the needy. In other words, giving becomes an important aspect that enables Aaron to effect a moral transformation in alignment with the self of Christ. This view on donation and volunteering is widely shared by a sizeable number of informants who mentioned that they are doing these giving "with the love of Christ" (著基督的 daizhe jidu de ai). They cognitively see that their giving is not charged with the compassion out of their humanly selves. Rather, it is the transformed Christian-imbued moral self that propels them to serve the needy with the love of Christ. Another informant, Joseph, makes clear reference to a Biblical teaching that suggests that Christians should imitate Christ to become a humble servant in voluntary services ${ }^{7}$.

The second insight that we draw from Aaron's account is the relationship between the donor and recipient. Under a normal situation, practically and materially speaking, the donor, because of wealth, is materially superior to the recipient, thereby underlying a superior status of the donor. However, in this instance of religious giving, and at least in a discursive sense, Aaron's denial of 'giving alms'/ 'donating'/ 'helping' is an attempt to dissolve this superior-needy hierarchy. This line of logic is more expressively articulated by informants Naomi and Priscilla.

Naomi is a middle-aged woman with modest means and living in a public housing estate. For a period of time, she was not a full-time worker and had to take care of her dependent children. It was a period of financial hardship for her. Nevertheless, during this hard time, she continued to provide financial assistance to a widow friend in her home-town in Mainland China. This informal giving persisted for almost two decades. Here, even though Naomi had limited resources, she continued to be willing to share them with her friend in need. She shared with us her motivation to give as below:

"I don't give simply because of my personal relationship with her. I do have a strong connection with her and her father. But there is something more: she is truly in great need. She once got married and does not have children to take care of her. And I know that she continuously needs money to receive treatments for her chronic diseases. If I stop aiding her, she will die. In Bible, it is said that we need to offer help especially to orphans and widowed. Now you see someone who is in great need. Do you just tell her to go in peace but not giving her any substantial help? ... . . . Actually, I do not just see her as a 'sister' (This lady is a Christian as well), but an important person in God. I don't know why, but I feel that I am obliged to help her even though my own economic condition is not particularly well. It is not just a commitment I have towards a specific lady, but I look at the issue from the perspective of the Kingdom of God. Do you remember Prophet Elijah, who once helped a poor widow in Sidon (a city outside Israel) ${ }^{8}$ ? Actually, in Israel there were also a lot of widows. Why did God send Elijah to pastor a widow outside home? I thank God for putting me in a similar situation-I am living in Hong Kong, a free and affluent city, and I have a chance to help a widow in Mainland China. I know God has His plan on me as well."

In Naomi's account, she finds a parallel between her and a Biblical character, Elijah. She interprets her giving in the context of God's plan. God puts everyone in a certain position with His own plan, and she is positioned in a similar setting as Elijah faced. Eventually, to respond to God's higher plan, she does the similar giving act as Elijah did, even though she is also facing her own financial problems. It is a deep sense of moral commitment in her heart, her moral self, that moves her to give. Alongside with this way of reasoning, she has an interesting perspective on the relationship between her and the widow friend. While materially she appears to be better endowed, spiritually she finds herself and the widow largely on equal footing. She viewed their different status as part of God's plan. Symbolically, she even recognizes this widow friend not just as a 'sister', but an 'important person in God'. Here, we see how the power hierarchy between the giver and the recipient is transcended.

7 The exacting teaching is found in Mark 10:45. The general idea is that Jesus Christ comes to the world to serve, not to be served.

8 See 1 Kings, Chapter 17 in Bible for reference. 
One might cast a doubt that Naomi's case is not strongly evident—after all, the aiding target is a friend she personally knows of, and it might be easy for her to downplay the giver-recipient hierarchy. Here, we might also consider Priscilla's reflection on her volunteering experience. She said,

"In practice, I am 'helping' the others, so to speak. But I try to avoid using this term in order to prevent myself from turning to be arrogant. I don't want to present to the recipients that I am the one with prowess to help, and the recipients are the powerless....... I firmly hold that God has His plan in creating every one of us. Our existence bears its intrinsic value, and this value is originated from God's love. The people in need are located (by Him) at a disadvantaged position. And we, being provided with abilities, are also placed to be living with them in the same time and space, the same community. ...... Actually, giving what we have to them is a blessing to us. At the same time, it is also a way to respond to His love."

Once again, Priscilla's account downplays the idea of 'helping' and neutralizes the power relationship between her and the people she aids. Similar to Naomi, she conceptualizes a transcendental moral community structure: While there is a real material and social division between people, such distinction is set under God's plan, with every position, including the subordinated one, containing its own value. Under God's love, interaction between people in different positions is charged with a moral quality. What is even more remarkable is that, instead of seeing giving as a deprivation act which decreases her possession, Priscilla actually perceives a gain of blessing from it. In her study on female participation in Buddhist volunteerism in Taiwan, Kuah (2015) sheds light on how the ideology of gratitude (感恩 ganen) motivates and guides these volunteers to perform compassion. Essentially, they have to show gratitude to those serving targets who offer them the chance to provide assistance. From their perspective, the significance of their giving is not just about addressing the recipients' needs, but more about how their own spiritual need is addressed when recipients give them the chance to volunteer. Here, in Christian's view on external giving, as exemplified by Priscilla, we can also see that giving actually offers believers an occasion to receive God's blessing. By sharing their material richness to the needy, Christians fill their spiritual poverty with God's provision.

\subsection{External Giving versus Church Giving}

The above sub-section outlined how, in principle, Christians undergo spiritual transformation through external giving. The subject matter concerns more about how individuals make their inner Christian selves and relate their selves with others. We might want to further probe how they outwardly perform and make decisions on external giving. To do so, one meaningful step is to first unpack how Christians understand the nature of external giving. In the course of our research, we discover that our informants adopt a deliberate ambiguous and multi-layered viewpoint to make sense of external giving that is sharply in contrast with a clear and definite understanding of church giving (i.e., giving inside the church).

In the discussion on religion and giving, the relevant literature focuses on the relationship between religious giving and secular giving. In some quantitative studies, it was found that religious participation has motivated believers to do BOTH religious giving and secular giving. In other words, the relationship between these two types of giving could be seen as complementary and hence is not a zero-sum one (e.g., Clain and Zech 1999; Nemeth and Luidens 2003; Hill and Vaidyanathan 2011). Yet, other studies have demonstrated that the generosity of believers on giving is largely confined to donations within churches, instead of spilling over to secular groups (Eckel and Grossman 2004). There are also studies that revealed competition between religious volunteering and secular volunteering although scholars such as Wilson and Janoski (1995) and Campbell and Yonish (2003) have highlighted that active religious participants tend to spend less time on secular volunteering. In these studies, the classification of religious giving/volunteering and secular giving/volunteering is based on the target groups (i.e., religious or secular groups) where the giving goes to. An emic perspective on how 
Christians cognitively and discursively distinguish their giving to the church from giving to secular charitable groups has been overlooked.

From the emic perspective, our informants have qualitatively differentiated between these two kinds of giving. First, our informants use different terminologies to demarcate these giving. In particular, they have two specific emic terms to refer to giving to church. The term 'Offering' (奉 fengxian) is used for monetary offering. This is to differentiate from the general term 'donation' (捐 juan qian). 'Serving' (事奉 shifeng) refers to the provision of time and effort to the church. This is in contrast to the general idea of 'volunteering' (工 yigong) $)^{9}$. In pronouncing 'Offering' and 'Serving', the individuals often refer to giving to the church. In this sense, the church as a site is the destination for the purpose of Offering and Serving. However, there is also a variation to this where some lay members use these two terms of offering and serving beyond the church confines and for external giving purposes. In this sense, there is a blurring of the line between church giving and external giving. Aaron's view on Offering and donation provides a good illustration of this blurring boundary:

"In Bible, it is said clearly that you need to take care of someone who is in a disadvantaged position. God gives us talent to spend the money wisely to assist the needy. It is not always the Christian groups which can do well in providing to them. For instance, my family regularly gives to United Nations Refugee Agency (UNHCR), a non-Christian group, because we trust that they (the organization) can offer help to the refugee...... In a sense, we also consider our donation as Offering because it is only with God's provision on us and His teaching, so that we can express our love to the broader society and the needy."

From Aaron's remark, it is clear that he sees external giving as part of his Serving and Offering to God. In addition, specifically, external giving (donation) is an essential act in the making and actualization of his Christian self. Aaron stresses the talent provided by God as opposed to individually acquired talent. In his own belief, the act of donation is a process of serving that facilitates the activation and enactment of this gifted talent from God and which helps to shape the inner quality of his Christian selves. In his view, it is the motive of giving that defines what constitutes religious or secular external giving. When the act of external giving is made in the name of religious or perceived as a religious cause, then, it is religious giving even though it is made to a secular charity. To him and his group of Christians, such external giving regarded as a direct enactment of faith and gifted talent from God.

Furthermore, the meanings and importance attached to church giving and external giving are influenced by various multi-layered perceptions of the lay Christians. This conceptual distinction also has an obvious consequence over the way they practice giving. In the following, we look at the discursive and reflective accounts given by three informants—-namely Esther, Priscilla, and Daniel, i.e., how they see the differences between giving within (Offering and Serving) and outside (donation and volunteering) the church.

Esther: "I think Offering is more essential than donation. Actually, I am not giving to the church organization per se-not giving to the people and the staff there, but I am Offering my very best to God. Of course, then, giving to God is of paramount importance. It is like an obligation I need to take. But for donation, it is targeted at needy people or organizations. I need to look at the targets and the organizations to judge whether I will donate."

Priscilla: “To me, Offering is a responsibility I have towards God, as well as towards myself. To God, He is our provider, and we need to respond to Him. Bible also teaches us to do Offering. There is no doubt at all that we need to Offer. To myself, it entails whether we acknowledge that we are Christians. It is a matter of identity. If I consider myself truly as a Christian, I could not just claim that I am a Christian. I have to do certain things that fit

9 In this paper, we write 'Offering' and 'Serving' in capital letters to refer to the emic terms used by the Christian informants. 
to that identity correspondingly. I am a Christian, so I Offer and Serve. ... ... However, donation and volunteering are something extra. I find it less imperative to do donation and volunteering than Offering and Serving. The sense of obligation is lower. When I do volunteering work for organizations, I will 'flap my hip and leave' ${ }^{10}$ once after I get the task finished. Yet, for Serving at church, I have a higher expectation on myself and want to do it as best as I can."

Daniel: "The messages one shoulders and delivers are different during Serving and for volunteering. When we volunteer, we are spreading the message defined by the organizations. But when we Serve, we Christians are of course spreading the message of Jesus Christ. I am representing Jesus to serve others, but for volunteering, I just help the organization and share my loving-kindness to the needy. ....... Moreover, you just need to do volunteering out of the capacity you can reach (量力而Liangli er wei). It is not extremely pressing that you have to do it well. However, Serving is of a higher degree of urgency. Even Serving, for instance, for the kids at church is hard and challenging, you will still do so. The feeling is different. Serving bears a sense of mission that I have to accomplish."

At a first glance, one might interpret that, contrary to what we argued in the previous section, these three informants-particularly Priscilla and Daniel—appear to find external giving not directly relevant to their spiritual cultivation, and therefore they might pay less effort into such non-church giving. Here, we would like to clarify that, in Priscilla's and Daniel's comments on external giving, their emphasis is on the specific physical and mundane actions or tasks to be carried out under the instruction of the charitable organizations. To them, these are secular mundane activities that one performs when there is time. Such acts are replaceable. Thus, these acts are considered to be of lesser weight compared to religious acts. However, when it comes to the concrete services for the needy, it is their Christian spirituality that shapes their giving actions. In Priscilla's case, it is her understanding of the Christian logic that propels her actions and with the people she serves. For Daniel's case, he sees his volunteering engagement in an elderly service as providing him an occasion to enact and express Christ's love.

In the above three case examples, we aim to draw attention to how our informants attached different levels of importance in the making of their Christian selves through church giving and external giving. We observe a scaling of the level of spiritualization according to the informants' subjective understanding and performance of church giving vis-a-vis external giving. This is reflected in two aspects. One aspect concerns the destination of the giving. Many informants like Priscilla view church giving as a religious act to respond to God's grace and provision. Other informants like Esther, explicitly or implicitly, see that their church giving goes directly to God, even though their giving is channelled to the church organization. In other words, the church organization is symbolically and cognitively conceived as the direct embodiment of God. As a result, there is a strong sense of moral obligation for them to provide money and time when doing church giving. Among this group of informants, the imperative for doing external giving is not as strong. While external giving also bears religious significance and runs in consistent with Christian teaching on compassion, its target is not directly God Himself but the secular organizations or people in need. In this sense, the destination of external giving is perceived to be less sacred but more human/secular when compared to church giving.

The scaling of the levels of spiritualization is also related to the nature of giving. Many informants expressed different interpretation on the significance of the resources (money and volunteering tasks) involved in the two kinds of giving. As a consequence, they also hold different attitudes when practicing giving — that of divine duty or secular duty. For instance, both Priscilla and Daniel regarded

10 'Flap one's hip and leave' is a direct translation from a Cantonese slang 拍拍柚就走 said by Priscilla, which means that one can leave easily without any consequence. 
giving money and time to the church as a direct involvement in God's holy work, hence it is divine duty. It therefore requires the believers to have full commitment and meticulous attitude and performance in the delivery of sacred giving. When it comes to external giving and volunteering, it is considered as secular duty and is seen as supplemental to the core divine duty. For secular duty, the informants have imposed fewer self-demand and self-expectation on themselves in performing the tasks.

Given that external giving is sometimes seen as non-divine duty, it carries a lower degree of urgency and hence, provides more flexibility for individual believers to decide on whether they should do it, and, if affirmative, how they should give. Yet, even when external giving is considered as divine duty (e.g., utilizing the wealth and talent gifted from God to serve the poor), the making of the Christian self is sometimes also coloured by secular reflexivity where pragmatic concerns and calculation (e.g., not exceeding one's normal capacity of effort) are often taken into account. The emic contrast on church giving and external giving as divine and secular duty enables us to get a better sense of how Christians live out their sacred and profane selves through external giving and the complexity that surrounds the religious-secular logic of giving.

\subsection{Where Does External Giving Go to?}

In the following sub-section, we will present how Christians make their decision on external giving. In the selection of the charitable organisations of their external giving, personal consideration and knowledge of the charitable organisations are two important criteria. For instance, informant Ruth provided a personal reason for making a regular donation to Orbis, an international NGO dedicated to sight-saving. She accounted it to the experience of one of her family members who got a sight illness, saying that she would like to offer assistance to people who also suffer from similar problems.

Another selection criterion concerns the informant's knowledge on the charitable organizations. Informants often look at how the charitable organisations operate, particularly the financial accountability and transparency of the charitable organizations. They will be willing to provide external giving to those with solid integrity and good reputation in using the resource and avoid giving to organizations that incurred huge administrative costs. Another key concern is the effectiveness of the organization in managing and channelling the resources to help the needy. Here is a crucial note: While such secular considerations are less likely to be considered in church giving, the informants made conscious attempts to understand the operation of the charitable organization when making external giving. For an illustration, Sarah's view over Offering and donation is a remarkable one.

"My impression on Offering is that we can do it in a free-handed way, and somehow after we give to the church, we generally don't express a strong care on how the people (leaders at church) spend the money. But donation is different. Before I make my donation decision, I will screen and get information from my friends and others over how well the organizations use the money. I can't stand if the organization is doing badly in administration and I will not donate to it. ...... The difference here is on the people: People at church are not professional. They are just volunteers in the church organization. Even though there is a few Serving church members who are full-time staff working in the financial division in the business world, church finance is different from the type of finance they are good at. However, people in those charity organizations are hired staff and are supposed to be professional! They should be more knowledgeable and skilful in managing money."

Informants like Sarah see their giving to the church as divine duty and hence absolute giving. Therefore, secular concern over how well the church uses the money is not a primary concern of their contribution to the church. However, external giving is secular duty and hence, informants have a higher expectation over the effectiveness and accountability of the receiving organizations in managing their giving. While the informants differentiate between these two types of duties, it is evident that the performances of both types of duties are important to them. As such, external giving is an important part of the giving among Christians. 
This line of inner logic over external giving provides us with a clue to understand a piece of interesting finding: Christian charitable groups might not be particularly preferred by our informants when deciding their donation and volunteering. Scholars working on the domain of social identity have studied and generally supported the idea of in-group favouritism (e.g., Tajfel and Turner 1986). On the field of religious and secular giving, Wuthnow (1999) contends that religious exclusiveness encourages people to volunteer for their own religious groups; and such motivation might not extend to a broader context. Schnable (2014) also concludes that aid-organizations with religious background enjoy the advantage in raising funds from people of their corresponding religious faith. Sargeant and Shang (2017, p. 96) suggest that charity with 'Christian' label could bring a higher level of confidence to Christian donors because of perceived better management. Yet, some scholars cautiously remind us that in-group favouritism on giving is not always held in practice. In her writing on welfare and sectarianism in Lebanon, Cammett (2014) observes that sometimes sectarian faith groups make a deliberate attempt to distribute welfare goods to members of out-groups. She identifies factors such as the selection of political strategy and the degree of intrasect competition to account for the likelihood of a sectarian group to engage actively in welfare provision to out-group members. Our findings also show a complicated picture on how in-group favouritism influences the informants' decisions on external giving. On the one hand, supports for the Christian-preference are detected. Many informants gave a positive evaluation on 'Christian charity' as they view Christian groups to be more trustworthy. One informant, Claudia, commented that as these Christian run groups are under sacred monitoring and hence would do their best as they see their actions to be accountable to God. This sense of 'sacred monitoring' and doing the religious duty assures her of her choice in supporting these groups.

On the other hand, some informants remarked that the Christian identity of the charitable groups might not be extremely appealing to them. To some informants, the ultimate decision over the selection of the organization is the management and effectiveness of the charitable organizations in using the resources to serve their charitable cause. Paul's critical remark serves as a nice illustration.

"In principle, we express our faith in every aspect of human life. Donation and volunteering could also be one aspect. However, we cannot say that donation and volunteering is the only path we need to take in expressing our faith....... Sometimes, we humans tend to pay unnatural and unnecessary effort to manifest our faith in our life. When I donate, I will not concern whether the organization is a Christian group or not. Even if it is a Christian group working on evangelical mission and spreading Gospel, it will not be appealing to me. Unless the specific target group or community I am eager to donate is only run by a Christian group, I will not have a preference donating to a Christian group. When I donate, I only consider with money-how well the group manages the money, how well it spends the money on the needy. Christian groups are not necessarily good at doing this. They might get into different kinds of troubles. They might perform badly financially. Eventually, it is really 'money'. We will judge from the angle of money to determine where we donate the money. Faith is not the criterion when we make donation. If it is about faith, then we can just give the money to the church."

Joseph also noted from his own volunteering experience that, in some scenarios, Christian groups might not be very effective in providing the services. He is a leader of a singing volunteering team, which often receives invitations from different organizations to hold singing performances. He finds it quite challenging to work with Christian groups. He said,

"Of course, it is good if we can serve these Christian groups. But it is extremely hard ... ... (He then sighed.) There is one thing: the songs we sing (popular songs or Cantonese opera) do not fit Christian groups. 'Oh, these songs are not good. Better to sing hymns!' They probably say. ... ... It is not us who don't want to sing the hymns, but then many non-believers (audience) actually don't know what you are singing!" 
Beyond the concern that Christian groups might not be competent in providing effective services and aid to the needy, one informant, Phoebe, added that she deliberately donates money to non-Christian secular groups. Her rationale, paradoxically, has to do with her Christian faith and mission.

"I deliberately pick non-Christian groups to give. I expect myself to respond to God, and when I take part in donation or volunteering, I intend to spread the Gospel and God's love outward. Of course, the organizations do not know I am a Christian. But I have such expectation. ... ... Perhaps it is more visible in volunteering: when you do it sincerely, seeking to bring God's love to others, the people can see and feel it. Just like what Jesus teaches, we need to do things on others, so that they know we are Jesus' followers. In this way, Gospel is spread out. ... . . . Perhaps people looking at my donation do not know that I am spreading the Gospel, but at least God knows I am doing so. After I do my part, God has His methods to let himself visible to those people."

The above finding that Christian charitable groups might not always be preferred by our informants actually runs parallel to the previous discussion on the making of Christian selves through external giving. The essence of the Christian self is not so much about following Christian teaching commands at face value or embracing Christian labels in name. Rather, it is the inner transformation of the selves, taking up and enacting the spiritual qualities, that counts. Recapping a sentence said by informant Aaron earlier, "God gives us talent to spend the money wisely to assist the needy." In doing external giving, individual believers utilize and activate God's gifted talent, using it in a 'wise' way to benefit the needy. In this case, external giving embodies secular reflexivity within an expanded space that allows Christians to live out their sacred selves with different practical and rational calculation and consideration. It is this integration of divine duty and secular duty as demonstrated in the act of giving that transforms the individual Christian into a Christian sacred self.

\section{Analysis and Concluding Remarks}

In this paper, we have presented a case study of the Hong Kong Christians' subjective understanding and practices on external giving and the complexity that surrounds this act of external giving. From a scholarly viewpoint, this paper hopes that the findings from our specific case study of a Hong Kong Christian community will enrich our understanding on the subject matter of Christian giving, specifically external giving.

One key idea highlighted is the act of giving, which constitutes a central part of the religious life for individual believers that enables them to live out their faith and become truly Christians. In the existing scholarship on the subject, scholars generally adopt a rational choice analysis on giving (Lincoln et al. 2008), seeing it as a rational and economic transaction undertaken by believers in exchange for expected returns (Hoge 1995, p. 56), such as afterlife-utility as well as personal fame and social reputation in this material world. Without rejecting this line of arguments, the data from this study inform us of another important perspective to religious (Christian) giving. We argue that giving should not simply be understood as a rational decision made by Christians to fulfil their religious duties or pursue external rewards. Giving should be viewed as a dynamic and transformative act. Through giving, individual believers reflect upon and enact their sacred selves. In this sense, giving can be seen as, in Foucauldian language, a 'technology of the self' applied by Christians to engage in their self-making project. They are not compelled by any religious authority to do the giving, but, with their internalization and understanding of Christian morality, they actively take up giving as a technology to activate and transform their selves. Along this line of argument, then, the question to be pondered is not directly concerning whether or not individual believers make a giving, or what the determinants of giving are. Instead, we need to explore how the self is transformed through giving and, correspondingly, how the practice of giving is shaped within this process of self-transformation.

There are two important aspects of the self-transformation process. On the one hand, in doing giving, Christians align their selves with God. At a discourse or an ideal level, they acknowledge 
that giving is not simply about expressing and utilizing one's own effort and wisdom to do goodness. Although we highlight that there is a relatively lesser degree of spiritualization on external giving when compared to church giving, they also attach transcendental meaning on their external giving, viewing their actions as tantamount to the work of Jesus Christ as Christ's love to the needy. Likewise, they viewed their actions as making good use of the talent given by God, hence their response to God's grace. In the playing out of the sacred self, they viewed themselves and the recipients of their giving as of equal standing. In this sense, they attempt to transcend the material superiority and class hierarchy between themselves and the recipients. They see giving as a divine duty to God and the recipients as participants who offer them a chance to perform God's calling to do goods to others, hence fulfilling their inner spiritualism.

From a broader perspective, Christian giving not only contribute to the making of individual sacred selves, importantly, it also contributes to the construction of a sacred moral economy with God, Christian givers and the recipients of the giving as three key players in a tripartite relationship. In his book Ritual and its Consequences, Seligman (2008) argues that religion and rituals contribute to the making of 'make-believe' or a subjunctive world. Their discussion hints to how non-human agents like God take part in the believers' subjunctive world and shape their concrete actions, which bring real consequences on their social world. Although God may not be seen as a concrete social actor, we can see how, from the believers' point of view, God is imagined as an actor they try to respond and emulate through their giving to real human subjects of the needy recipients. In other words, the symbolic connection between God and believers is channelled by the concrete flow of giving between believers and the recipients.

Within the matrix of the moral economy, the social relationship between different actors is not so much governed by economic forces, but more by moral norms and expectations (Booth 1994), which could transcend the economic reality. This could be seen in the way Christians relate themselves with the recipients in external giving. In principle, Christian givers highlight the moral and spiritual equality between them and the recipients of their giving, as they are all children of God. Moreover, instead of seeing the recipients having a material need for receiving the giving, arguably it is the Christian givers who have a greater spiritual need to do giving. More scholarly endeavours could be made to reflect upon the conceptualization of 'needs' in future research on Christian giving, as well as on the broader issue of religious giving.

One final point to note concerns the significance of Christian morality and Christian ethic in motivating and guiding believers to engage in giving and doing it in a Christian way. Under Christian ethic, giving is not seen and enacted as a self-fulfilment of the ego, but a realization that one's self is part of God's moral order and is under constant divine moulding and guidance. At the same time, individual Christians also make their giving decision based on deep-rooted values such as economic rationality and effectiveness maximization of our modern secular world. Their selection choice of the charity organisations is a rational choice decision where trust, organisational effectiveness, and integrity are important characteristics that feature in their decision-making and acts of giving. It is thus possible to argue that there are two forces at work here, that of Christian ethics and secular ethics, with each playing complementary and supplementary roles to the other. This organic integration of sacred act of giving with secular considerations prompts us to reflect upon the Durkheimian tradition in seeing sacred-profane division as an essence to religious lives. In his review and discussion on the concept of secularization, Casanova (2006) remarks that "the religious and the secular are inextricably bound together and mutually condition each other" (p. 10). In our case study, we see a dynamic interplay between the sacred and the secular forces surrounding external giving. In this way, we see a 'sacralization of the secular' and at the same time 'secularization of the sacred'.

Finally, in the modern era, many reflexive believers of different religions do not just confine their expressions and practices of religiosity within the sacred places and institutions. Their faith is expressed and practiced on different occasions in everyday lives. From Max Weber's (1992) discussion on inner-worldly asceticism, to the more contemporary discussion on everyday religion (Ammerman 
2007), scholars have long paid attention to how religious followers express and practice their faith in everyday secular life. Thus, in interrogating Christian giving, it is imperative that we explore giving at church and outside of it. It is through interrogating and understanding the multifaceted and multi-layered expressions and meanings that the individual Christians adhered to and embraced in their act of giving that we could fully comprehend the quest for enacting their divine and secular duty as they seek to follow the Christian logic of giving and transform their mundane secular self into the sacred self.

Author Contributions: S.W.L.C. contributes to the data collection and the writing (original draft preparation). K.E.K. contributes to the theoretical conceptualization and framework, supervision and the editing of the paper.

Funding: This research received no external funding.

Acknowledgments: We are grateful to all our informants who have shared their insights and perspectives on Christian giving with us. Furthermore, we are very thankful to the two anonymous reviewers for their inspiring comments and helpful suggestions.

Conflicts of Interest: The authors declare no conflict of interest.

\section{References}

Ammerman, Nancy T. 2007. Introduction: Observing modern religious lives. In Everyday Religion: Observing Modern Religious Lives. Edited by Nancy T. Ammerman. New York: Oxford University Press, pp. 3-18.

Becker, Penny Edgell, and Pawan H. Dhingra. 2001. Religious Involvement and Volunteering: Implications for Civil Society. Sociology of Religion 62: 315-35. [CrossRef]

Bekkers, René, and Theo Schuyt. 2008. 'And who is your neighbor?' Explaining denominational differences in charitable giving and volunteering in the Netherlands. Review of Religious Research 50: 74-96.

Bekkers, René, and Pamala Wiepking. 2011. Who Gives? A Literature Review of Predictors of Charitable Giving Part One: Religion, Education, Age and Socialisation. Voluntary Sector Review 2: 337-65. [CrossRef]

Booth, William. 1994. On the Idea of the Moral Economy. The American Political Science Review 88: 653-67. [CrossRef]

Cammett, Melani Claire. 2014. Compassionate Communalism: Welfare and Sectarianism in Lebanon. Ithaca: Cornell University Press.

Campbell, David E., and Steven J. Yonish. 2003. Religion and volunteering in America. In Religion as Social Capital: Producing the Common Good. Edited by Corwin E. Smidt. Waco: Baylor University Press, pp. 87-106.

Casanova, José. 2006. Rethinking Secularization: A Global Comparative Perspective. The Hedgehog Review 8: 7-23. [CrossRef]

Chan, Alan, and Shu-Kam Lee. 2016. Determinants of Religious and Secular Donations in Canada. Interdisciplinary Journal of Research on Religion 12: 1-15.

Chang, Wen-Chun. 2005. Religious Giving, Non-religious Giving, and After-life Consumption. The B.E. Journal of Economic Analysis \& Policy 5. [CrossRef]

Cheung, Wai Lung. 2019. 'Your Kingdom Come': A Case Study on Christian Giving. Ph.D. dissertation, University of Hong Kong, Hong Kong, China.

Clain, Suzanne Heller, and Charles E. Zech. 1999. A Household Production Analysis of Religious and Charitable Activity. American Journal of Economics and Sociology 58: 923-46. [CrossRef]

Eckel, Catherine C., and Philip J. Grossman. 2004. Giving to Secular Causes by the Religious and Nonreligious: An Experimental Test of the Responsiveness of Giving to Subsidies. Nonprofit and Voluntary Sector Quarterly 33: 271-89. [CrossRef]

Forbes, Kevin F., and Ernest M. Zampelli. 2013. The Impacts of Religion, Political Ideology, and Social Capital on Religious and Secular Giving: Evidence from the 2006 Social Capital Community Survey. Applied Economics 45: 2481-90. [CrossRef]

Foucault, Michel. 1988. Technologies of the Self. In Technologies of the Self: A Seminar with Michel Foucault. Edited by Luther H. Martin, Huck Gutman and Patrick H. Hutton. Amherst: University of Massachusetts Press, pp. $16-49$.

Foucault, Michel. 1990. The Use of Pleasure: Volume 2 of the History of Sexuality. Translated by Robert Hurley. New York: Vintage Books. 
Heim, Maria. 2004. Theories of the Gift in South Asia Hindu, Buddhist, and Jain Reflections on Dāna. New York: Routledge.

Helms, Sara, and Jeremy P. Thornton. 2012. The Influence of Religiosity on Charitable Behavior: A COPPS Investigation. The Journal of Socio-Economics 41: 373-83. [CrossRef]

Hill, Jonathan P., and Brandon Vaidyanathan. 2011. Substitution or Symbiosis? Assessing the Relationship between Religious and Secular Giving. Social Forces 90: 157-80. [CrossRef]

Hodgkinson, Virginia Ann, Murray S. Weitzman, Stephen M. Noga, Heather A. Gorski, and Arthur D. Kirsch. 1996. Giving and Volunteering in the United States: Findings from a National Survey. Washington: Independent Sector.

Hoge, Dean. 1995. Explanations for Current Levels of Religious Giving. In Cultures of Giving: How Region and Religion Influence Philanthropy. Edited by Charles H. Hamilton and Warren F. Ilchman. San Francisco: Jossey-Bass, pp. 51-70.

Huang, C. Julia. 2009. Charisma and Compassion: Cheng Yen and the Buddhist Tzu Chi Movement. Cambridge: Harvard University Press.

Jackson, Elton F., Mark D. Bachmeier, James R. Wood, and Elizabeth A. Craft. 1995. Volunteering and Charitable Giving: Do Religious and Associational Ties Promote Helping Behavior? Nonprofit and Voluntary Sector Quarterly 24: 59-78. [CrossRef]

Kitchen, Harry. 1992. Determinants of Charitable Donations in Canada: A Comparison over Time. Applied Economics 24: 709-13. [CrossRef]

Kuah, Khun Eng. 2015. Engendering Religious Compassion. Asian Journal of Social Science 43: 357-75. [CrossRef]

Lincoln, Ryan, Christopher A. Morrissey, and Peter Mundey. 2008. Religious giving: A literature review. Science of Generosity, 1-47. Available online: https:/generosityresearch.nd.edu/assets/20447/religious_giving_final.pdf (accessed on 2 July 2019).

Lyons, Mark, and Ian Nivison-Smith. 2006. Religion and Giving in Australia. Australian Journal of Social Issues 41: 419-36. [CrossRef]

McCarthy, Susan K. 2013. Serving Society, Repurposing the State: Religious Charity and Resistance in China. The China Journal 70: 48-72. [CrossRef]

Nemeth, Roger J., and Donald A. Luidens. 2003. The Religious Basis of Charitable Giving in America. In Religion as Social Capital: Producing the Common Good. Edited by Corwin E. Smidt. Waco: Baylor University Press, pp. 107-20.

O’Neill, Mark. 2010. Tzu Chi: Serving with Compassion. Singapore: John Wiley \& Sons (Asia) Pte.

Palmer, David A., and Elijah Siegler. 2017. Dream Trippers: Global Daoism and the Predicament of Modern Spirituality. Chicago: University of Chicago Press.

Putnam, Robert D. 2000. Bowling Alone: The Collapse and Revival of American Community. New York: Simon \& Schuster.

Queen, Edward L. 1996. The Religious Roots of Philanthropy in the West: Judaism, Christianity and Islam. Indianapolis: Indiana University, Center on Philanthropy.

Quiggle, James D. 2009. Why Christians Should Not Tithe: A History of Tithing and a Biblical Paradigm for Christian Giving. Eugene: Wipf \& Stock.

Ruiter, Stijn, and Nan Dirk De Graaf. 2006. National Context, Religiosity, and Volunteering: Results from 53 Countries. American Sociological Review 71: 191-210. [CrossRef]

Sablosky, Roy. 2014. Does Religion Foster Generosity? The Social Science Journal 51: 545-55. [CrossRef]

Sargeant, Adrian, and Jen Shang. 2017. Fundraising Principles and Practice. Hoboken: Wiley.

Schnable, Allison. 2014. Religion and Giving for International Aid: Evidence from a Survey of U.S. Church Members. Sociology of Religion 76: 72-94. [CrossRef]

Seligman, Adam B. 2008. Ritual and Its Consequences: An Essay on the Limits of Sincerity. Oxford: Oxford University Press.

Son, Joonmo, and John Wilson. 2012. Using Normative Theory to Explain the Effect of Religion and Education on Volunteering. Sociological Perspectives 55: 473-99. [CrossRef]

Tajfel, Henri, and John C. Turner. 1986. The Social Identity Theory of Intergroup Behavior. In Psychology of Intergroup Relations. Edited by William G. Austin and Stephen Worchel. Chicago: Nelson-Hall Publishers, pp. 7-24.

Terazawa, Shigenori. 2015. Multi-Dimensional Religiosity and Volunteering in Contemporary Taiwan. Asian Journal of Social Science 43: 466-87. [CrossRef] 
Van Tienen, Marike, Peer Scheepers, Jan Reitsma, and Hans Schilderman. 2011. The Role of Religiosity for Formal and Informal Volunteering in the Netherlands. VOLUNTAS: International Journal of Voluntary and Nonprofit Organizations 22: 365-89. [CrossRef]

Weber, Max. 1992. The Protestant Ethic and The Spirit of Capitalism. Translated by Talcott Parson. London: Routledge. Wilson, John, and Thomas Janoski. 1995. The Contribution of Religion to Volunteer Work. Sociology of Religion 56: 137-52. [CrossRef]

Wuthnow, Robert. 1991. Acts of Compassion: Caring for Others and Helping Ourselves. Princeton: Princeton University Press.

Wuthnow, Robert. 1999. Mobilizing Civic Engagement: The Changing Impact of Religious Involvement. In Civic Engagement in American Democracy. Edited by Theda Skocpol and Morris P. Fiorina. New York: Brookings Institution Press, pp. 331-63.

Yao, Yushuang. 2012. Taiwan's Tzu Chi as Engaged Buddhism: Origins, Organization, Appeal and Social Impact. Leiden: Global Oriental.

Yeung, Jerf W. K. 2018. Are Religious People Really More Helpful? Public and Private Religiosity and Volunteering Participation. Nonprofit and Voluntary Sector Quarterly 47: 1178-200. [CrossRef]

(C) 2019 by the authors. Licensee MDPI, Basel, Switzerland. This article is an open access article distributed under the terms and conditions of the Creative Commons Attribution (CC BY) license (http://creativecommons.org/licenses/by/4.0/). 



\title{
Article \\ "Serving the Lord": Christianity, Work, and Social Engagement in China
}

\author{
Francis K. G. Lim \\ School of Social Sciences, Nanyang Technological University, 48 Nanyang Avenue, Singapore 639818, Singapore; \\ fkglim@ntu.edu.sg
}

Received: 13 February 2019; Accepted: 12 March 2019; Published: 14 March 2019

\begin{abstract}
This study examines how Chinese evangelical Protestant employees view work and the workplace, through the lens of their religion, and how they seek to influence the broader society, in a highly restrictive religious domain in China. Using the concept of everyday religion, I examined how these employees seek to integrate faith into their work and the workplace, and the issues and challenges they face in the process. While existing China-focused studies have mainly looked at the experience of the business elite and Christian bosses, I inquired into the experience of the employees, specifically the professional class. It was found that they did not see a clear boundary between the 'religious' and the 'secular' in the workplace. At the same time, they discursively constructed a distinction between their own Christian work ethos and that of their non-Christian colleagues. This discursive self-othering was double-edged. While it enabled the Christian employees to construct a distinctive workplace and social identity, it risked resulting in them being perceived negatively by non-Christian colleagues, as belonging to a "different kind" (linglei), thus, accentuating the social gulf and tension that might have already existed between the Christian and the non-Christian employees. Most regard the workplace as an important arena for the concrete expressions of their Christian faith and values in everyday life. In doing so, they seek a moral transformation of the workplace, as a way to transform the wider society. I argue that their effort to influence their colleagues and transform the workplace culture is an important kind of unobtrusive social engagement, without open mobilization in civil society.
\end{abstract}

Keywords: China; Christianity; spirituality; work; workplace; social engagement

\section{Introduction}

\section{"People Will See How You Walk Before They Believe What You Talk"}

The above comment was made by Andy, an engineer working in a software company in Shenzhen, the economic powerhouse in Southern China. When Andy lost his job in the United States, he had the opportunity to relocate to China to work in a foreign software company. This also offered Andy a chance to evangelize in his country of origin. "And that's why I realized that the Lord has prepared me all these years, for me to go back to China", Andy said, during our interview in a Christian theological college in Singapore, where he was studying. "It was over the years that I began to see how God had actually prepared me for Shenzhen, because it is right next to Hong Kong, so I would go to Hong Kong to do bible study". Andy's experience reveals how important the workplace is for evangelism, among Chinese Christians. Many strive to be role models for the faith in their respective workplaces, as they interact with non-Christian colleagues and engage in workplace evangelism. At the same time, Chinese Christians like Andy, are constantly negotiating the institutionally imposed boundaries that separate religion from other social domains, and face challenges in expressing their faith in the workplace. While the rapid rise of Christianity in China, over the past two decades, has prompted many research into various aspects related to the phenomenon, comparatively fewer studies have 
been conducted on how Chinese Christian employees view their work and workplace, the impact of religion on their relationship with non-Christian colleagues, and the challenges of integrating faith into the work domain.

The economic reforms over the last four decades in China have unleashed a torrent of market forces in China. This has resulted in the phenomenal rise in the standards of living for many of the country's citizens. At the same time, new social problems and fault lines have emerged, such as rising income inequality, heightening social tensions, environmental degradation, rampant official corruption, forced expropriation of farmers' land, and mounting cases of food safety violations. Concerns over the state of the citizens' moral well-being had surfaced, even in the early days of the "reform era", with commentators asking whether the unleashing of the market forces in society, had negatively impacted on social relations and morality (e.g., Ci 2009; Hanafin 2002; Osburg 2013). Relatedly, the questions of, if and how, religion can contribute to the 'moral reconstruction' (daode zaijianshe) of contemporary China, has preoccupied many ordinary citizens, scholars, policymakers, and religious leaders, in recent years (Shue 2011; Liang 2014; Yan 2014; Fisher 2017). Over the years, a number of scholars have reflected and written on how Christianity might provide solutions to some of the pressing social and moral issues in contemporary China. These scholars include those who do not formally embrace the faith in confessional terms, but are nevertheless immensely concerned over Christianity's role in shaping China's future. Prominent among this group of "culture Christians" is He Guanghu, who draws on the work of Paul Tillich and John Hick for his writings, and is also a vocal public intellectual, who has demanded the Chinese government to show greater tolerance of human rights. Since the late 1990s, a group of public intellectuals have emerged for whom Christianity is both a personal faith and a source of their political ideals. Christian intellectuals, such as Wang Yi and Yu Jie, are prominent human rights activists, whose activities have been met with harsh responses from the authoritarian party-state. Others have looked to Calvinism for inspiration to engage with the state and society, by formulating a theology of constructive dialogue (Chow 2018, pp. 20-21).

On the Protestant theological front, Yang (2010, pp. 197-98) has argued that, for Christianity to establish itself even more firmly in the Chinese culture, a Chinese Christian theology has to be developed, based on the empirical work that details the Christian communities' contemporary interpretation of their faith. To this end, some leaders and theologians in the official Three-Self Patriotic Movement have reflected critically about the role of the church in a rapidly changing society fraught with tensions and faced with huge challenges. Some have proposed a "Theological Reconstruction" to enable the Christian church to maintain its relevance in society, through greater social awareness and engagement (Wang 2001; Wickeri 2007). In recent years, however, with the influx of intellectuals, highly educated professionals and city dwellers, the dominant Protestant evangelical tradition of religious piety and aversion to politics and social engagement has given way to a more variegated position toward social awareness and political activism (Yao 2011, p. 67). For example, some Christians have embraced human rights activism and regard the quest for social justice, religious freedom, and political reform, as integral to the practice of the Christian faith. Others have established strong connections with overseas churches and human rights organizations which share the same social and political agenda, and have often acted as spokespersons of China's house churches, in the international media (Yao 2011, pp. 67-68). On the other hand, some prominent political activists who have converted to Protestantism show a diminution of prior political activism. Being evangelical and fundamental in their beliefs, these former political activists have become more focused on proselytizing and on saving souls, and are much less concerned with calling for democratic political change (Wright and Zimmerman-Liu 2013). However, the majority of the house church congregations tend to take the middle approach of being more engaged in social issues, while refraining from political activism and direct confrontation with the party-state. Wielander (2009) has examined the activities of Christian intellectuals in house churches and their implications for China's democratization process. She finds that Christian public intellectuals, through their activities, could potentially serve as 'bridges' between theory and practice, rural and 
urban divide, social class divisions, as well as China and the world. This would, in turn, contribute to a broader civil society activism that seeks deeper democratization in China.

In contrast to the above cited research that mostly focuses on Christian activism in civil society, in this paper, I explored how Chinese evangelical Protestant employees view work and the workplace through the lens of their religion, and how they seek to influence the broader society, in a highly restrictive religious domain in China. The respondents in this study wished to address the perceived moral problems prevalent in the society, through efforts to transform the workplace and their non-Christian colleagues. This paper is based on a larger research on Christian social engagement in contemporary China. In this project, my collaborator, Sng Bee Bee, and I conducted in-depth, semi-structured interviews, between 2013 and 2016, with 38, mainly evangelical Protestant professionals, from mainland China. There were 23 female and 15 male respondents, aged between 24 to 47 , comprising teachers, managers, engineers, business executives, and medical workers. Two focus groups interviews were conducted in Kunming ( 5 women and 4 men) and Wenzhou ( 2 women and 2 men). All respondents were recruited through a snowball sampling, via our pre-existing contacts among the Christian congregations in Chengdu, Kunming, Wenzhou, Shanghai, and Singapore. Questions asked in the semi-structured interviews inquired into whether religion is a private affair; if it should be separated from the social and political domains; and if it has shaped employees' view of work and work practices. Respondents were also probed on their views of Christian and non-Christian colleagues, and if there was anything in society that needed to be improved or changed. Another set of questions examined their use of the Internet and social networking sites, such as how important these communication tools were in their personal, religious, and work life, and what were the limitations and problems encountered in their usage.

Conceptually, I regard the practice of Christianity in China as a form of 'everyday' or 'lived' religion (McGuire 2008; Schielke and Debevec 2012; Ammerman 2007). This perspective looks at how religious practitioners express their faith and pursue religious activities in their everyday life. They do so without paying much attention to institutionally defined religious dogmas and orthodoxy. Some scholars have argued that for many religious practitioners, there are no sharp divisions between religion, public, and private lives (e.g., Cochran [1990] 2014; Hall 1997; Woodhead 2013). In their everyday practice of religion, people might ignore institutionally constructed boundaries that separate social life into different domains. The focus on everyday religion is a recognition of the embeddedness of religious actors in culture, and these actors are, at the same time, co-creators of the same culture.

Overwhelmingly, this study found that Christian employees did not see a clear boundary between the 'religious' and the 'secular', in the workplace. At the same time, they discursively constructed a distinction between their own Christian work ethos and that of their non-Christian colleagues. Most regarded the workplace to be an important arena for the concrete expressions of their Christian faith and values in everyday life. In doing so, they sought a moral transformation of the workplace, as a way to transform the wider society, with Christian values. In this regard, I argue that these Christians were engaging in a kind of religious social engagement. By religious social engagement, I mean the efforts by religious individuals and groups engaging with social issues and seeking to readdress these issues, by engaging in activities that might or might not involve widespread, coordinated mobilization efforts. In recent years there has been a growing scholarly attention on religious social engagement, through charity and philanthropy in China (e.g., McCarthy 2013; Liang 2014; Wu 2016; Weller et al. 2017). Such studies focused on the activities of formal religious organizations, in the civil society, and their interactions with the state. For example, pastors of some unregistered Pentecostal and charismatic churches exhort and encourage members to participate in patriotic prayers, public relations, and charitable and social work programs (Koesel 2014). This study suggests looking beyond the common approaches of examining religious organizations' philanthropic and charitable activities, and their mobilization in civil society. Some of these activities might be conducted in ways that are non-obtrusive and non-antagonistic in their interactions with controlling state institutions (e.g., Klandermans 1988; Katzenstein 1990). I would argue that by examining this kind of activities as social 
engagement in everyday Christianity, in this case, in the workplace, we are able to better understand how Christianity can continue to experience a rapid growth in China, in the context of the deepening political authoritarianism, curtailment of an emerging civil society, and a tighter surveillance and control of Christianity by the Chinese authorities. By discursively construing work as service, Chinese evangelical Protestants seek to change what they regard as unethical behavior in the workplace, with the broader aim of addressing the perceived moral malaise inflicting the society at large.

\section{Spirituality and Religion in the Workplace: An Overview}

In the sociological literature, the relationship between religion, spirituality, and work was famously analyzed by Max Weber in his Protestant Ethic and the Spirit of Capitalism. As is well-known, Weber starts with a discussion of Luther's interpretation of the notion of vocation, or "calling" (beruf), as entailing a spiritualization of worldly activity (Frey 2008). Luther's interpretation of the calling, directly led to the Calvinist notion of inner-worldly asceticism, the key religious orientation that Weber identifies as the basis of the "spirit of capitalism". Contemporary advocacy on spirituality and religion in the workplace (SRW) can at least be traced to the Faith at Work movement that had first emerged in late 19th century, in Europe and the United states. Then, an increasing number of Christians tried to foster a closer integration of faith and work, in order to ensure that religion remained relevant in addressing the issues of the workplace and the wider society. Miller's (2007) historical study of the Faith at Work movement highlighted the influential role played by the Protestant clergyman, Walter Rauschenbusch, in articulating a social gospel and exhorting Christians to participate actively in, and to transform, the business domain. Rauschenbusch's key message was that through a transformation of the self, business, and the workplace, religion could continue to be a potent force in a rapidly secularizing society. The movement contributed to the rise of post-World War II Protestant ecumenical activity that emphasized the ministry of the laity, especially in their respective occupations. The insecurity, constant change, and intense pressure associated with many modern secular occupations, have ironically stimulated a quest among many workers to turn to spirituality and religion, to find meaning in their lives (Miller 2007).

In the Catholic Church, Pope Leo XIII in 1891 issued the encyclical, Rerum Novarum (The Condition of Labor), urging a closer assimilation of religious values and actions, in all aspects of a Christian's life, including the work life. The Second Vatican Council (1962-1965), again, stressed the importance of the laity, in supporting the Church's evangelical mission, through the workplace. Many Christians have indeed aspired to adopt a 'holistic' approach in practicing their religion by rejecting the notion that spirituality and religion should be confined to one's 'private' domain and not be entangled with one's occupation. Popular books on business leadership and management, such as Bruce Barton's The Man Nobody Knows, advocated taking Jesus as a role model for business leaders. Rick Warren's The Purpose Driven Life is a good example of how Christian writers continue to advocate making religion directly relevant to everyday life and work, and how many lay Christians believe this to be immensely important to live a meaningful and fulfilling life.

Some past SRW research have looked at the creation of a favorable work culture and business leadership. For example, some research has shown that the cultivation of spirituality in organizations might enhance employees' well-being, instill positive attitude toward work, and create a more amiable workplace (Mitroff and Denton 1999; González-González 2018). Employees' spiritual well-being is found to have positive impacts on their morale, ability to cope with stress, motivation levels, and productivity at the workplace (Benefiel 2005; Sass 2000; Duchon and Plowman 2005; Fry et al. 2010; Chen and Yang 2012). In Sri Lanka, a study finds that when business leaders embrace spirituality in the workplace, they also strive towards self-actualization and are more concerned with ethical decision making (Fernando 2002). In view of the potential benefits of workers' integrating religion, spirituality, and work, Hicks (2003) argues that business leaders should create a pluralistic and supportive environment for employees to achieve faith integration at the workplace. 
Some scholars adopting a more critical approach have highlighted instances of 'symbolic violence' being perpetuated on employees by the senior management, in the latter's effort towards integrating faith in the workplace. Drawing on Bourdieu's critical sociology, Kamoche (2012) argues that the top-down imposition of organizational spirituality is a new way for firms to manage and discipline their employees. In Malaysia, for example, the country's push to develop products for its Islamic economy, has resulted in the adoption of sharia (Islamic legal codes) by some companies, to shape their workplace culture (Sloane-White 2011). Executives in these firms seek to develop 'personnel sharia' that that govern employees' ethical values and moral principles, as well as 'corporate sharia', based on the Quran and the Hadith, for commercial and managerial activities. In such Islamic workplaces, piety and Islamic subjectivities are not just solely a matter of individual choice, but are also shaped, monitored, and enforced by a sharia-rized corporate culture. Other studies have investigated the relationship between the expression of religious identity and the risk for perceiving or experiencing discrimination at the workplace. For example, studies have overwhelmingly shown that Muslims and Jews are more likely to perceive discrimination at the workplace in the US and the UK, whether or not the issues of religion ever emerge at the workplace (Scheitle and Ecklund 2017; Ghumman and Jackson 2010; Mythen et al. 2009). This has prompted some believers, especially Muslims, to deemphasize or hide their religious identity, either at the workplace, or when seeking employment. Thus, while research has uncovered some benefits of incorporating religion and spirituality into the workplace culture, other studies have also shown that expressions of religiosity and spirituality could often lead to stigmatization, conflict, tension, distraction, and discrimination in the workplace (Gregory 2011).

Most studies on religion in the workplace are conducted in countries where governments are relatively tolerant of religion, and not in places where religion is tightly regulated, such as in China, former Soviet Union, and Vietnam (Tam and Quijada 2015). Thus, while some researchers have argued that businesses should promote a better integration of religion, spirituality, and work, this measure is difficult or even impossible to be implemented in certain countries with strict secularist policies (e.g., France) or with governments that are ideologically atheistic (e.g., in Communist party-states). Although China's constitution allows for religious freedom, religion in China is not a "private" affair' - not in the liberal sense that, citizens have the freedom to engage in religious affairs free from state monitoring and coercion. The Chinese party-state, through its religious policies, has always sought to control and manage religion, with strict regulations on where religious practices might be conducted (Leung 2005; Laliberté 2011). In China, it is illegal for citizens to practice religion in the workplace. One of the aims of this paper is, hence, to examine how believers view work, and the possibility of bringing their religious faith to the workplace, where it might be a part of the religious 'gray market' (Yang 2006).

Scholars who have studied religion and work in China, mostly focused on the business elite or the Christian entrepreneurs. One earlier study examined how China's entry into the World Trade Organization has provided opportunities for the Chinese Christian entrepreneurs to exert their influence in both economic and spiritual affairs in China (Chan and Yamamori 2002). In recent years, many so-called 'Boss Christians' in Wenzhou also strived to shape the Chinese nation in both material and spiritual terms (Cao 2013). They hoped to exert a moral influence on society by letting Christian values guide their business activities, interpersonal relationships, and philanthropic projects, in effect, melding a form of elite Christianity with ideals of spiritual nationalism. Lee et al. (2012) found that conducting business in China has a negative impact on ethics among some Chinese Christian business leaders. Meanwhile, for the business leaders, a Christian corporate culture is highly conducive for sustaining Christian witness. In a study by Tong (2012) on overseas Chinese Christian businesspeople in Shanghai, personal piety was found serve as the foundation of business ethics and guide their dealings with Chinese officials, clients, business partners, and ordinary workers. In their study on trust among Protestant entrepreneurs, Tong and Yang (2016) found that Chinese Protestant entrepreneurs wanted to be more trustworthy and to be more trustful of others, after becoming Christians, and some of them thought that a major religion like Christianity would lead to better moral behavior. 
The representative studies cited above, thus, underscored the importance of gaining in-depth understanding on how religion impacts the meaning of work, workplace behavior, and work ethics. In broad terms, therefore, this study examined how Chinese evangelical Protestants sought to integrate their faith in the workplace. In this paper, faith integration refers "to the attempt of Christians in the workplace to think, feel, and act in ways that reflect their identities in Christ" (Stansbury 2015, p. 23). With research on religion (especially Christianity), and work in China, mostly being focused on the business elite, this paper focuses on the experience of the Chinese Christian employees, who are in workplaces that were mostly established by non-Christians. In this paper, while my analytic focus is on the individual level, the analysis is contextualized in the relevant organizational and societal contexts. I examined the meaning that evangelical Protestant workers attribute to their work, from the viewpoint of religion, and how as individuals they seek to express their faith in environments that often prohibit the overt practice of religion or are even hostile to it. The question of how Christians belonging to the professional class view work and express their religiosity in the workplace deserves serious study, as the class as a whole, are economically, politically, and culturally influential in contemporary China. This is also the social class for which work or occupation is a crucial defining element of its members' personal and social identities (Bourdieu 1987; Lamont 1992; Bottero 2004). The findings of this research on believers' attitude towards their work and colleagues, and how they seek to influence the wider society, will thus, contribute to the scholarship on religion and social change in China.

\section{Being Christians in the Workplace: Employees of a "Different Kind"}

According to one estimate, Christians (both Protestants and Catholics) comprise around 5\% of China's population (Pew Research Center 2012). With Christianity as a minority religion, this would mean that, unless they work in Christian organizations, most Chinese Christians are likely to work in an environment where most of their colleagues are non-Christians. This also means that the Christian employees' endeavor to integrate faith and work can potentially be fraught with tension and challenges. This is partly due to their small numbers, and partly because of a strong sense among Christian workers that their religious values distinguish them from the non-Christians. This is reflected in the experience of Linda from Wenzhou, currently enrolled in an independent seminary:

After graduation, I did an internship as a customer service officer at a hotel. My job was to serve patrons, and how I mix my faith with my job is that I make sure that at the very least, my service attitude on the surface must be thoughtful and attentive. Often, there are people who use underhand means behind customers' backs. For instance, if a customer was being rude, the waiter might be revengeful and add stuff into the customer's food before serving. When I witnessed all these, I really pitied the customer. The job was pressurizing, because the customers are mostly rich people. However, if a Christian waiter is met with the same situation, he would not do the same, he would not do the same to you just because you have offended him.

Research from Australia has found that managers and professionals regard spiritual self-disclosure as a taboo and a stigma, and risk being perceived by their colleagues as "being on the outer"-marginalized from the social, cultural, and spiritual identity of the organization (Crossman 2015). Such sentiments are shared by many respondents who regard themselves as qualitatively different from their non-Christian colleagues. For them, religious self-disclosure and expressions in the workplace can be simultaneously uplifting and challenging. For Andy, the IT specialist, this sense of being different was supported by his Christian principles and "proper outlook". As he shares, "I feel that faith has allowed me to have a proper outlook of the world. I will have my principles and not drift about in the world. I know how to do the right things. For work, I feel the need to do things in a principled manner, and to put in my best effort".

According to Wang, a doctor based in Kunming, in his previous work in the hospital he sometimes felt his colleagues regarded him as a "different kind" (linglei), a term which might carry a deviant 
undertone, because his behavior and values often differed from theirs. Thus, the boundary between the Christians and non-Christians seems to be drawn not just by the Christians but also by the non-believers, in the workplace. As Wang notes, this supposed difference might have both positive and negative implications for workplace relations:

In the hospital I was the only Christian. From my actions and the things that I say, they would have guessed that I am different from them. Some were accepting and found nothing wrong with that. But some would hang out less with you, thinking that you are different from them. However, there were still some who felt that I was nice to hang out with as an individual, and sometimes felt a little curious which prompted them to interact with me more, to learn more about my religion. So there are differing attitudes from different groups of people.

When asked to elaborate on how being a Christian distinguished him from his colleagues, Wang emphasized that as much as possible he would make decisions "that are in accordance with Bible teachings". He was fortunate that his superior generally accepted his reasons for not doing things which contravened his religious principles. Wang gives an example whereby the hospital authorities directed the doctors to make fake diagnoses of patients and cases that did not exist, to improve the hospital's rankings by the health authorities. Wang explained to his supervisor that this contradicted his Christian values, but also indicated that he would contribute to the hospital in other ways. Fortunately, his superior saw that his attitude "was satisfactory" and "had trust in him", agreeing that he did not have to participate in the proposed scheme. This episode gave Wang the confidence "that there is power in religious belief". Anne, who works in the software industry in Shenzhen, partly attributes her positive work attitude to her faith, when encountering difficulties:

When I face difficulties at work, I often consult the Bible. Before, I might not know how to solve the problems. After I started believing in the Jesus, I have become more demanding towards my work, because I feel that I cannot be the same as others.

According to Hui Wen, a sales executive, Christian workers tended to be more accommodating and understanding:

Some non-Christians like to grumble and complain. For example, they might be dissatisfied when the boss gives the year-end bonus, saying that this year's bonus doesn't match last year's, or they will compare who gets more and less. But for us [Christians], we tend to be more understanding. I may feel that it's ok to have a bit less bonus, because business this year hasn't been good, and this is helpful for the boss's business. Or, when we encounter some minor problems, we will try to be more accommodating, and to touch others with our loving care. Some non-Christians have bad habits, after arriving they will first make coffee, surf the Internet, and start their work in the afternoon. We will focus on doing our job well first thing in the morning.

Thus, Christian employees often construct an identity boundary between themselves and non-Christian colleagues, via a moralistic discourse that portrays them as embodying "correct" and more "positive" values. At the same time, these were also the values that were deemed lacking in the workplace and the wider society. They believed that it was the difference in their work attitude and their values that allowed them to showcase their faith to their non-Christian colleagues, and to hopefully to create a work culture imbued with Christian ethics. For Christian workers who find themselves in a workplace with a predominantly Christian workforce, the sharing of a common religion is the single most important element that contributes to these workers' sense of workplace well-being. For Mary, who was previously working as an accountant in a state-owned enterprise before her current job teaching Chinese to foreigners in an international school, working in an environment where religion is taken seriously and openly expressed by colleagues, presents a huge contrast to her previous work 
experience. It is not that the Christian workplace is devoid of problems. However, sharing a common religion contributes significantly to a strong sense of bonding between colleagues. It also provides moral resources for the management and ordinary employees, to face difficulties together, in a more consensual and supportive way:

When you encounter difficult problems, you will be able to share them with sisters-in-Christ, and they will even join you in prayers as well. One will always encounter difficulties in life. Regardless of work or daily life, there are bounds to be trials that one must go through. I have been in this sector for about 10 years, there are many problems which we face every day. It does not mean that we as a Christian school do not encounter any problem. We too have our own problems, and some of them are not small either. But the biggest difference is that we will be able to find someone to share and to pray for you. The difficult thing is life is not about the obstacles we face, it is more about the support and encouragement that the people by your side provide.

Sharing a common religion might contribute to the building of trust, and hence facilitate the cultivation of socially and commercially beneficial relationships, with one's colleagues and business acquaintances. Hui Wen notes how her work performance has actually improved after she decided to focus more on her clients' needs instead on her sales figures. For her, this change in priority since becoming a Christian had unexpectedly improved her work performance. When clients experienced good and sincere service, many then introduced Hui Wen to their relatives and friends. To Simon, a Kunming-based teacher, Christians tend to be more trustworthy, compared to non-Christians. A Christian's ability to inspire trust (cf. Tong and Yang 2016) in others is good not only for sealing business deals but also for motivating workers and establishing collegial atmosphere in the workplace. When asked how important religious faith is in the workplace, Simon opines:

It's very important. First, it's trust. Because you will realise that in general among business people, many are not trustworthy. There are also many who want to get close to you through the faith. But to me, I might not interact with them often on a daily basis, but in times of real trouble, we are willing to help others, including in business. Workers may judge whether the company's boss, if he is profit-minded or really cares for the workers. While a company seeks profits, it should also look after the workers ... When one interacts with colleagues as a Christian, people will get along better, there is greater efficiency in discussing things.

A phrase that emerged constantly among Christian professionals is "witnessing for the faith" (wei xinyang zuo jianzheng) at the workplace. It is through the expression of faith in their daily life, in the workplace, that Christian employees often merge the 'religious' and the 'secular (shishu). Commenting on how Christians should not be just "Sunday Christians" but should be religious exemplars in the normal workaday, Andy argues that in this way Christians could evangelize to their colleagues:

Your church life is different. But, it doesn't mean we have to separate them, to the point that your Monday through Saturday is different from your Sunday. Why do you do that? Shouldn't your faith be a consistent route? ... But once more and more brothers and sisters realize that it is important to have faithful life even throughout the week, it would make such a difference in the sense that people began to look at our faith differently. They will not just think that you are the ones only do something special on Sundays, on all the other days you are the same as me. Maybe some of us are not as good as you. But now they see difference, they see these people they do live a different life. They don't try to please the boss, for example, they don't bribe others. And they come to work on time. They don't steal company's money, and they don't steal company's time. People normally may not steal money, but most people steal time. But these people [Christians] are solid. These people we need to respect. I think it would play a very significant role in evangelism, especially in Chinese culture. 
Like many young Christian professionals based in the cities, Wang, the doctor, did not come from a Christian family and was introduced to Christianity while a student in the university. He got baptized after graduation, and shared that his religious faith has been important factor behind his career choices. After a stint as a junior doctor in the hospitals, Wang decided to work for a foreign NGO which partnered the local government in providing medical care to the needy in Yunnan rural areas. When asked if one's religion and one's occupation should have a clear dividing line, Wang said, "I personally feel that religion and occupation do not have any clear division. I said that because my own religious belief has played a large role in my career choice". Why do these Chinese professionals desire to integrate faith and work, or more generally, seek to dissolve the distinction between the so-called 'religious' (zongjiao de) and the 'secular' (shisu de)? To answer this, we have to consider their view on the meaning of work.

\section{Transforming the Workplace, Transforming the Society: Work as "Service"}

I feel that, compared to when I just graduated, I understand more what I actually want in life, and how to do better in my job. The faith has really been a profound influence on me, and such deep influence also affects my subordinates. Yes ... just as how Jesus has influenced me, I influence my subordinates and those around me. (Yaqiong, Shenzhen)

Conversion to a new religion often brings about a sense of radical break with the past. One respondent says that her "thinking has changed" (sixiang gaibian le), while another mentions that Christianity can "broaden one's horizon" (shiye kaikuole). Wenming, a marketing executive in Kunming, shares how becoming a Christian has motivated him to aspire towards sanctity in accordance with biblical teachings, thus, affecting in a profound discontinuity with his past behavior:

After becoming a Christian, I felt that the Lord's intention was for us to be kind or perfect, to aspire toward sanctity ... Because these are wonderful things, I aspire to achieve these ... The Bible tells us, we must love one another. Maybe there is too much lacking and imperfection in my life, I have this wish to cultivate sanctity in my life according to what the Bible proclaims.

Zhiqing, a teacher, shares that one big difference between being a Christian and her previous irreligious life is that "there is something in life to look forward to and that there is more hope in life". She further elaborates:

We were always sad and dull previously. We brood about having lousy parents, lousy jobs, we felt that there was no meaning in life. However, after becoming a Christian, I feel that life is more fulfilling and become more hopeful (shenghuo geng you yiyi, geng you xiwang). I was able to gain different perspectives (buyiyang de quandian). I feel that your working attitude will change because of your own character, you will also become more proactive.

This sentiment of rupture and change featured prominently among the Chinese professionals, when they shared their views towards their work. First, the trope that was frequently mentioned by respondents in relation to work was "to serve" (shifeng). For them, work is not just a source of livelihood, but more importantly, it provides an opportunity to serve God and the society at large. James, a software engineer in Shenzhen, describes this transformation:

Before, we thought that we only work for ourselves. However, two weeks ago, we went to a seminar, the teacher mentioned that actually we are working full-time. Because we are working, so we are employees. So if we work well, put in our best effort, to help others along as we work, we also serving the Lord ... I used to have the attitude of only doing the best for myself. When I was doing too many things and got irritated, my attitude would be quite negative. But if you believe in the Lord, even though this negativity could still be present to some degree, I feel I am uplifted. In the beginning you can't handle the pressure from work, but now, this limit of yours can increase a little, and you can endure. 
Many respondents revealed how they, prior to embracing Christianity, usually viewed work as numbing, while often having to navigate poisonous workplace relations that sapped their morale and energy. Converting to Christianity has profoundly transformed their experience of work and the workplace. They shared about having acquired more positive attitude towards their work and their colleagues as they embraced a new outlook in life and made changes to their behavior. As Mary, the teacher, said, "it is the same when it comes to work, when you become more proactive, you will engage yourself to do more things. I feel that the biggest change is the attitude to dare to challenge things". This transformation of work attitude does not mean that there are no longer problems in the workplace for the Christian workers. For someone like Weixiong, who runs a private school, the conflict between one's work and religious principles often come to the fore in the conduct of business. Holding an executive position means he is concerned about his company's profit levels, for the "main goal of a business is profit, to make money". After becoming a Christian, Weixiong increasingly finds instances of conflict between his Christian values and business practices, and this conflict will not disappear. "Once you have this religious faith", he says, "you may encounter different tests and seductions, and you will use some Christian standards as basis of your judgement".

In fact, being a Christian in a predominantly non-religious or even atheistic environment can result in ostracization, marginalization, and attracting unwanted attention. As discussed before, Christian employees might feel that they are regarded by their non-Christian colleagues, sometimes negatively, as of a "different kind" (linglei). In a society where Christians still constitute a small minority, and where there is still a lingering view among some Chinese people that Christianity is a "Western" and "foreign" religion, Christian employees constantly face the dilemma between the desire to express more openly their religious identity in the workplace and the need to downplay, or even hide, their religious faith in a largely non-Christian environment. At the same time, Christian employees tend to interpret their desire to inspire a more positive mind-set among colleagues, as "providing witness" (zuo jianzheng) for their faith, and as "serving the Lord" (shifeng zhu). What does "service" and "to serve the Lord" entail? As James indicated above, service can involve helping one's colleagues and business acquaintances in need. More concretely, work as service entails bringing the right (i.e., Christian) values to the workplace. In a society where the cultivation of good personal relationship (gao guanxi), with one's superiors and acquaintances, is often essential for one's career advancement, Anne shares how she often emphasizes fairness, equality, and transparency in her work, while lamenting that these values are not usually found in the workplace:

Before, I had to conduct inspection, and felt that there should not be favoritism, and should treat everyone the same (yishi tongren)! It doesn't matter if you are a superior or a normal worker. This is a small matter, but I felt everyone should receive equal treatment. I strove for fairness, justice, and transparency.

For the Christian employees, by expressing and integrating faith and work, couched in terms of "service", they hoped to transform people's values, the work culture, and ultimately embed Christian values in the wider society (cf. Wielander 2009). For these evangelical Protestants, the view of work as service dissolved the boundary between the secular work/workplace and religious life. Their desire to "provide witness for the faith" in the workplace was motivated by what they perceived as the main problem in the contemporary society-the decline of morality. With the rapid social transformations accompanying China's transition to a market-oriented society, personal, and public morality have suffered. Many of our respondents worried that people are now overwhelmingly obsessed with the pursuit of personal gains and wealth. Simon, the Kunming teacher, opined:

After the reforms, people come to have differing views on many issues. But in general, people acknowledge the economy as the main driving force, and early on people were just focused on making money. But right now, even though people are generally more well-to-do and financially stable, their moral values have declined. From what I understand, young people nowadays also have some bad feelings about the society, and they do not have 
strong values to guide them. This has resulted in immoral acts happening within their circle, affecting themselves, their family, their career, which is definitely a negative impact on the society. And I am worried about that. Therefore, when people with Christian faith stand up in society, this will have positive impact, and I believe that society will then experience positive development.

For Christian employees then, the everyday work environment is where China's moral crisis manifests in stark terms, and where they feel motivated to act in ways that might bring about a moral transformation, little by little, relying on religious values to guide their behavior. As Weixiong notes, "Because we can provide witness for the faith during work, and even to spread the gospel, so I feel that it's very good, to be able to do one's work and the Lord's work". China is suffering from a moral crisis, and religion-Christianity in particular-is seen as a font of ethical principles to tackle widespread social ills. Adopting the view of religion as everyday practice, the Christian workers' discourse of work as "service", entails both being "servants" of God in the workplace and engaging in efforts to transform the society, thus, dissolving the conceptual distinction between the 'secular' and the 'religious'.

\section{"Subtle Infiltration": Social Media and Workplace Evangelism}

I have discussed above about the Christian employees' desire to be a role model in the workplace, in order to influence their colleagues with Christian values, and to shape workplace culture. The study's respondents stressed that they would refrain from open evangelism and prefer to influence their non-Christian colleagues in subtle ways. Apart from striving to be ethical employees, many respondents consider the social media as another important means for evangelism and spreading Christian values in the workplace. One of the most remarkable social trends in China in recent years is the explosion of internet usage (Herold and Marolt 2011). According to the China Internet Network Information Center (CNNIC), as of December 2015, there were 620 million mobile internet users in China, with around $90 \%$ of internet users using mobile phones to access the internet. The Internet and social networking sites are rapidly penetrating into all domains of Chinese social, cultural, economic, and political life. A commentator has observed that "many Chinese netizens would not distinguish between social media and the internet itself", such that "the Internet is social media and vice versa" (Crampton 2012). The use of social networking sites has become an integral part of our respondents' lives, including their religious pursuits. A typical example is Wen, a woman in her early twenties, who shared her baptism experience:

I posted my baptism pictures on $\mathrm{QQ}$, and everyone was able to view them, as I did not set any restrictions. Many of my former classmates asked me, what are you doing, because there was a certificate. I told them that I was baptized. Then they asked me why I needed to be baptized? What is baptism? I told them that it's a procedure to becoming a Christian. They then asked me why I believe in Christianity, you are a Chinese and you still believe in it? Two days after I saw the comment, I told them that this is my choice and they have to respect that. After that one friend told me that she hoped that I could bring her to Christianity as well.

Anne, from Shenzhen, used the phrase, "subtle infiltration" (shentou) to describe the preferred method: "I will be subtle in WeChat [Weixin], not to proclaim that I am a Christian in an outright manner ... This kind of influence, it's a little by little, and slowly seeps into your consciousness. Then, you will ask me one day, you believe in this, right? And when you ask about the story of Jesus, I can then tell you loudly his story". This method of subtle evangelism is possible on social media like WeChat because one's "friends" on the app include non-Christians. When someone posts some Christian content on WeChat, some non-Christians may become interested and respond to the post. Lily, a teacher in Kunming, describes how this subtle evangelism works:

There are also non-believers that are hidden somewhere in the group. One of them is actually a Buddhist. I feel that it is alright and it is actually very good. We can try to influence him 
with what we are doing. He might be thinking, 'let's see how long you all can last with this, it might just be a one-time thing for a short whole.' But in fact, we are going to do this for 10 over years. I do not know when he will convert and believe in God, but I will pray for him.

James, from Shenzhen, observes:

When some people share some good things, I will share them in my other networks, or I will "like" and "support" on WeChat. I always do such things. Others may not know I am a Christian, but will ask, do you believe in this? I will then tell them indirectly.

Some respondents underscored the need to be subtle in their evangelism in social media, to avoid "scaring" others away. As one noted, "Actually you want to share with them but you are worried that your evangelism will create negative feelings in them. If I am too keen, they will be frightened, and will be unwilling to come for activities. So don't be too straightforward, show concern for them bit by bit in their daily life, you can't rush things". While many respondents view social media positively for its potential to facilitate evangelism in the workplace, some express a more cautious attitude and highlight its limitations. For Andy, social media like WeChat and QQ are regarded more as an effective tool for communicating with friends, colleagues and family members in an environment where mobile phone usage is very widespread. He said, “To me, [these social media] are just a tool. I usually don't intentionally use QQ or WeChat to tell others about the gospel. Very little".

Partly due to their awareness of the political sensitivity of religion in China and partly due to their own personal preference for privacy, some respondents are more ambivalent about using social media as a means for evangelism among colleagues. There were also concerns that a more enthusiastic evangelism among one's circle of colleagues who are on one's social networking sites might put strain on friendship. Wang, when asked if he used social media to share religious material among friends and colleagues, expressed his concerns and how he was still trying to negotiate the travails of social media:

If I do have some thoughts and feelings, I may put them in the private domain, and will not necessarily share them with others. I want to avoid putting pressure on my non-Christian friends, and not let them think that I am evangelizing openly through social media. I don't quite like to do this, and in any case I want to maintain our friendship. They do know me and actually many friends know that I am a Christian, and I really treasure maintaining our relationship. But at the same time, I also hope that they will get to know about the faith. So, I am still exploring what's the appropriate way".

While Christian employees recognize social media as important tools for religious communication and practice in the workplace, they serve to complement, and would not replace, face-to-face interactions. Meanwhile, Christian employees assiduously avoid online discussion of "sensitive" and "political" issues, due to widespread perception of the ruling Communist Party's online surveillance and intolerance of dissent.

\section{Conclusions}

This study had two main aims. First, to uncover the core meaning Chinese Christian professionals attribute to the domain of work, how they practice faith integration in the workplace and the challenges they face in doing so. And second, to examine the issue of religion and social change in China. The research data showed that evangelical Protestant employees tended to view the society as experiencing a moral decline. This view, in turn, reinforced their sense of being different and legitimized their effort in changing society, through influencing their colleagues and changing the workplace culture. The study's significance was twofold: First, theoretically grounded on the concept of everyday religion, it shed light on how Chinese evangelical Protestants are able to practice their faith in a highly restrictive political context, by seeking faith integration in the workplace, outside the state circumscribed religious domain and surveillance of religious sites. At the individual level, this study found that SRW allows these Christians to strive towards the ideal 
of expressing their faith more holistically, and in turn, reinforces the religious values that form the basis of their ethical system (Giacolone and Jurkiewicz 2003). However, there are challenges. Chinese Christian employees' merging of religion, work, and other aspects of their daily life happens in a socio-political context, where Christians still constitute a small religious minority, and where Christianity can still be deemed a highly sensitive cultural and political issue, by many believers and non-believers alike. Given the current focus on Chinese Christian entrepreneurs in the scholarly literature, one of the questions the study sought to answer was whether the experiences of the Christian employees were similar to, or different from, that of the entrepreneurs. The study's findings suggest an important commonality-many, in both groups, strive to spread the gospel to non-Christians in the workplace and the wider society, and wish to express their religious faith more openly in their work life. This is not surprising, given that the two groups are broadly evangelical in their religious orientation and are embedded in similar political and societal context. There are, however, important differences. Compared to the Christian employees, the Chinese Christian bosses and entrepreneurs are much more capable of shaping the workplace culture to make it more "Christian". Many are also able to proselytize, to varying degree of success, among the employees who work for them. Additionally, some highly successful Christian entrepreneurs are able to rely on their wealth, influence, and high social status to work closely with government officials and agencies in their philanthropic, charitable, and "developmental" activities. However, this is not the case for Christian employees.

In relation to the broader scholarship on SRW in which some have argued for deeper integration of religion, spirituality, and the workplace, for its supposed benefits, this study's findings suggest that it is very unlikely to be implemented in China's political context. Evangelical Christian employees in China do not expect or demand their firms to create conducive environment for them to practice faith-work integration. Neither are they relying on the government to sympathize with, or accept, their strongly held view that religion should not be confined to a narrowly demarcated 'religious sphere' (zongjiao jie). These Christian professionals are not engaging in 'political merit-making' (Weller et al. 2017) by cultivating favorable ties with party-state officials, for their social engagement. Rather, they are both aware and wary of the wider socio-political context, as they seek to practice religion in their everyday life in a more encompassing manner, including in the workplace.

At the individual level, this study found that evangelical Protestant employees often discursively construct a boundary between themselves and the non-Christians, in the workplace, where they regard themselves as more motivated and understanding, having a more positive attitude toward work, and to be less corruptible. This discursive, self-othering is double-edged. On the one hand it enables the Christians to construct a distinctive workplace and social identity, one that is framed in religious terms. On the other hand, this risks resulting in their being negatively seen by non-Christian colleagues as belonging to a "different kind" (linglei), thus, accentuating the social gulf and tension that might have already existed between the Christian and the non-Christian employees. While Christian employees might strive to be role models in the workplace, many are also aware of the need to remain "subtle" in expressing and propagating their faith. One "subtle" way of doing so, is through the use of social media. In other words, in a broader restrictive political and cultural environment, they constantly experience a tension between their strong desire to express their faith more openly and the need to sometimes avoid explicit religious expressions in the workplace.

The second significant contribution of this study relates to the issue of religion and social change in China. In this study, I highlighted the need to examine religious social engagement outside the domain of civil society, to understand how religious actors might circumvent or ignore institutional boundaries and state regulations, while striving to make positive impacts on society. Social change, in the context of this study and as expressed by the respondents, entails the moral transformation of the society. For the respondents, this would involve the transformation of the workplace. Put in another way, they consider the transformation of the workplace to be a part of their effort to transform the society, in accordance with Christian values. From their evangelical standpoint, the ultimate aim is the Christianization of China. 
Some might question whether the lack of a more direct effort to change social structures, or of a more explicitly expressed political vision on the part of the Christian employees, could be regarded as social change. My rejoinder is that one of the main aims of this paper was to broaden our conception of social change and social engagement. I have argued for the need to pay attention to what the literature describes as unobtrusive social engagement. The Christian employees' attempt to change the moral climate of the workplace and then that of the society represents an effort, in a relatively unobtrusive manner (especially in the political climate of China), to change society in the long run. This attempt is based on a religious vision, often without explicitly referencing the 'political' as commonly understood. One reason is that, for these Christians, the 'political' is already subsumed under or encompassed by their religious vision.

Unlike the intellectuals in the literature on 'culture Christians' who engaged in theological and theoretical debates over Christianity's role in China's social and moral transformation, these Chinese evangelical Protestant employees are engaging in unobtrusive social engagement, through the practice of Christianity as an everyday or lived religion, with the aim of effecting social change. As employees, how do Protestant Christians seek to transform workplace culture, and thence the larger society, in a social context where they are the minority, and in a political context with highly restrictive religious regulations and with Christianity often viewed with suspect? The study's respondents eschewed the overt Christian mobilization and activism in civil society, as documented in some existing studies. Their perception and experience of moral decline in society motivates them to seek moral and social transformation, not by open advocacy through civil society activism, but through influencing their colleagues and workplace culture. Many respondents consider their work to be a means for social transformation viewed in moral terms. For them, the workplace is an arena where Christian evangelism, the perceived moral decline of contemporary society, and the supposed solution to the crisis are entangled, allowing for a distinct narrative and practice of Christian social engagement to emerge in China. Chinese evangelical Protestant employees rationalize this effort in terms of work, as a form of "service" - to God, to colleagues, and to society.

An important difference between China and the Faith at Work movement in the West is that the latter had emerged and flourished in social, political, and cultural contexts which were relatively favorable to religion (especially Christianity). Within China, unlike the Christian entrepreneurs or Wenzhou 'Boss Christians' described in the literature, Christian employees in the country do not enjoy the relative freedom and authority to openly express their faith in the workplace. Neither are they able to demand their secular firms or appeal to the country's laws to support faith-work integration. In an authoritarian political context where civil society activism is curtailed, the workplace provides a relatively "safe" domain for Christian employees to engage in religious transformation of society, in less obtrusive and more subtle ways, outside the direct monitoring of the authorities. For these evangelical Protestant employees, the cultivation of personal piety and engaging in subtle proselytism in the workplace is not only a matter of saving souls, but also of transforming the moral fabric of society.

Funding: This research received no external funding.

Acknowledgments: I am grateful to my research collaborator, Sng Bee Bee, for her invaluable practical and substantive contributions to the research project. My sincere thanks go out to the respondents who have shared their views with us. Discussions with Shirley Sun have helped sharpen the analysis. The NTU New Silk Road Grant and the Ministry of Education AcRF Tier 1 Grant provided the funding that made this research possible. Last but not least, I am thankful to the two anonymous reviewers for their critical comments and helpful suggestions.

Conflicts of Interest: The author declares no conflicts of interest.

\section{References}

Ammerman, Nancy, ed. 2007. Everyday Religion. New York: Oxford University Press.

Benefiel, Margaret. 2005. The Second Half of the Journey: Spiritual Leadership for Organizational Transformation. The Leadership Quarterly 16: 723-47. [CrossRef] 
Bottero, Wendy. 2004. Class Identities and the Identity of Class. Sociology 38: 985-1003. [CrossRef]

Bourdieu, Pierre. 1987. Distinction: A Social Critique of the Judgement of Taste. Cambridge: Harvard University Press. Cao, Nanlai. 2013. Elite Christianity and Spiritual Nationalism. Chinese Sociological Review 45: 27-47. [CrossRef]

Chan, Kim-Kwong, and Tetsunao Yamamori. 2002. Holistic Entrepreneurs in China. A Handbook on the World Trade Organization and New Opportunities for Christians. Pasadena: William Carey International University Press.

Chen, Chin-Yi, and Chin-Fang Yang. 2012. The Impact of Spiritual Leadership on Organizational Citizenship Behavior: A Multi-sample Analysis. Journal of Business Ethics 105: 107-14. [CrossRef]

Chow, Alexander. 2018. Chinese Public Theology: Generational Shifts and Confucian Imagination in Chinese Christianity. Oxford: Oxford University Press.

Ci, Jiwei. 2009. The Moral Crisis in Post-Mao China: Prolegomenon to a Philosophical Analysis. Diogenes 221: 19-25.

Cochran, Clarke E. 2014. Religion in Public and Private Life. New York: Routledge. First published 1990.

Crampton, Thomas. 2012. Social Media in China: The Same, but Different. China Business Review, January 1.

Crossman, Joanna E. 2015. Being on the Outer: The Risks and Benefits of Spiritual Self-Disclosure in the Australian Workplace. Journal of Management \& Organization 21: 772-85.

Duchon, Denis, and Donde Ashmos Plowman. 2005. Nurturing the Spirit at Work: Impact on Work Unit Performance. The Leadership Quarterly 16: 807-33. [CrossRef]

Fernando, Mario. 2002. The Place of Self-Actualisation in Workplace Spirituality: Evidence from Sri Lanka. Culture and Religion 9: 233-49. [CrossRef]

Fisher, Gareth. 2017. Lay Buddhists and Moral Activism in Contemporary China. Review of Religion and Chinese Society 4: 247-70. [CrossRef]

Frey, Christiane. 2008. Beruf: Luther, Weber, Agamben. New German Critique 35: 35-56. [CrossRef]

Fry, Louis W., Laura L. Matherly, and J.-Robert Quimet. 2010. The Spiritual Leadership Balanced Scorecard Business Model: The Case of the Cordon-Bleu Tomasso Corporation. Journal of Management, Spirituality E Religion 7: 283-314.

Ghumman, Sonia, and Linda Jackson. 2010. The Downside of Religious Attire: The Muslim Headscarf and Expectations of Obtaining Employment. Journal of Organizational Behavior 31: 4-23. [CrossRef]

Giacolone, Robert A., and Carole L. Jurkiewicz. 2003. Toward a Science of Workplace Spirituality. In Handbook of Workplace Spirituality and Organizational Performance. Edited by Robert A. Giacolone and Carole L. Jurkewicz. Armonk: M.E. Sharpe, pp. 2-28.

González-González, Miguel. 2018. Reconciling Spirituality and Workplace: Towards a Balanced Proposal for Occupational Health. Journal of Religion and Health 57: 349-59. [CrossRef] [PubMed]

Gregory, Raymond F. 2011. Encountering Religion in the Workplace: The Legal Rights and Responsibilities of Workers and Employers. Ithaca: ILR Press.

Hall, David D., ed. 1997. Lived Religion in America: Toward a Theory of Practice. Princeton: Princeton University Press.

Hanafin, John J. 2002. Morality and the Market in China: Some Contemporary Views. Business Ethics Quarterly 12: 1-18. [CrossRef]

Herold, David K., and Peter Marolt, eds. 2011. Online Society in China. London and New York: Routledge.

Hicks, Douglas A. 2003. Religion and the Workplace: Pluralism, Spirituality, Leadership. Cambridge: Cambridge University Press.

Kamoche, Ken. 2012. Managing People 'Spiritually': A Bourdieusian Critique. Work, Employment E Society 26: 497-513.

Katzenstein, Mary F. 1990. Feminism within American Institutions: Unobtrusive Mobilization in the 1980s. Signs 16: 27-54. [CrossRef]

Klandermans, Bert. 1988. The Formation and Mobilization of Consensus. In From Structure to Action: Comparing Social Movement Research across Cultures. Edited by Bert Klandermans, Hanspeter Kriesi and Sidney G. Tarrow. Greenwich: JAI Press, pp. 173-96.

Koesel, Karrie J. 2014. China Patriotic Pentecostals. Review of Religion and Chinese Society 1: 131-55. [CrossRef]

Laliberté, André. 2011. Contemporary Issues in State-Religion Relations. In Chinese Religious Life. Edited by David A. Palmer, Glenn Shive and Philip L. Wikeri. New York: Oxford University Press, pp. 191-208.

Lamont, Michèle. 1992. Money, Morals and Manners: The Culture of the French and American Upper Middle Class. Chicago: University of Chicago Press. 
Lee, Kam-hon, Dennis McCann, and MaryAnn Ching Yuen. 2012. Christ and Business Culture. Hong Kong: Centre for the Study of Religion and Chinese Society.

Leung, Beatrice. 2005. China's Religious Freedom Policy: The Art of Managing Religious Activity. The China Quarterly 184: 894-913. [CrossRef]

Liang, Yongjia. 2014. Morality, Gift and Market: Communal Temple Restoration in Southwest China. The Asia Pacific Journal of Anthropology 15: 414-32. [CrossRef]

McCarthy, Susan K. 2013. Serving Society, Repurposing the State: Religious Charity and Resistance in China. The China Journal 70: 48-72. [CrossRef]

McGuire, Meredith B. 2008. Lived Religion: Faith and Practice in Everyday Life. Oxford: Oxford University Press.

Miller, David W. 2007. God at Work: The History and Promise of the Faith at Work Movement. New York: Oxford University Press.

Mitroff, Ian I., and Elizabeth A. Denton. 1999. A Spiritual Audit of Corporate America: A Hard Look at Spirituality, Religion, and Values in the Workplace. San Francisco: Jossey-Bass.

Mythen, Gabe, Sandra Walklate, and Fatima Khan. 2009. I'm a Muslim, but I'm Not a Terrorist: Victimization, Risk Identities and the Performance of Safety. British Journal of Criminology 49: 736-54. [CrossRef]

Osburg, John. 2013. Anxious Wealth: Money and Morality among China's New Rich. Stanford: Stanford University Press.

Pew Research Center. 2012. The Global Religious Landscape. Washington: Pew Research Center.

Sass, James S. 2000. Characterizing Organizational Spirituality: An Organizational Communication Culture Approach. Communication Studies 51: 195-207. [CrossRef]

Scheitle, Christopher P., and Elaine H. Ecklund. 2017. Examining the Effects of Exposure to Religion in the Workplace on Perceptions of Religious Discrimination. Review of Religious Research 59: 1-20. [CrossRef]

Schielke, Samuli, and Lisa Debevec, eds. 2012. Ordinary Lives and Grand Schemes: An Anthropology of Everyday Religion. Oxford: Berghahn Books.

Shue, Vivienne. 2011. The Political Economy of Compassion: China's 'Charity Supermarket' Saga. Journal of Contemporary China 20: 751-72. [CrossRef]

Sloane-White, Patricia. 2011. Working in the Islamic Economy: Sharia-ization and the Malaysian Workplace. Sojourn 26: 304-34. [CrossRef]

Stansbury, Jason. 2015. Moral Imagination as a Reformational Influence in the Workplace. Journal of Markets and Morality 18: 21-41.

Tam, T. T. Ngo, and Justine B. Quijada, eds. 2015. Atheist Secularism and Its Discontent. London: Palgrave Macmillan.

Tong, Joy. 2012. Overseas Chinese Christian Entrepreneurs in Modern China. London: Anthem Press.

Tong, Joy, and Fenggang Yang. 2016. Trust at Work: A Study on Faith and Trust of Protestant Entrepreneurs in China. Religions 7: 136. [CrossRef]

Wang, Aiming. 2001. The Nature and Purpose of Theological Reconstruction in the Chinese Church. Chinese Theological Review 15: 19-26.

Weller, Robert P., C. Julia Huang, Keping Wu, and Lizhu Fan. 2017. Religion and Charity: The Social Life of Goodness in Chinese Societies. Cambridge: Cambridge University Press.

Wickeri, Philip L. 2007. Reconstructing Christianity in China: K. H. Ting and the Chinese Church. Maryknoll: Orbis.

Wielander, Gerda. 2009. Bridging the Gap? An Investigation of Beijing Intellectual House Church Activities and Their implications for China's Democratization. Journal of Contemporary China 18: 849-64. [CrossRef]

Woodhead, Linda. 2013. New Forms of Public Religion: Spirituality in Global Civil Society. In Religion Beyond Its Private Role in Modern Society. Edited by Wim Hofstee and Arie van der Kooij. Leiden: Brill, pp. 29-52.

Wright, Teresa, and Teresa Zimmerman-Liu. 2013. Atheist Political Activists Turned Protestants: Religious Conversion among Chinese Dissidents. Journal of Church and State 57: 268-88. [CrossRef]

Wu, Keping. 2016. The Philanthropic Turn to Religions in Post-Mao China: Bureaucratization, Professionalization, and the Making of a Moral Subject. Modern China 43: 425-55. [CrossRef]

Yan, Yunxiang. 2014. The Moral Implications of Immorality: The Chinese Case for a New Anthropology of Morality. Journal of Religious Ethics 42: 460-93. [CrossRef]

Yang, Fenggang. 2006. The Red, Black, and Gray Markets of Religion in China. The Sociological Quarterly 47: 93-122. [CrossRef] 
Yang, Huilin. 2010. The Contextualization of Chinese Christian Theology and Its Main Concerns. In Christianity and Chinese Culture. Edited by Mikka Ruokanen and Paulos Huang. Grand Rapids: W.B. Eerdmans, pp. 197-204. Yao, Kevin X. 2011. Chinese Evangelicals and Social Concerns: A Historical and Comparative perspective. In After Imperialism Christian Identity in China and the Global Evangelical Movement. Edited by Richard R. Cook and David W. Pao. Eugene: Pickwick Publications, pp. 46-72.

(C) 2019 by the author. Licensee MDPI, Basel, Switzerland. This article is an open access article distributed under the terms and conditions of the Creative Commons Attribution (CC BY) license (http:// creativecommons.org/licenses/by/4.0/). 

MDPI

St. Alban-Anlage 66

4052 Basel

Switzerland

Tel. +41616837734

Fax +41 613028918

www.mdpi.com

Religions Editorial Office

E-mail: religions@mdpi.com

www.mdpi.com/journal/religions

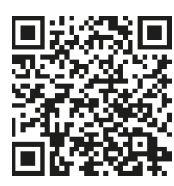



MDPI

St. Alban-Anlage 66

4052 Basel

Switzerland

Tel: +41 616837734

Fax: +41 613028918

www.mdpi.com 